DANMARKS GEOLOGISKE UNDERSØGELSE · SERIE A · NR. 17 MILJØMINISTERIET · Geological Survey of Denmark

\title{
Lower Cretaceous dinoflagellate biostratigraphy in the Danish Central Trough
}

BY

CLAUS HEILMANN-CLAUSEN

CONTRIBUTOR:

TOVE BIRKELUND

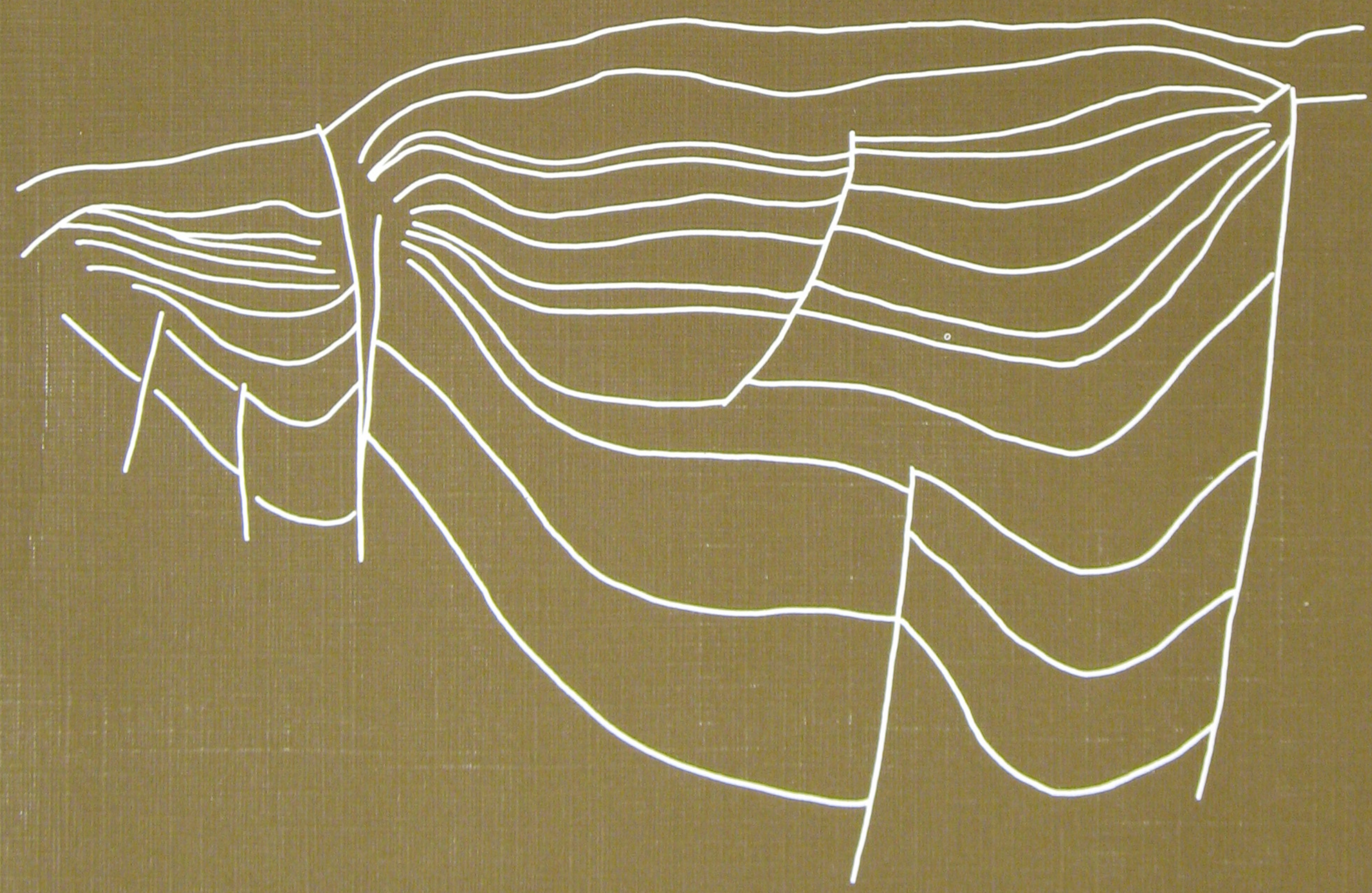

I kommission hos C. A. Reitzels forlag · København 1987 


\section{Lower Cretaceous dinoflagellate biostratigraphy in the Danish Central Trough} BY

CLAUS HEILMANN-CLAUSEN

with a contribution on the gottschei ammonite Zone (Hauterivian) in the Adda- 2 well by Tove Birkelund

I kommission hos C. A. Reitzels forlag · København 1987 


\section{A contribution to \\ EFP-83 project: \\ Jurassic-Lower Cretaceous stratigraphy \\ and basin development of the Danish North \\ Sea sector}

Key words:

Dinoflagellates, Lower Cretaceous,

biostratigraphy, North Sea, Northwest Europe.

Vignette:

East-west section through the Tail End Graben

DGU Serie A nr. 17

ISBN 87-421-0749-0

ISSN 0901-0270

Oplag: 1200

Tryk: AiO Tryk as, Odense

Tegning: Gitte Nicolaisen

Dato: 30-12-1987

Claus Heilmann-Clausen, Geological Institute,

Aarhus University, DK-8000 Århus C, Denmark

Redaktion: Leif Banke Rasmussen

(C) Danmarks Geologiske Undersøgelse,

Thoravej 8, DK-2400 København NV 


\section{Preface}

The present paper is one of several reports issued as the result of a research project carried out by the Geological Survey of Denmark in cooperation with the Geological Institute at the University of Copenhagen. The project has been financed by special contributions from the Ministry of Energy for the period from August 1st 1983 to December 31st 1986.

The project was entitled "Jurassic - Lower Cretaceous stratigraphy and basin development of the Danish North Sea sector". It has been decided to limit the study area to the Danish Central Trough, and effort has been concentrated on the Middle Jurassic, Upper Jurassic, and Lower Cretaceous.

The scope of the project was to coordinate analyses of the stratigraphy, facies development and burial history in order to create a basis for predicting possible occurrences of reservoir rocks. The following reports haver been printed in 1986 .

Frandsen, N.: Middle Jurassic deltaic and coastal deposits in the Lulu-1 well of the Danish Central Trough. Danm. geol. Unders., Ser. A, 9.

Hoelstad, T.: Palynology of the Middle Jurassic Lower Graben Sand Formation of the U-1 well, Danish Central Trough. Danm. geol. Unders., Ser. A, 14.

Hoelstad, T.: Palynology and palynofacies analyses of the Middle Jurassic to Lower Cretaceous in the Daish Central Trough. Danm. geol. Unders., Internal report.
Jensen, T.F., Holm, L., Frandsen, N. \& Michelsen, O.: Jurassic - Lower Cretaceous lithostratigraphic nomenclature for the Danish Central Trough. Danm. geol. Unders., Ser. A, 12.

Møller, J.J.: Seismic structural mapping of the Middle and Upper Jurassic in the Danish Central Trough. Danm. geol. Unders., Ser. A, 13.

Vejbæk, O.V.: Seismic stratigraphy of the Lower Cretaceous in the Danish Central Trough. Danm. geol. Unders., Ser. A, 11.

The following reports (including the present one) will be issued in 1987:

Heilmann-Clausen, C.: Lower Cretaceous dinoflagellate biostratigraphy in the Danish Central Trough.

Michelsen, O., Frandsen, N., Holm, L., Jensen, T.F., Møller, J.J. \& Vejbæk, O.V.: Jurassic - Lower Cretaceous of the Danish Central Trough; - depositional environments, tectonism, and reservoirs.

Poulsen, N.: Callovian (Jurassic) to Ryazanian (Cretaceous) dinoflagellate biostratigraphy of the Danish Central Trough.

Thomsen, E.: Lower Cretaceous calcareous nannofossil biostratigraphy in the Danish Central Trough.

DGU, 30th November 1986

Olaf Michelsen 


\section{Contents}

Abstract ............................ 7

Introduction ........................ 8

Materials and methods.................... 10

Materials........................ 10

Preparation...................... 10

Interpretation................... 10

Dinoflagellate distribution in the Lower

Cretaceous of Northwest Europe........... 11

Chronostratigraphy of sections yielding

dinoflagellate information

Dinoflagellate records in the Lower

Cretaceous of Northwest Europe. .

Dinoflagellate analysis in the Danish Central

Trough and ammonites in the Adda- 2 well

18

23
The Adda -1 well $\ldots \ldots \ldots \ldots \ldots \ldots \ldots \ldots \ldots, 23$

The I-1 well ................... 28

The $\mathrm{M}-8$ well $\ldots \ldots \ldots \ldots \ldots \ldots \ldots \ldots \ldots, 34$

The V-1 well .................... 36

The E-1 well .................... 36

The Adda-2 well .................. 37

Correlation of the studied wells ............ 40

Chronostratigraphy.................. 40

Age of lithological and seismic units........ 40

11 Systematics........................ 44

Organic-walled microplankton ............ 44

Acknowledgements................... 52

Literature ........................ 53 


\section{Abstract}

This study deals with Lower Cretaceous biostratigraphy based on dinoflagellates in the Central Trough (Danish North Sea sector). The stratigraphical distribution in Northwestern Europe of the species used in the analysis is evaluated on the basis of the literature, and a dinoflagellate range chart for the Lower Cretaceous of Northwestern Europe is presented.

Two wells, Adda-1 and I-1, containing a complete marine Lower Cretaceous sequence, are biostratigraphically analysed, primarily on the basis of ditch cutting samples. All six Lower Cretaceous stages are identified and their probable positions in the wells are indicated. Additional sections which cover minor parts of the Lower Cretaceous are analysed in the wells M-8, V-1, E-1 and Adda-2 (mainly based on cores and sidewall cores).

The ammonite Simbirskites (Craspedodiscus) cf. gottschei, indicating the Hauterivian gottschei Zone, is described from the Adda-2 well.

The lithostratigraphical and seismic stratigraphical units of the Central Trough are dated within the framework of dinoflagellate and ammonite stratigraphy.

The dinoflagellate species are systematically documented in photographic plates with remarks concerning their identification where necessary. 


\section{Introduction}

This contribution to the project: "Jurassic - Lower Cretaceous stratigraphy and basin development of the Danish North Sea sector" deals with the biostrati- graphy, based on dinoflagellates, of the Lower Cretaceous in the Danish part of the North Sea Central Trough (figs. 1, 2).

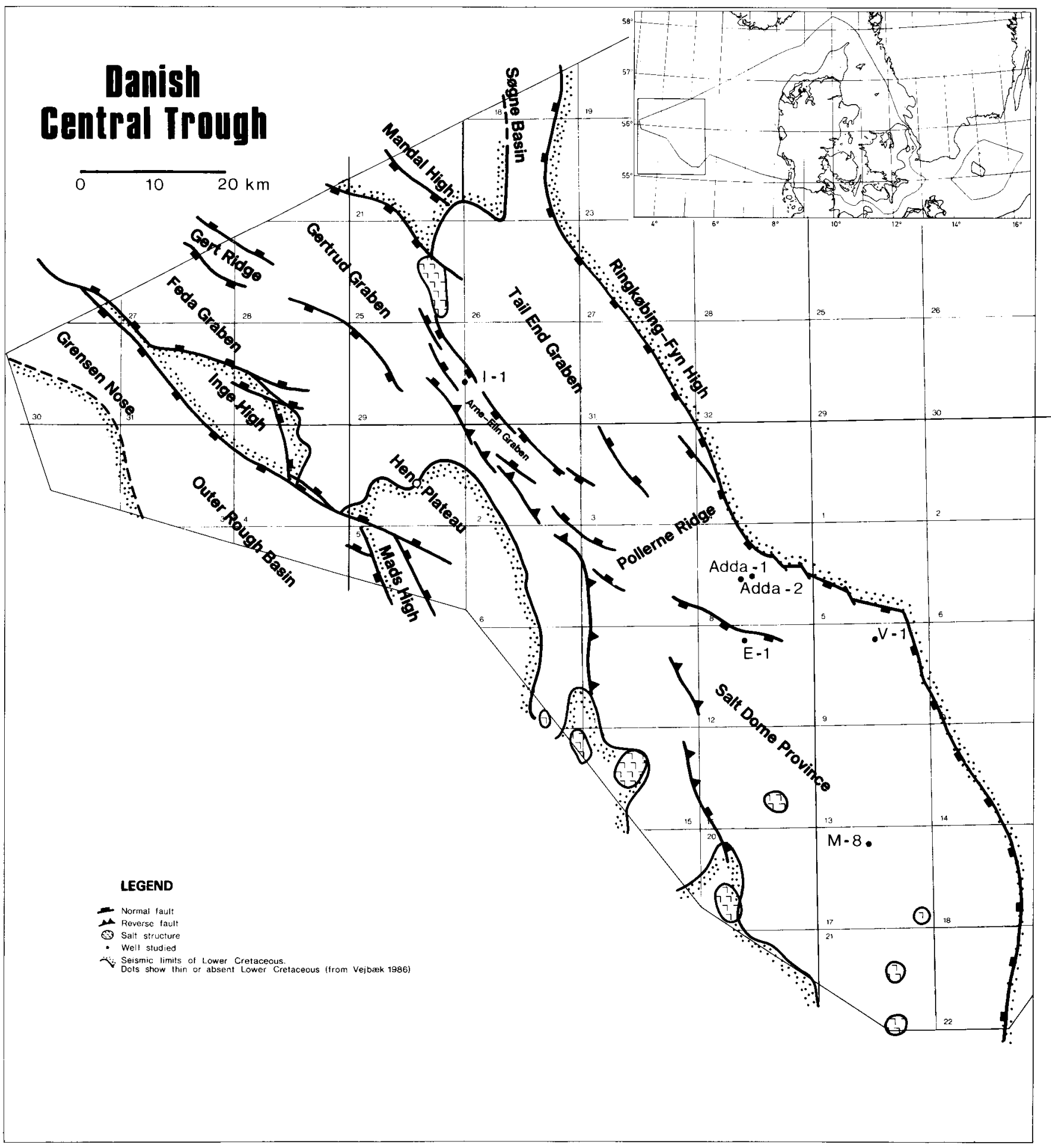

Fig. 1. Structural map of the Danish Central Trough showing location of the studied wells. 
Since the mid 1960s and especially in the last decade, it has become clear that dinoflagellates in the Lower Cretaceous deposits of Northwestern Europe are very useful age indicators. Dinoflagellates have proven useful for correlation and age-determination in the North Sea oil-exploration, and here they are probably the most widely used biostratigraphical tool in the marine Lower Cretaceous and Upper Jurassic.

The present contribution consists of three main parts.

The first part is an account of the stratigraphical occurrence of dinoflagellate species in Northwestern Europe. A distribution chart is included in this part (fig. 4) and it forms a standard reference for age-determinations of the Central Trough material.

In the second part an analysis of the dinoflagellate content of the Adda- 1 and I- 1 wells is carried out and an age determination is presented. These two wells were selected because they are considered to contain the most complete Lower Cretaceous sections and because of their typical development of the various lithological units. Dinoflagellate analyses of shorter sections from other wells are also presented. The facies distribution in the Central Trough is assessed in time and space on the basis of the biostratigraphy.

The third part documents the dinoflagellate assemblages, and most of the species found are figured in plates. Systematic remarks are given to some previously described species, as well as short descriptions of informally established forms.

Dinoflagellates are present in most of the lithological units of the Lower Cretaceous in the Central Trough, but the chalk and marl units in the upper part of the Lower Cretaceous sometimes proved to be barren of organic-walled microfossils. A biostratigraphical study of the calcareous nannoplankton was therefore carried out as part of this project (Thomsen in press).

Ammonites from a core of the Adda-2 well were

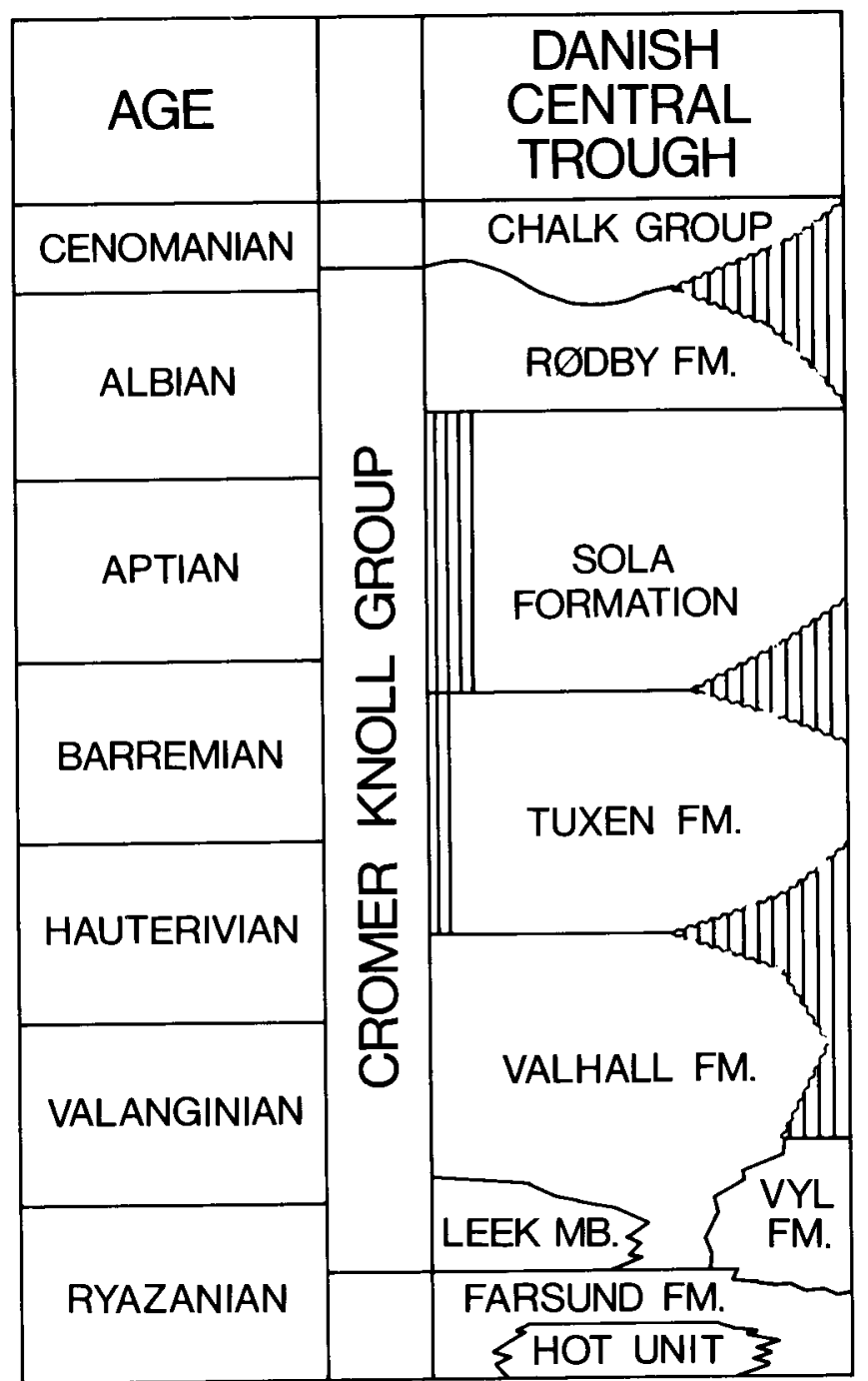

Fig. 2. Lithostratigraphical subdivision of the Lower Cretaceous deposits in the Danish Central Trough.

studied by the late Tove Birkelund and is included in the present volume. 


\section{Materials and methods}

\section{Materials}

Almost all of the North Sea samples used in this study are ditch cutting samples from North Sea exploration wells. Only a few short cored sections, and a small number of side-wall cores were available. Detailed information of sampled wells, depth and type of samples is given in the distribution charts. Depths of core samples are driller's depths. The locations of the wells examined are shown in Fig. 1.

Ditch cuttings for palynology were taken from the complete Lower Cretaceous intervals in the Adda-1 and I-1 wells. The sample spacing is variable so as to detect and localize as many biostratigraphical boundaries as possible. Samples are more closely spaced in the relatively condensed Barremian-Albian sequence than in the Ryazanian-Hauterivian interval.

Cores were palynologically sampled from the I-1, Adda- 2 and E-1 wells. Side-wall cores were sampled from the Adda-1, M- 8 and V-1 wells. A few cutting samples from the E-1 and V-1 wells were also analysed.

In addition to the North Sea material, sixteen outcrop samples were collected from the Lower Cretaceous Speeton Clay in Eastern England. The precise stratigraphical location of the samples is described in the following section, p. 18.

\section{Depository of material}

The palynological preparations are housed at the Geological Survey of Denmark where they are accessible for examination. Information on slide location of the figured dinoflagellates is available from the Geological Survey of Danmark or from the author.

\section{Preparation}

The samples were processed following a method developed by Hansen and Gudmundsson at the Danish Geological Survey. The method is described in detail by Gudmundsson (1985) and is briefly outlined here:

Acid treatment takes place in a container in which a number (usually 50-100) of samples are treated simultaneously. The samples are placed in bags made of polyester filter cloth with a mesh size of $10 \mu \mathrm{m}$. The bags are wrapped in foamy PVC for protection against mechanical damage. After acid treatment, filtration of the samples takes place by washing the bags in a household washing machine. The washing procedure effectively removes particles smaller than the mesh size of the sample bags. If a sample bag is damaged after washing it is noted on the slides prepared for microscopy so as to be aware of possible contamination from other samples.

\section{Interpretation}

The palynological preparations were studied using a transmitted light microscope.

The dinoflagellate assemblages in the cutting samples were usually contaminated by Tertiary species. This was also the case for samples taken after setting of casings in the Tertiary interval to prevent caving from this part of the well. Despite the fact that only washed cuttings were processed, the Tertiary contamination is believed to derive from drilling mud. Caving of certain Lower Cretaceous intervals could also influence the dinoflagellate assemblages in samples from deeper levels. However, since the age determinations were exclusively based on the last occurrence of species (first downhole appearance), contamination from caving and drilling mud was of minor importance.

More serious problems were encountered where the deposits have been resedimented by turbidity-currents or similar processes, especially in the Valanginian-Hauterivian interval. The use of first downhole appearance for age determination results in too old ages if the determination is based on reworked species. Reworked specimens may sometimes, but far from always, be detected by their different state of preservation. In this study species are regarded as reworked in cases when their first downhole occurrence is before the downhole appearance of younger species, i.e. when the successive downhole appearances of a suite of marker species are out of sequence. To detect reworking is therefore only possible when the true stratigraphical ranges of the individual species are known. The procedure is straightforward when dealing with reworking of much older sediments into younger (e.g. Jurassic into Hauterivian). It is more difficult, or even impossible, to detect reworking when the age difference is minor, as for example when Ryazanian is reworked into Valanginian. Close spacing of samples is therefore necessary in intervals with reworking, in order to pick as many first downhole occurrences as possible. Suspicion of reworking has been substantiated during the study by log-stratigraphical, sedimentological and geophysical information presented by Jensen et al. (1986) and Vejbæk (1986). 


\section{Dinoflagellate distribution in the Lower Cretaceous of Northwest Europe}

\section{Chronostratigraphy of sections yielding dinoflagellate information}

The existing literature of dinoflagellate stratigraphy in the Lower Cretaceous of Northwestern Europe is reviewed here to provide a reference for age determination of the North Sea material.

The stratigraphical distribution of dinoflagellates in Northwest Europe is well known today due to the large number of studies from independently dated sections that have been published in the last twenty years. Extensive dinoflagellate records are now available from almost all of the Boreal Lower Cretaceous ammonite zones. Exceptions to this are the Upper Valanginian and the lowermost Aptian (fissicostatus ammonite Zone), from which no, or only uncertain, dinoflagellate records exist.

No recent compilation of this large volume of data is available. Various range charts covering the Lower Cretaceous, or parts of it, have been published earlier, in particular by Davey \& Verdier (1973), Verdier (1975), Raynaud (1978), Duxbury (1978), Davey (1979c), Fisher \& Riley (1980) and Foucher (1981, 1983). Since these publications several papers have added new information, necessitating revision of the ranges and adding new species.

In order to compile the various dinoflagellate records, it was necessary first to correlate the sections yielding dinoflagellate information, and then to plot all relevant dinoflagellate records in a chronostratigraphical scheme. The correlation is based on the ammonite zonation of the sections. The sections yielding dinoflagellate records are shown in fig. 3 , and the dinoflagellate distribution chart in fig. 4 . In order to minimize the effect of palaeogeographical variation of the dinoflagellate ranges, only information from the Boreal Lower Cretaceous Province of Europe has been used in the dinoflagellate range chart.

The distribution of ammonites in the Lower Cretaceous of Northwestern Europe is probably better known than that of any other fossil group, and the modern Boreal ammonite zonation is the most reliable tool for correlation. The sections analysed for dinoflagellates have, in most cases, been studied previously by ammonite workers.

All sections have been arranged relative to the current ammonite zonation of the English Lower Cretaceous (Rawson et al. 1978). For convenient comparison with the important Speeton Clay Formation in Eastern
England an informal three-fold division of the Barremian Stage is used (again following Rawson et al. (1978)); thus the middle Barremian is typified by the Cement Beds (MB Beds) in the Speeton Clay Formation at Speeton.

The following two modifications of the scheme by Rawson et al. (1978) are made: 1. The Upper Valanginian is not well represented in England, and therefore the German Upper Valanginian ammonite zonation (Kemper et al. 1981) is used. 2. The Hauterivian-Barremian boundary was placed above the variabilis Zone in the scheme by Rawson et al. (1978). Following Kemper et al. (1981) this stage boundary is now placed below the variabilis Zone.

It should also be noted that the boundary between the Lower and Upper Aptian is placed above the bowerbanki Zone, following Casey's (1961) suggestions. In Thomsen (in press) the boundary is placed below the bowerbanki Zone.

French and German ammonite zonations are correlated with the English zones by Kemper et al. (1981), Amedro (1980), Rawson (1983) and Rawson et al. (1978). This permits approximate arrangement of the French and German dinoflagellate records in the English zonation scheme. Ammonite and dinoflagellate bearing strata are described from Sklinnabanken and Andøya in Norway by Birkelund et al. (1978) and Aarhus et al. (1986). Casey's (1973) correlation of Ryazanian ammonite zones in Europe and Siberia allows a correlation of the Norwegian ammonite occurrences with the English stenomphalus and albidum zones.

\section{The Jurassic-Cretaceous boundary}

This boundary is equal to the boundary between the Tithonian and Berriasian stages established in the Tethyan Province. In the Boreal Province the Jurassic-Cretaceous boundary has often been equalized with the Volgian-Ryazanian boundary, since a correlation to the Tethyan was formerly missing. Today an indirect, and therefore uncertain, correlation between the Tethyan and Boreal Province is possible near the Jurassic-Cretaceous boundary (see Casey 1973). It seems clear from the combined ammonite and ostracod evidence that the Jurassic-Cretaceous boundary (base of Berriasian) is below the base of the Ryazanian, and it may be located near the base of the Upper Volgian.

A number of papers presenting dinoflagellate data 


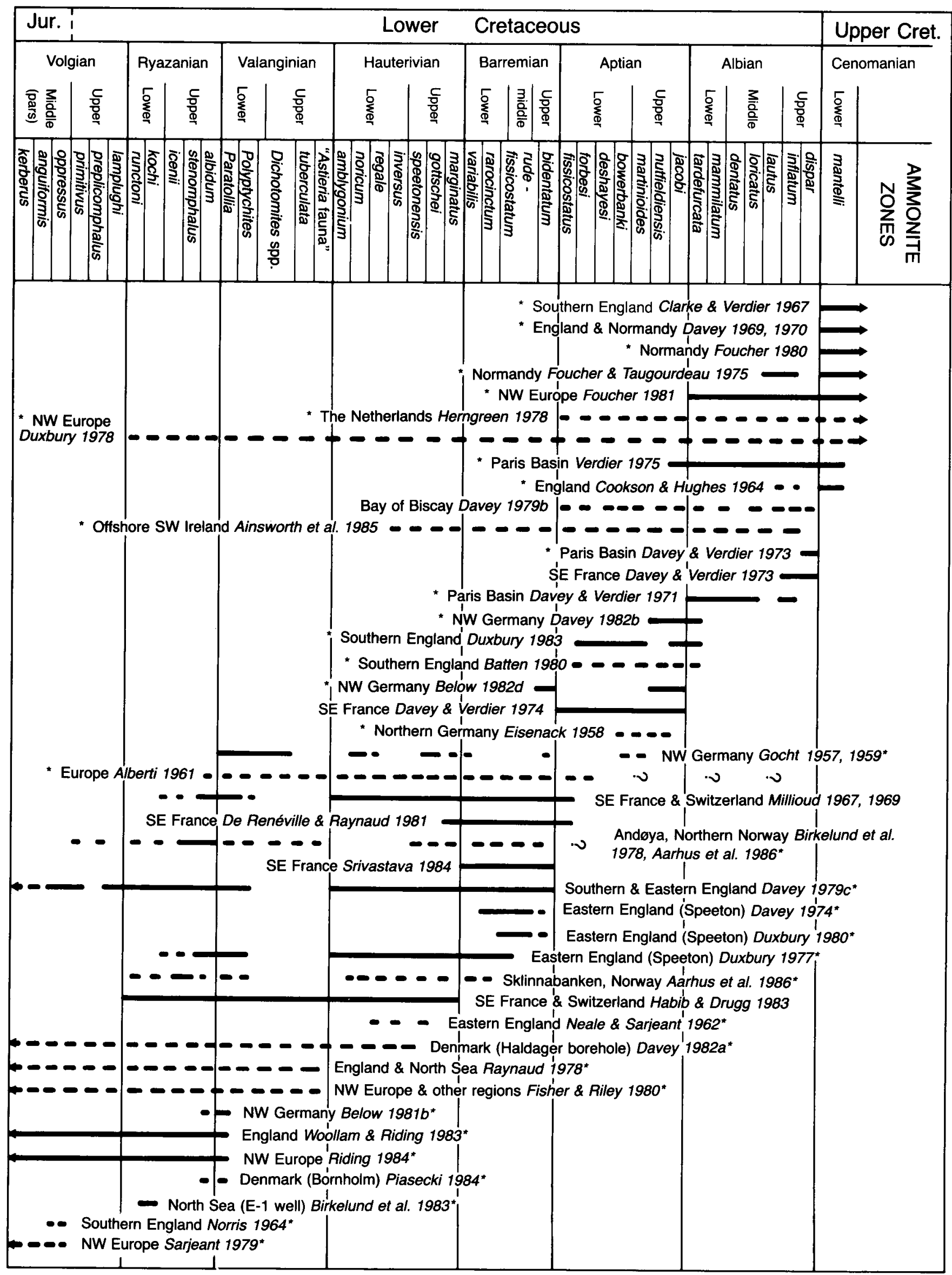

Fig. 3. Approximate stratigraphical coverage of most published dinoflagellate studies of the Lower Cretaceous in western Europe. The ammonite zonation is modified from Rawson et al. (1978) as explained in the text. Solid lines indicate palynological studies of ammonite-dated samples/sections. Dashed lines: studies giving no information on ammonites. Works from the Boreal Province are marked with an asterisk. 
needs some comment regarding the stratigraphical position of sections/samples studied, or concerning reworked dinoflagellate occurrences. These papers are commented below.

\section{Verdier (1975)}

Verdier (1975) presented a range chart of dinoflagellates from the Wissant section at Boulonnais, Northern France. Here the Cenomanian rests unconformably upon the Albian, with the uppermost Albian missing. According to Robaszynski et al. (1980) the basal Cenomanian is a glauconitic and conglomeratic basement bed to the Chalk. The dinoflagellate assemblage in the two Cenomanian samples studied by Verdier (1975) includes some species (see below) which are considered to be reworked.

\section{Davey $(1969,1970)$}

Mainly Cenomanian sections from England, France and North America were studied by Davey (1969, 1970). His lowermost samples 840 and CB 1 , just above the base of the Cenomanian, at Fetcham Mill and Compton Bay (Southern England) contain a number of dinoflagellates considered to be restricted to the Albian by Davey \& Verdier (1973: 209). These authors, in a discussion of Davey's $(1969,1970)$ results, threw some doubt on the Cenomanian age of the two samples. Judging from the presence of the ammonite Schloenbachia varians (see Davey \& Verdier 1973: 210) and the conglomeratic composition of this basal bed, the age is Early Cenomanian and the presence of Albian species is most likely due to reworking.

\section{Cookson \& Hughes (1964)}

The mid-Cretaceous section near Barrington (England) described by Cookson \& Hughes (1964) includes Albian sediments unconformably overlain by a less than 1 $m$ thick basal bed to the Chalk termed the Cambridge Greensand, and followed by the Lower Cenomanian Chalk Marl. Cookson \& Hughes (1964) placed the Cambridge Greensand, with some uncertainty, in the basal Cenomanian on the basis of ammonite evidence. According to Rawson et al. (1978: 50) the ammonite in question is Schloenbachia cf. varians subsp. subplana and of Cenomanian age.

Davey \& Verdier (1973) pointed out the strong Albian element in the Cambridge Greensand dinoflagellate assemblage recorded by Cookson \& Hughes (1964) and they threw doubt on the Cenomanian age.

The Cambridge Greensand is rich in reworked Upper Albian ammonites (Cookson \& Hughes 1964, Rawson et al. 1978) and it is thus very probable that the Albian dinoflagellates may be reworked.

\section{Below (1982d)}

An unconformity separates the Upper Aptian from the Upper Barremian in the "Otto Gott" clay pit section
(Northwest Germany) studied by Below (1982d). Several species occurring immediately above the unconformity have not previously been reported higher than the Barremian-Lower Aptian and they are considered as reworked.

\section{Duxbury (1983)}

The mainly Aptian section described from the Isle of Wight (Southern England) crosses the Aptian-Albian boundary (Casey 1961), but the ammonite data does not permit precise location of the boundary.

\section{Gocht $(1957,1959)$}

In this pioneer work on Lower Cretaceous dinoflagellates twelve samples of Valanginian-Barremian age from Northwestern Germany were studied, eleven of which were cores from boreholes. The ages of the samples and the dinoflagellates are summarized in Gocht (1959: 82-83). The ages are given by Gocht in terms of the contemporaneous German stratigraphical classification (e.g. Bartenstein \& Bettenstaedt 1962: 229). This classification is revised and correlated with the English ammonite zonation by Kemper (1971, 1973) and Kemper et al. (1981).

The samples of Gocht $(1957,1959)$ should probably be correlated with the English ammonite zonation as follows:

Sample 10

Sample 12

Sample 9

Sample 11

Samples 6, 7 \& 8

Samples 4 \& 5

Sample 3

Sample 2

Sample 1

Upper Barremian
gottschei/marginatus (or variabilis) Zones
gottschei Zone
regale Zone?
noricum Zone
Dichotomites spp. Zone
Polyptychites/Dichotomites Zones
Polyptychites Zone
Paratollia Zone

Alberti (1961)

The major study of Alberti (1961) includes Mesozoic (mainly Lower Cretaceous) and Lower Tertiary material from different parts of Europe and Asia. Many of the samples are from well-cores which cannot be precisely placed relative to the ammonite stratigraphy.

The Upper Aptian and Albian ages given for German samples yielding Pseudoceratium pelliferum (Alberti 1961: table opposite p. 44) have been doubted by Davey \& Verdier (1974: 650) and Duxbury (1983: 68). Particularly in the light of the works by Davey (1982b), Below (1982d) and Duxbury (1983) it seems highly unlikely that $P$. pelliferum should be present as high as Upper Aptian and Albian at the localities mentioned by Alberti, and the suggestion by Duxbury (1983) that these samples are of Early Aptian age is followed here.

\section{Davey (1982a)}

This work primarily deals with the dinoflagellates of the Volgian-Lower Hauterivian in the Danish Haldager 
Index of species in fig. 4

Achomosphaera? neptunii.................... 41

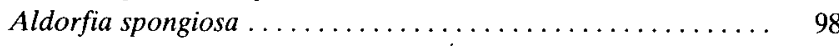

Aptea anaphrissa........................... 63

Aptea polymorpha .......................... 28

Aptea securigera ........................... 29

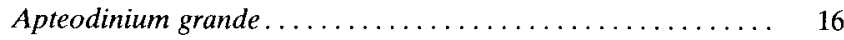

Ascodinium scabrosum ......................... 13

Avellodinium falsificum ....................... 61

Batioladinium longicornutum .................... 60

Batioladinium pomum ...................... 110

Batioladinium sp. I Davey 1982a..................... 109

Batioladinium varigranosum..................... 83

Batioladinium ef. varigranosum sensu Davey 1982a ....... 104

Callaiosphaeridium trycherium..................... 42

Canningia compta.......................... 100

Canningia cf. reticulata sensu Duxbury $1977 \ldots \ldots \ldots \ldots \ldots . . . \ldots 73$

Cannosphaeropsis thula ....................... 107

Carpodinium granulatum....................... 20

Carpodinium obliquicostatum................... 3

Cassiculosphaeridia magna ...................... 62

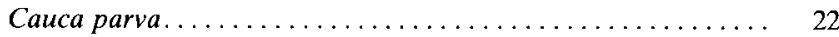

Cerbia tabulata .............................. 37

Chlamydophorella? membranoidea ................. 43

Chlamydophorella trabeculosa ....................... 49

Chytroeisphaeridia cerastes ......................... 95

Cribroperidinium boreas ....................... 54

Cribroperidinium? cornutum .................... 53

Cribroperidinium sepimentum ................... 67

Cribroperidinium sp. A Davey 1982 a ............... 113

Ctenidodinium elegantulum........................ 46

Ctenidodinium panneum ..................... 115

Cyclonephelium membraniphorum ................... 4

Cymososphaeridium validum ....................... 79

Diacanthum tenuiceras......................... 19

Dichadogonyaulax culmula....................... 108

Dingodinium cerviculum ....................... 34

Dingodinium spinosum ...................... 102

Diphasiosphaera stolidota ........................ 50

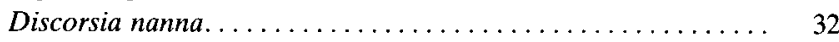

Egmontodinium expiratum ....................... 111

Egmontodinium polyplacophorum. ................. 114

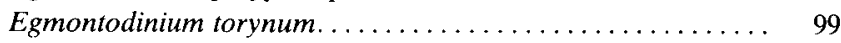

Ellipsodinium reticulatum $\ldots \ldots \ldots \ldots \ldots \ldots \ldots \ldots, \quad 52$

Ellipsodinium rugulosum...................... 6

Endoscrinium pharo........................ 97

Exiguisphaera phragma ...................... 77

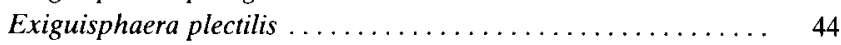

Fromea quadrugata............................ 55

Glossodinium dimorphum....................... 116

Gochteodinia villosa subsp. multifurcata $\ldots \ldots \ldots \ldots \ldots \ldots, 85$

Gochteodinia villosa subsp. villosa ................... 101

Gochteodinia virgula ........................ 112

Gonyaulacysta cassidata...................... 10

Gonyaulacysta cladophora sensu Duxbury $1977 \ldots \ldots \ldots \ldots . . .670$

Gonyaulacysta kostromiensis ................... 72

Gonyaulacysta ordocava ......................... 76

Gonyaulacysta? perforobtusa ...................... 74

Gonyaulacysta sp. A Davey 1982a ................ 106
Heslertonia heslertonensis ....................... 47

Hystrichodinium furcatum..................... 66

Hystrichodinium ramoides. ....................... 56

Hystrichosphaeridium arborispinum ................ 57

Hystrichosphaeridium scoriaceum ................ 78

Hystrichosphaerina schindewolfii................... 24

Isabelidinium gallium ......................... 15

Isthmocystis distincta $\ldots \ldots \ldots \ldots \ldots \ldots \ldots \ldots \ldots \ldots \ldots, \quad 86$

Kleithriasphaeridium corrugatum................. 69

Kleithriasphaeridium eoinodes .................... 23

Kleithriasphaeridium fasciatum.................... 71

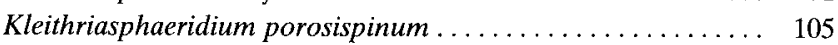

Kleithriasphaeridium $\mathrm{sp} .1 \ldots \ldots \ldots \ldots \ldots \ldots \ldots \ldots \ldots, 81$

Lagenorhytis delicatula ....................... 99

Leberidocysta chlamydata ........................ 2

Leptodinium cancellatum....................... 25

Litosphaeridium arundum.................... 18

Litosphaeridium conispinum................... 17

Litosphaeridium siphoniphorum ................. 1

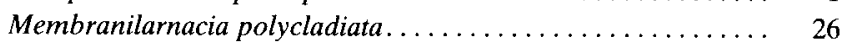

Muderongia extensiva........................ 82

Muderongia pariata ......................... 27

Muderongia simplex........................ 68

Muderongia simplex subsp. microperforata ........... 94

Muderongia staurota........................... 59

Muderongia tetracantha $\ldots \ldots \ldots \ldots \ldots \ldots \ldots \ldots \ldots \ldots, \quad 38$

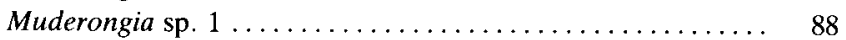

Nematosphaeropsis scala........................ 75

Occisucysta evittii .......................... 96

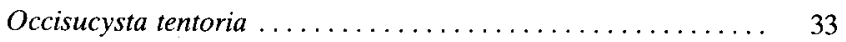

Odontochitina operculata...................... 9

Oligosphaeridium asterigerum .................. 39

Oligosphaeridium diluculum ....................., 103

Oligosphaeridium prolixispinum ................. 8

Phoberocysta neocomica ..................... 48

Phoberocysta tabulata .......................... 84

Prolixosphaeridium parvispinum .................. 14

Protoellipsodinium clavulum.................... 30

Protoellipsodinium spinosum ..................... 21

Psaligonyaulax deflandrei ....................... 5

Pseudoceratium pelliferum $\ldots \ldots \ldots \ldots \ldots \ldots \ldots \ldots \ldots \ldots, \quad 45$

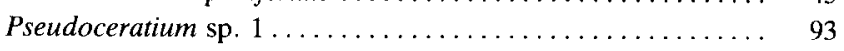

Rhynchodiniopsis aptiana ....................... 51

Sirmiodiniopsis frisia . . . . . . . . . . . . . . . . . . . 87

Sirmiodinium grossii......................... 36

Spiniferites? dentatus $\ldots \ldots \ldots \ldots \ldots \ldots \ldots \ldots \ldots \ldots \ldots \ldots, \quad 64$

Spiniferites ramosus .......................... 11

Spiniferites multibrevis...................... 12

Spiniferites ramosus subsp. primaevus ................ $\quad 80$

Stephodinium coronatum....................... 7

Stiphrosphaeridium anthophorum ................. 35

Stiphrosphaeridium dictyophorum................... 40

Subtilisphaera perlucida..................... 31

Surculosphaeridium sp. III Davey 1982a ............... 89

Systematophora palmula ....................... 92

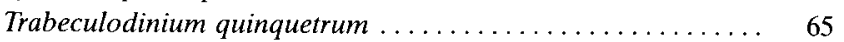

Trichodinium speetonense $\ldots \ldots \ldots \ldots \ldots \ldots \ldots \ldots \ldots \ldots \ldots, 58$

Tubotuberella apatela ....................... 90

Fig. 4. Recorded ranges of selected dinoflagellates in northwestern Europe. The ranges are based on the studies of Boreal European sections shown in fig. 3. Only species which occur in the Danish North Sea Sector are included in the range chart. Solid lines indicate records in ammonite-zoned sections. Dotted lines show records in sections without ammonite control, or uncertain identification of the dinoflagellate species. $R$ : probably reworked occurrence. Species considered the most reliable for correlation are marked with an asterisk. 


\begin{tabular}{|c|c|c|c|c|c|c|c|c|c|c|c|c|c|c|c|c|c|c|c|c|c|c|c|c|c|c|c|}
\hline Jur. & & & & & & & & & & Lor & wer & $\mathrm{C}$ & Cret & tac & eo & us & & & & & & & & & & & per Cret. \\
\hline Volg & & & & zan & ian & & Vala & ingin & hian & & taut & erivia & & & arre & mian & & & Apti & & & & & bian & & & nomanian \\
\hline 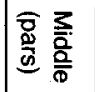 & $\mid \begin{array}{l}\text { 듕 } \\
\text { Ф }\end{array}$ & 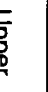 & ס్ & & 동 & & 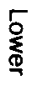 & & 宫 & & \} $&{ } &{\begin{array}{l}\text { 듐 } \\
\stackrel{0}{\prime}\end{array}} &{\text { 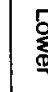 }} &{ } &{\begin{array}{l}\exists \\
\overline{\bar{z}} \\
\overline{\frac{2}{0}}\end{array}} &{ } &{ } &{\text { 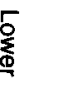 }} &{ } &{\text { 웜 }} &{\underset{\Phi}{\grave{\Phi}}} &{ } &{\text { 产 }} &{\begin{array}{l}\text { 등 } \\
\text { Ф }\end{array}} &{\text { Г్ }} &{ } \\
{\hline \text { 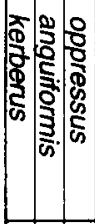 }} &{\text { 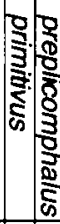 }} &{\text { : }} &{\text { 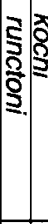 }} &{ } &{\text { 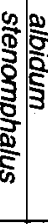 }} &{ } &{\text { 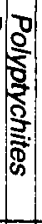 }} &{\text { 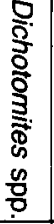 }} &{\text { 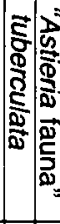 }} &{\begin{array}{l}3 \\
3 \\
3 \\
3 \\
3 \\
3 \\
3 \\
3 \\
3\end{array}} &{\text { 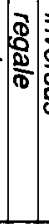 }} &{\text { 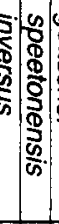 }} &{\text { 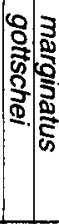 }} &{\begin{array}{l}5 \\
\vdots \\
0\end{array}} &{\text { 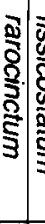 }} &{\text { 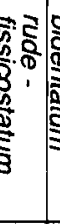 }} &{\text { 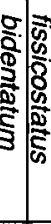 }} &{ } &{\text { 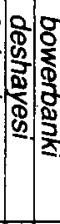 }} &{ } &{\text { 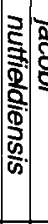 }} &{\text { 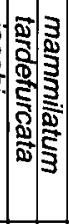 }} &{ } &{\text { 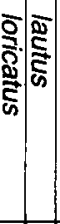 }} &{\text { 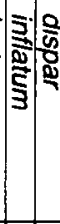 }} &{\text { 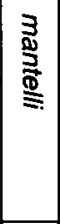 }} &{\text { 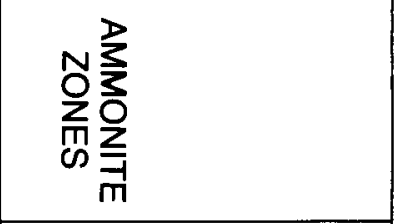 }} \\
{\hline} &{ } &{ } &{ } &{ } &{ } &{ } &{ } &{ } &{ } &{ } &{ } &{ } &{ } &{ } &{ } &{ } &{ } &{ } &{ } &{ } &{ } &{ } &{ } &{ } &{ } &{ } &{79 \text { Cymososphaerid. validum }} \\
{\hline} &{ } &{ } &{ } &{ } &{ } &{ } &{ } &{ } &{ } &{ } &{ } &{ } &{ } &{ } &{ } &{ } &{ } &{ } &{ } &{ } &{R} &{ } &{ } &{ } &{ } &{ } &{{ }^{\star} 80 \text { Spin. ramosus primaevus }} \\
{\hline} &{ } &{ } &{ } &{ } &{ } &{ } &{ } &{ } &{ } &{10} &{ } &{ } &{ } &{ } &{ } &{ } &{ } &{ } &{ } &{ } &{ } &{ } &{ } &{ } &{ } &{ } &{81 \text { Kleithriasphaerid. sp. } 1} \\
{\hline} &{ } &{ } &{ } &{ } &{ } &{ } &{ } &{ } &{ } &{\text { - }} &{ } &{ } &{ } &{ } &{ } &{ } &{ } &{ } &{ } &{ } &{ } &{ } &{ } &{ } &{ } &{ } &{\text { *82 Muderongia extensiva }} \\
{\hline} &{ } &{ } &{ } &{ } &{ } &{ } &{ } &{ } &{ } &{ } &{ } &{ } &{ } &{ } &{ } &{ } &{ } &{ } &{ } &{ } &{ } &{ } &{ } &{ } &{ } &{ } &{\text { *83 Batioladin. varigranosum }} \\
{\hline} &{ } &{ } &{ } &{ } &{ } &{ } &{ } &{\cdots} &{ } &{\text { E. }} &{ } &{ } &{ } &{ } &{ } &{ } &{ } &{ } &{ } &{ } &{ } &{ } &{ } &{ } &{ } &{ } &{\text { "84 Phoberocysta tabulata }} \\
{\hline} &{ } &{ } &{ } &{ } &{ } &{ } &{ } &{ } &{ } &{\text { - }} &{ } &{ } &{ } &{ } &{ } &{ } &{ } &{ } &{ } &{ } &{ } &{ } &{ } &{ } &{ } &{ } &{\text { *85 G. villosa multifurcata }} \\
{\hline} &{ } &{ } &{ } &{ } &{ } &{ } &{ } &{ } &{ } &{ } &{ } &{ } &{ } &{ } &{ } &{ } &{ } &{ } &{ } &{ } &{ } &{ } &{ } &{ } &{ } &{ } &{\text { "86 /sthmocystis distincta }} \\
{\hline} &{ } &{ } &{ } &{ } &{ } &{ } &{ } &{ } &{ } &{ } &{ } &{ } &{ } &{ } &{ } &{ } &{ } &{ } &{ } &{ } &{ } &{ } &{ } &{ } &{ } &{ } &{\text { *87 Sirmiodiniopsis frisia }} \\
{\hline} &{ } &{ } &{ } &{ } &{\cdot} &{ } &{\rightarrow} &{ } &{ } &{ } &{ } &{ } &{ } &{ } &{ } &{ } &{ } &{ } &{ } &{ } &{ } &{ } &{ } &{ } &{ } &{ } &{\text { "88 Muderongia sp. } 1} \\
{\hline} &{ } &{ } &{ } &{ } &{ } &{ } &{ } &{ } &{ } &{ } &{ } &{ } &{ } &{ } &{ } &{ } &{ } &{ } &{ } &{ } &{ } &{ } &{ } &{ } &{ } &{ } &{{ }^{\star} 89 \text { Surculosphaeridium sp. III }} \\
{\hline} &{ } &{ } &{ } &{ } &{ } &{ } &{ } &{ } &{ } &{ } &{ } &{ } &{ } &{ } &{ } &{ } &{ } &{ } &{ } &{ } &{ } &{ } &{ } &{ } &{ } &{ } &{\text { "90 Tubotuberella apatela }} \\
{\hline} &{ } &{ } &{ } &{ } &{\bullet} &{ } &{\text {. }} &{\cdots} &{\cdots} &{\bullet} &{ } &{ } &{ } &{ } &{ } &{ } &{ } &{ } &{ } &{ } &{ } &{ } &{ } &{ } &{ } &{ } &{\text { "91 Lagenorhytis delicatula }} \\
{\hline} &{ } &{ } &{ } &{ } &{ } &{ } &{0} &{\cdots} &{ } &{ } &{ } &{ } &{ } &{ } &{ } &{ } &{ } &{ } &{ } &{ } &{ } &{ } &{ } &{ } &{ } &{ } &{92 \text { Systematophora palmula }} \\
{\hline} &{ } &{ } &{ } &{ } &{\text { • }} &{ } &{\bullet} &{ } &{ } &{ } &{ } &{ } &{ } &{ } &{ } &{ } &{ } &{ } &{ } &{ } &{ } &{ } &{ } &{ } &{ } &{ } &{93 \text { Pseudoceratium sp. } 1} \\
{\hline} &{ } &{ } &{ } &{ } &{\cdot} &{ } &{ } &{ } &{ } &{ } &{ } &{ } &{ } &{ } &{ } &{ } &{ } &{ } &{ } &{ } &{ } &{ } &{ } &{ } &{ } &{ } &{94 \text { M. simplex microperforata }} \\
{\hline} &{ } &{ } &{ } &{ } &{ } &{ } &{ } &{ } &{ } &{ } &{ } &{ } &{ } &{ } &{ } &{ } &{ } &{ } &{ } &{ } &{ } &{ } &{ } &{ } &{ } &{ } &{95 \text { Chytroeisphaer. cerastes }} \\
{\hline} &{ } &{ } &{ } &{ } &{ } &{ } &{ } &{ } &{ } &{ } &{ } &{ } &{ } &{ } &{ } &{ } &{ } &{ } &{ } &{ } &{ } &{ } &{ } &{ } &{ } &{ } &{\text { *96 Occisucysta evittii }} \\
{\hline} &{ } &{ } &{ } &{ } &{ } &{\text { - }} &{ } &{ } &{ } &{ } &{ } &{ } &{ } &{ } &{ } &{ } &{ } &{ } &{ } &{ } &{ } &{ } &{ } &{ } &{ } &{ } &{\text { *97 Endoscrinium pharo }} \\
{\hline} &{ } &{\text { - }} &{ } &{ } &{ } &{[} &{ } &{ } &{ } &{.} &{ } &{ } &{ } &{ } &{ } &{ } &{ } &{ } &{ } &{ } &{ } &{ } &{ } &{ } &{ } &{ } &{\text { *98 Aldorfia spongiosa }} \\
{\hline} &{ } &{ } &{ } &{ } &{ } &{\bullet} &{ } &{ } &{ } &{ } &{ } &{ } &{ } &{ } &{ } &{ } &{ } &{ } &{ } &{ } &{ } &{ } &{ } &{ } &{ } &{ } &{{ }^{\star} 99 \text { Egmontodinium torynum }} \\
{\hline} &{ } &{ } &{ } &{ } &{ } &{ } &{\cdots} &{ } &{ } &{ } &{ } &{ } &{ } &{ } &{ } &{ } &{ } &{ } &{ } &{ } &{ } &{ } &{ } &{ } &{ } &{ } &{100 \text { Canningia compta }} \\
{\hline} &{ } &{ } &{ } &{ } &{ } &{ } &{ } &{ } &{ } &{ } &{ } &{ } &{ } &{ } &{ } &{ } &{ } &{ } &{ } &{ } &{ } &{ } &{ } &{ } &{ } &{ } &{\text { *101 Gochteod. villosa villosa }} \\
{\hline} &{ } &{ } &{ } &{ } &{ } &{ } &{ } &{ } &{ } &{ } &{ } &{ } &{ } &{ } &{ } &{ } &{ } &{ } &{ } &{ } &{ } &{ } &{ } &{ } &{ } &{ } &{\text { *102 Dingodinium spinosum }} \\
{\hline} &{ } &{ } &{ } &{ } &{ } &{ } &{ } &{ } &{ } &{ } &{ } &{ } &{ } &{ } &{ } &{ } &{ } &{ } &{ } &{ } &{ } &{ } &{ } &{ } &{ } &{ } &{103 \text { Oligosphaerid. diluculum }} \\
{\hline} &{ } &{ } &{ } &{ } &{ } &{\text { - }} &{ } &{ } &{ } &{ } &{ } &{ } &{ } &{ } &{ } &{ } &{ } &{ } &{ } &{ } &{ } &{ } &{ } &{ } &{ } &{ } &{\text { *104 Batiolad.cf.varigranosum }} \\
{\hline} &{ } &{ } &{ } &{ } &{ } &{ } &{ } &{ } &{ } &{ } &{ } &{ } &{ } &{ } &{ } &{ } &{ } &{ } &{ } &{ } &{ } &{ } &{ } &{ } &{ } &{ } &{\text { *105 Kleithriasp.porosispinum }} \\
{\hline} &{ } &{ } &{ } &{ } &{ } &{ } &{ } &{ } &{ } &{ } &{ } &{ } &{ } &{ } &{ } &{ } &{ } &{ } &{ } &{ } &{ } &{ } &{ } &{ } &{ } &{ } &{\text { *106 Gonyaulacysta sp. A }} \\
{\hline} &{ } &{ } &{ } &{ } &{\text {.. }} &{ } &{ } &{ } &{ } &{ } &{ } &{ } &{ } &{ } &{ } &{ } &{ } &{ } &{ } &{ } &{ } &{ } &{ } &{ } &{ } &{ } &{\text { "107 Cannosphaeropsis thula }} \\
{\hline} &{ } &{ } &{ } &{ } &{\text { •. }} &{ } &{ } &{ } &{ } &{ } &{ } &{ } &{ } &{ } &{ } &{ } &{ } &{ } &{ } &{ } &{ } &{ } &{ } &{ } &{ } &{ } &{\text {-108 Dichadogonyaulax culmula }} \\
{\hline} &{ } &{ } &{ } &{ } &{ } &{ } &{\text { 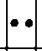 }} &{ } &{ } &{ } &{ } &{ } &{ } &{ } &{ } &{ } &{ } &{ } &{ } &{ } &{ } &{ } &{ } &{ } &{ } &{ } &{109 \text { Batioladinium sp. I Davey }} \\
{\hline} &{ } &{ } &{ } &{ } &{\bullet} &{ } &{ } &{ } &{ } &{ } &{ } &{ } &{ } &{ } &{ } &{ } &{ } &{ } &{ } &{ } &{ } &{ } &{ } &{ } &{ } &{ } &{\text { "110 Batioladinium pomum }} \\
{\hline} &{ } &{ } &{ } &{ } &{R} &{ } &{ } &{ } &{R} &{ } &{ } &{ } &{ } &{ } &{ } &{ } &{ } &{ } &{ } &{ } &{ } &{ } &{ } &{ } &{ } &{ } &{\text { *111 Egmontodinium expiratum }} \\
{\hline} &{ } &{ } &{ } &{ } &{ } &{ } &{ } &{ } &{ } &{ } &{ } &{ } &{ } &{ } &{ } &{ } &{ } &{ } &{ } &{ } &{ } &{ } &{ } &{ } &{ } &{ } &{\text { *112 Gochteodinia virgula }} \\
{\hline} &{ } &{ } &{ } &{ } &{ } &{ } &{ } &{ } &{ } &{ } &{ } &{ } &{ } &{ } &{ } &{ } &{ } &{ } &{ } &{ } &{ } &{ } &{ } &{ } &{ } &{ } &{\text { "113 Cribroperidinium sp. A }} \\
{\hline} &{ } &{ } &{ } &{\text { - }} &{\text { • }} &{ } &{ } &{ } &{ } &{ } &{ } &{ } &{ } &{ } &{ } &{ } &{ } &{ } &{ } &{ } &{ } &{ } &{ } &{ } &{ } &{ } &{\text { *114 Egmontodin polyplacoph. }} \\
{\hline} &{ } &{ } &{\text { 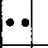 }} &{ } &{ } &{ } &{ } &{ } &{ } &{ } &{ } &{ } &{ } &{ } &{ } &{ } &{ } &{ } &{ } &{ } &{ } &{ } &{ } &{ } &{ } &{ } &{\text { *115 Ctenidodinium panneum }} \\
{\hline} &{ } &{ } &{ } &{ } &{ } &{ } &{ } &{ } &{ } &{ } &{ } &{ } &{ } &{ } &{ } &{ } &{ } &{ } &{ } &{ } &{ } &{ } &{ } &{ } &{ } &{ } &{\text { "116 Glossodinium dimorphum }} \\
{\hline} &{ } &{ } &{ } &{ } &{ } &{ } &{ } &{ } &{ } &{ } &{ } &{ } &{ } &{ } &{ } &{ } &{ } &{ } &{ } &{ } &{ } &{ } &{ } &{ } &{ } &{ } &{ } \\
$\hline
\end{tabular}

Fig. 4. continued 


\begin{tabular}{|c|c|c|c|c|c|c|c|c|c|c|c|c|c|c|c|c|c|c|c|c|c|c|c|c|c|c|c|c|c|}
\hline Jur. & & & & & & & & & & & on & ver & & Cre & ta & $\operatorname{cec}$ & ous & & & & & & & & & & & & oper Cret. \\
\hline Vols & gian & & Rya & azan & nian & & Vale & ingir & nian & & & aute & erivi & $\operatorname{ian}$ & & Barr & remia & & & & tian & & & & & jian & & & nomanian \\
\hline 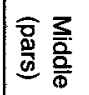 & $\frac{\subsetneq}{\frac{9}{0}}$ & & § & & $\frac{\text { 동 }}{\mathrm{D}}$ & & 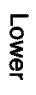 & & 등 & & & & & $\begin{array}{l}\text { 듬 } \\
\text { Ф9 }\end{array}$ & & 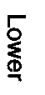 & $\mid \begin{array}{l}\bar{z} \\
\frac{\bar{a}}{\bar{\alpha}} \\
\frac{\bar{c}}{y}\end{array}$ & 窎 & & § & & $\begin{array}{l}\text { 듬 } \\
\text { क }\end{array}$ & & 市 & $\frac{3}{\overline{\overline{0}}}$ & & $\begin{array}{l}\text { 동 } \\
\text { 윽 }\end{array}$ & 占 & \\
\hline 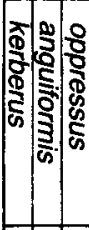 & 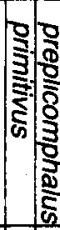 & & & & 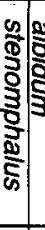 & & 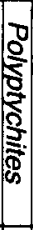 & 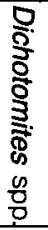 & 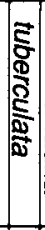 & & & 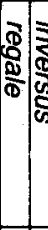 & 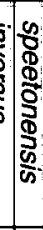 & 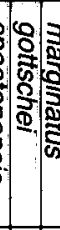 & & 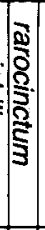 & 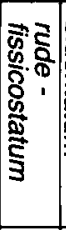 & 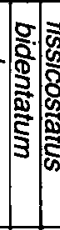 & 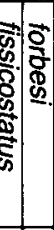 & $\begin{array}{l}0 \\
0 \\
0 \\
2 \\
2 \\
2 \\
8 \\
2 \\
2\end{array}$ & 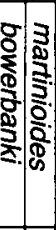 & $\frac{3}{3}$ & & 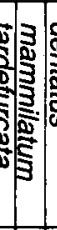 & के & & 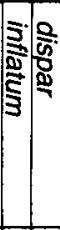 & $\frac{3}{\stackrel{3}{\overparen{2}}}$ & 次亭 \\
\hline & & & & & .. & & & & & & & & & & & & & & & & . & & & & & & & & 40 Stiphosphaer.dictyophor. \\
\hline & & & & & & & & & & & & & & & & & & & & & & 1 & & & & & & & *41 Achomosphaera? neptunii \\
\hline & & & & & & & & & & & & & & & & & - & & & & & - & & & & & & & *42 Callaiosphaer. trycherium \\
\hline & & & & & & & & & & & & & & & & & & & & & & H & & & & & & & 43 Chlamydophor. membranoidea \\
\hline & & & & & & & & & & & & & & & & & 7 & & & & & & & & & & & & *44 Exiguisphaera plectilis \\
\hline & & & & & & & & & & & & & & & & & & & & & & $\mathbf{R}$ & & & & & & & *45 Pseudoceratium pelliferum \\
\hline & & & & & & & & & & & & & & & & & & & & & & & & & & & & & *46 Ctenidodinium elegantulum \\
\hline & & & & & & & & & & & & & & & & & & & - & & & $R$ & & & & & & & *47 Heslertonia heslertonens. \\
\hline & & & & & & & & & & & & & & & & & & & F & & & & & & & & & & *48 Phoberocysta neocomica \\
\hline & & & & & & & & & & & & & & & & & & & - & & & $\ldots$ & & & & & & & 49 Chlamydophor.trabeculosa \\
\hline & & & & & & & & & & & & & & & & & & & $F$ & & & & & & & & & & *50 Diphasiosphaera stolidota \\
\hline & & & & & & & & & & & & & & & & & & & & & & & & & & & & & 51 Rhynchodiniopsis aptiana \\
\hline & & & & & & & & & & & & & & & & & & & & & & & & & & & & & 52 Ellipsodinium reticulatum \\
\hline & & & & & & & & & & & & & & & & & & & & & & & & & & & & & *53 Cribroperidinium cornutum \\
\hline & & & & & & & & & & & & & & & & & - & & & & & & & & & & & & 54 Cribroperidinium boreas \\
\hline & & & & & & & & & & & & & & & & & & & & & & & & & & & & & 55 Fromea quadrugata \\
\hline & & & & & & & & & & & & & & & & & - & & & & & & & & & & & & ${ }^{\star} 56$ Hystrichodinium ramoides \\
\hline & & & & & & & & & & & & & & & & & & & & & & & & & & & & & *57 Hystrichosph. arborispin. \\
\hline & & & & & & & & & & & & & & & & & & & & & & & & & & & & & 58 Trichodinium speetonense \\
\hline & & & & & & & & & & & & & & & & & & & & & & & & & & & & & *59 Muderongia staurota \\
\hline & & & & & & & & & & & - & & & & & & & & & & & & & & & & & & *60 Batiolad. longicornutum \\
\hline & & & & & & & & & & & & & & & & & & & & & & & & & & & & & "61 Avellodinium falsificum \\
\hline & & & & & & & & & & & & & & & & & & & & & & & & & & & & & *62 Cassiculosphaeridia mag. \\
\hline & & & & & & & & & & & & & & & & & & & & & & & & & & & & & *63 Aptea anaphrissa \\
\hline & & & & & & & & & & & & & & & & & - & & & & & $\mathrm{R}$ & & & & & & & 64 Spiniferites dentatus \\
\hline & & & & & & & & & & & & & & & & & - & & & & & & & & & & & & *65 Trabeculodin. quinquelat. \\
\hline & & & & & & & & & & & & & & & & & - & & & & & & & & & & & & *66 Hystrichodinium furcatum \\
\hline & & & & & & & & $\cdots$ & & & & & & & & & - & & & & & & & & & & & & 67 Cribroperidin. sepimentum \\
\hline & & & & & & & & & & & & & & & & & - & & & & & & & & & & & & *68 Muderogia simplex \\
\hline & & & & & & & & & $\ldots$ & & & & & & & & - & & & & & & & & & & & & *69 Kleithriasph. corrugatum \\
\hline & & & & & & & & & & & & & & & & & 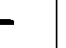 & & & & & & & & & & & & "70 G. cladophora s. Duxb.-77] \\
\hline & & & & & & & & & & & & & & & & & - & & & & & & & & & & & & ${ }^{\star} 71$ Kleithriasph. fasciatum \\
\hline & & & & & & & & & & & & & & & & & & & & & & & & & & & & & "72 Gonyaulac. kostromiensis \\
\hline & & & & & & & & & & & & & & & & & & & & & & & & & & & & & ${ }^{*} 73$ Canningia cf. reticulata \\
\hline & & & & & & & & & & & & & & & & & & & & & & & & & & & & & 74 Gonyaulac. perforobtusa \\
\hline & & & & & & & & & & & & & & & & & & & & & & & & & & & & & "75 Nematosphaeropsis scala \\
\hline & & & & & & & & & & & & & & & & & & & & & & & & & & & & & 76 Gonyaulacysta ordocava \\
\hline & & & & & & & & & & & & & & & & & & & & & & & & & & & & & "77 Exiguisphaera phragma \\
\hline & & & & & 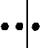 & & & & & & & & & & & & & & & & & & & & & & & & "78 Hystrichosph. scoriaceum \\
\hline
\end{tabular}

Fig. 4. continued 


\begin{tabular}{|c|c|c|c|c|c|c|c|c|c|c|c|c|c|c|c|c|c|c|c|c|c|c|}
\hline \begin{tabular}{|l|l} 
Jur. \\
\end{tabular} & & & & & & & & Lov & $\overline{e r}$ & Cre & ta & ceo & & & & & & & & & & pper Cret. \\
\hline Volg & & Rya & zania & & Valar & nginia & & & aute & ivian & & Barre & mian & & & tian & & & Albia & ian & & nomanian \\
\hline 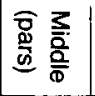 & $\begin{array}{l}\text { 돔 } \\
\text { 묵 }\end{array}$ & 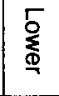 & $\begin{array}{l}\text { 돟 } \\
\text { 뭄 }\end{array}$ & & 点 & $\begin{array}{l}\text { 몸 } \\
\text { d }\end{array}$ & & a & & $\begin{array}{l}\text { 돔 } \\
\text { 뭄 }\end{array}$ & & & 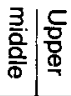 & & §్̊ & & 采 & & $\mid \begin{array}{l}\frac{3}{\bar{z}} \\
\frac{\overline{0}}{\overline{0}}\end{array}$ & $\mid \begin{array}{l}\text { 흥 } \\
\text { क }\end{array}$ & §్ & \\
\hline 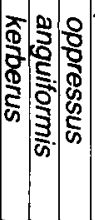 & 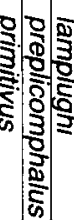 & $\mid$ & 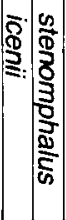 & 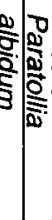 & 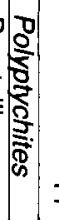 & 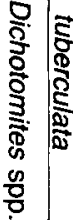 & 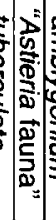 & & & 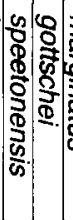 & & 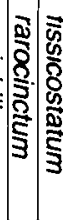 & 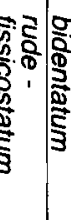 & & 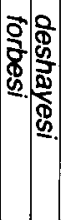 & & & 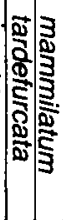 & 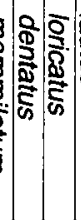 & 可 & 疋 & 为 \\
\hline & & & & & & & & & & & & & & & & & & & & & $\longrightarrow$ & * 1 Litosphaerid. siphoniphor. \\
\hline & & & & & & & & & & & & & & & & & & & & & $\rightarrow$ & * 2 Leberidocysta chlamydata \\
\hline & & & & & & & & & & & & & & & & & & & & & $\rightarrow$ & * 3 Carpodinium obliquicostat. \\
\hline & & & & & & & & & & & & & & & & & & & & & $\rightarrow$ & 4 Cyclonephelium memb. \\
\hline & & & & & & & & & & & & & & & & & & & & & $\rightarrow$ & * 5 Psaligonyaulax deflandrei \\
\hline & & & & & & & & & & & & & & & & & & & & & $\rightarrow$ & * 6 Ellipsodinium rugulosum \\
\hline & & & & & & & & & & & & & & & & & & & & & $\rightarrow$ & 7 Stephodinium coronatum \\
\hline & & & & & & & & & & & & & - & & & & & & & & $\rightarrow$ & 8 Oligosphaer. prolixispin. \\
\hline & & & & & & & & & & & & & & & & & & & & + & $\rightarrow$ & * 9 Odontochitina operculata \\
\hline & & & & & & & & & &.. & & & 二 & & - & & & & & & $\rightarrow$ & 10 Gonyaulacysta cassidata \\
\hline & & & $\cdot$ & & & & & & & & & & 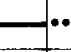 & & & & & & - & 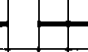 & $\rightarrow$ & *11 Spiniferites ramosus \\
\hline & & & & & H & & & & & & & & & & & & & & f & - & $\rightarrow$ & *12 Spiniferites multibrevis \\
\hline & & & & & & & & & & & & & & & & & & & & T & R & *13 Ascodinium scabrosum \\
\hline & & & & & & & & & & & & & & & & & & & & - & - & 14 Prolixosphaer. parvispin. \\
\hline & & & & & & & & & & & & & & & & & & & & F & $\mathrm{R}$ & *15 Isabelidinium gallium \\
\hline & & & & & & & & & & & & & & & & & & & & $\because-$ & $\mathrm{R}$ & *16 Apteodinium grande \\
\hline & & & & & & & & & & & & & & & & & & & & 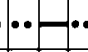 & $R$ & 17 Litosphaerid. conispinum \\
\hline & & & & & & & & & & & & & & & & & & & & - & & 18 Litosphaerid. arundum \\
\hline & & & & & & & & & & & & & & & & & & & & +1 & & 19 Diacanthum tenuiceras \\
\hline & & & & & & & & & & & & & & & & & & & & +1 & & "20 Carpodinium granulatum \\
\hline & & & & & H & & & & & & & & & & & & & & & +1 & & 21 Protoellipsodin. spinosum \\
\hline & & & & & & & & & & & & & - & & & & & - & 1 & \begin{tabular}{l|l}
$R$ & $F$ \\
\end{tabular} & $R$ & *22 Cauca parva \\
\hline & & & & & & & & & & & & & & & & & & -1 & R & & & *23 Kleithriasphaer. eoinodes \\
\hline & & & & & 15 & & & & & & & & & & & & & - & & & & 24 Hystr.sphaerina schindew. \\
\hline & & & & & & & & & & & & & & & & & & & & & & *25 Leptodinium cancellatum \\
\hline & & & & & & & & & & & & & & & & & & & & & & 26 Membranilarn. polycladiat. \\
\hline & & & & & & & & & & & & & 一 & & & & & & & & & *27 Muderongia pariata \\
\hline & & & & & & & & & & & & & & & & & & & & & & *28 Aptea polymorpha \\
\hline & & & & & & & & & & & & & & & & & & & & & & *29 Aptea securigera \\
\hline & & & & & & & & & & & & & & & & & & & & & & 30 Protoellipsodin. clavulum \\
\hline & & & & & & & & & & & & & & & & & & & & & & *31 Subtilisphaera perlucida \\
\hline & & & & & & & & & & & & & & & & & & & & & & *32 Discorsia nanna \\
\hline & & & & & & $\cdots$ & & & & & & & & & & & & & & & & 33 Occisucysta tentoria \\
\hline & & & & & & & & & & & & & & & & & & & & & & *34 Dingodinium cenviculum \\
\hline & & & & & & & & & & & & & 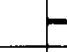 & 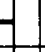 & & & & 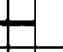 & & & & 35 Stiphrosphaer, anthophor. \\
\hline & & & & & & & & & & & & & & & & & & & & & & *36 Sirmiodinium grossii \\
\hline & & & & & & & & & & & & & 7 & & $\square$ & + & 7 & & & & & *37 Cerbia tabulata \\
\hline & & & & & $\bullet \cdot \bullet$ & & & & & & & & - & 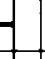 & & & & & & & & *38 Muderongia tetracantha \\
\hline & & & & & t & 二 & & & & & & 1 & - & $\theta$ & & & & & & & & 39 Oligosphaer. asterigerum \\
\hline
\end{tabular}

Fig. 4. continued 
No. 1 borehole, the ammonite stratigraphy of which is unknown. However much information is also given on dinoflagellate distribution in ammonite-dated VolgianEarly Cretaceous sediments from England.

Samples examined from the Speeton Clay

In addition to the published sources of information shown in fig. 3, samples from the following sixteen beds of the Speeton Clay at Speeton (Eastern England) were examined:

Barremian: Cement Beds (middle Barremian), Beds LB1, LB3, LB4 Hauterivian: Beds C3, C6, C8, C9, D1, D2D

Valanginian: Beds D3, D4

Ryazanian or Valanginian: Bed D5

Ryazanian: Beds D6H, D7G and E

The ammonite zonation of these beds is outlined and discussed by Rawson (1971), Casey (1973), Neale (1974) and Rawson et al. (1978).

\section{Dinoflagellate records in the Lower Cretaceous of Northwestern Europe}

The conclusive stratigraphical occurrence in Northwestern Europe of most of the species found in the present North Sea study is shown in fig. 4. The distribution chart is mainly based on the Northwest European studies shown in fig. 3. A few of the records are from the Speeton material examined in this study. The best species for age determination are marked with an asterisk. These are species which are easily identified and have recorded occurrences which are believed to approximate the true ranges in the Boreal province of Europe.

The occurrences of several species require comments which will be given in the following. The number after the species name refers to the position in the distribution chart (fig. 4); citation of authors to species names are given in the systematic section.

\section{Litosphaeridium siphoniphorum (1)}

The first well established occurrence in NW Europe is in the dispar Zone (Davey \& Verdier 1973). Verdier (1975) extended the range down into the inflatum Zone, but it is unclear whether this is based on observations in the Paris Basin or in the Tethyan of SE France.

\section{Odontochitina operculata (9)}

It is most probable that the earliest occurrence in Northwestern Europe is in the Lower Barremian where O. operculata is recorded by Davey $(1974,1979 \mathrm{c})$. Only one dubious pre-Barremian record exists (not included in the range chart), this is in Alberti (1961), who mentioned an uncertain occurrence in an Upper Hauterivian core.

The single specimen classified as $O$. operculata by
Gocht (1959) from the Upper Hauterivian or lowermost Barremian and figured in his pl. 6, fig. 12 is undoubtedly a Batioladinium longicornutum.

Gonyaulacysta cassidata (10)

The probable Hauterivian occurrence is based on the form described by Gocht (1959) as Gonyaulax? sp. 6.

\section{Spiniferites ramosus (11)}

S. ramosus subsp. primaevus is not included here, but is shown separately in the range chart.

The earliest occurrence of $S$. ramosus is an isolated record in the Ryazanian from Sklinnabanken, Norway (Aarhus et al. 1986). This occurrence is below a horizon yielding an ammonite marking the stenomphalus Zone. The lowermost Valanginian record of $S$. ramosus is in the Upper Platylenticeras-Beds in Northwest Germany (Below 1981b). The Valanginian record above this level is based on Davey (1979c), who may have included Spiniferites multibrevis (at that time classified as a subspecies of $S$. ramosus) in his concept of $S$. ramosus. The first specified occurrence of $S$. ramosus subsp. ramosus is in the basal Hauterivian (Duxbury 1977). The Lower Aptian record of $S$. ramosus is based on Duxbury (1983) and includes the specimens of his Spiniferites ramuliferus which show parasutural lines.

\section{Ascodinium scabrosum (13)}

The Cenomanian record of $A$. scabrosum is from Cookson \& Hughes (1964) and Davey $(1969,1970)$. In both cases $A$. scabrosum only occurs in the basal bed of the Cenomanian and is considered as reworked.

\section{Isabelidinium gallium (15)}

The single specimen recorded in the basal Cenomanian (Davey 1970) is considered to be reworked by Davey \& Verdier (1973), thus restricting the range to the uppermost Albian.

\section{Apteodinium grande (16)}

The Cenomanian records of this species are from Cookson \& Hughes (1964) and Foucher (1980). Cookson \& Hughes found $A$. grande in the basal bed of the Cenomanian, and Foucher (1980) recorded the species in his lowermost sample of the Lower Cenomanian where it is very rare. Both of these occurrences are most likely due reworking.

\section{Litosphaeridium conispinum (17)}

The only record of this species in the Cenomanian is by Verdier (1975) who considered the specimens as reworked. In the section studied by Cookson \& Hughes (1964) it is recorded in the Upper Albian but not in the Cenomanian (see discussion in Davey \& Verdier 1973: 208).

According to Davey \& Verdier (1973: 202) L. conispinum is absent in the dentatus Zone (Paris Basin 
Courchelles section), but present in the inflatum Zone (Paris Basin Vallentigny section) and becomes extinct at the top of this zone. This is in contrast to Verdier (1975) who showed the species also in the dispar Zone.

\section{Cauca parva (22)}

The Upper Albian - Lower Cenomanian records of this species are here regarded as probably reworked, as explained below.

C. parva was found by Verdier (1975) in the Lower Cenomanian at Boulonnais in Northern France but it was not recorded by Davey (1969) or Foucher (1980) in the Cenomanian at this site, or in the Cenomanian in England studied by Cookson \& Hughes (1964), Clarke \& Verdier (1967) and Davey $(1969,1970)$.

Likewise, C. parva was found in the Upper Albian at Boullonnais by Verdier (1975), but it was absent in the Upper Albian studied by Cookson \& Hughes (1964) and Davey \& Verdier (1971, 1973). The Upper AlbianLower Cenomanian occurrences at Boulonnais may therefore be reworked, as proposed by Verdier (1975).

C. parva is frequent in the lower Middle and Lower Albian of Northwestern Europe (Davey \& Verdier 1971, Davey 1982b, Verdier 1975). It occurs regularly in the Upper Aptian and is sporadic in the Lower Aptian on the Isle of Wight (Batten 1980, Duxbury 1983). It is common in the Upper Aptian in Northwest Germany (Davey 1982b, Below 1982d) and Boulonnais (Verdier 1975). It has been recorded by Duxbury (1980) in the middle and Upper Barremian at Speeton, but not by Davey (1974) working in the same section, and may therefore be rare in the Barremian. It was recorded by Below (1982d) in the Upper Barremian in NW Germany.

\section{Kleithriasphaeridium eoinodes (23)}

The single specimen recorded in the Middle Albian (Verdier 1975) is here considered reworked.

\section{Hystrichosphaerina schindewolfii (24)}

The Valanginian occurrence is based on the record in the Haldager No. 1 borehole in Denmark (Davey 1982a). This is the only pre-Barremian record of this species.

\section{Muderongia pariata (27)}

The figured specimen (Davey 1974: pl. 8, fig. 7, as $M$. staurota) from the middle Barremian at Speeton is here referred to $M$. pariata. This is the only pre-Aptian record of this species.

\section{Aptea securigera (29)}

The Upper Aptian forms classified as Cyclonephelium compactum ("extreme") by Duxbury (1983) are here included in Aptea securigera. A. securigera is also recorded in the Upper Aptian by Below (1982d).
Discorsia nanna (32)

The possible occurrence in the Upper Valanginian is based on Fisher \& Riley (1980).

\section{Dingodinium cerviculum (34)}

The record in the Upper Ryazanian stenomphalus Zone is based on occurrences at Sklinnabanken and Andøya, Norway (Aarhus et al. 1986), and the possible Jurassic occurrence is based on Fisher \& Riley (1980).

\section{Stiphrosphaeridium anthophorum (35)}

The occurrence in the kochi Zone (Ryazanian) is based on the specimen figured in Davey (1979: pl. 3, fig. 4) as Polystephanephorus sarjeantii (the identification of this species is commented on in the systematic part). The probable Volgian occurrence is from Sarjeant (1979).

\section{Sirmiodinium grossii (36)}

The last occurrence of $S$. grossii has previously been regarded as marking the top of the Barremian, e.g. by Verdier (1975) and Duxbury (1978), but no detailed study of the NW European Aptian had been carried out at that time. Since Duxbury's (1983) study of the dinoflagellate distribution in the Aptian from the Isle of Wight (Southern England) it seems clear that the last occurrence of $S$. grossii (and of two other equally distinct species, namely Pseudoceratium pelliferum and Phoberocysta neocomica, previously believed to be restricted to Barremian and older deposits) is within the Aptian - earliest Albian.

According to the distribution charts of Duxbury (1983) $S$. grossii is not frequent but is present in so many of the samples that it appears unlikely that it could be reworked. This view is supported by Below's (1982d) Upper Aptian record of $S$. grossii from Northwestern Germany.

The absence of $S$. grossii in the Tethyan Aptian sections from South-eastern France studied by Davey \& Verdier (1974) points to provincialism of this species during the Aptian.

\section{Muderongia tetracantha (38)}

Davey $(1979 \mathrm{c})$ and Below (1981b) both recorded $\mathrm{Mu}$ derongia crucis in the Lower Valanginian. This species is here considered as a junior synonym of Muderongia tetracantha, following Morgan (1980). The species was not figured by Davey (1979c) or Below (1981b), and it cannot be ruled out that their forms should instead be classified with Muderongia extensiva, since Duxbury (1977, working in the same section as Davey 1979) recorded $M$. extensiva in the Lower Valanginian and $M$. tetracantha only from the Upper Hauterivian-Lower Barremian. The only record of $M$. tetracantha above the Lower Barremian is by Below (1982d) and the species is therefore considered as more typical of the Hauterivian-Lower Barremian. 


\section{Stiphrosphaeridium dictyophorum (40)}

The Aptian occurrence is based on Eisenack (1958) and on the specimen figured in Davey (1982: pl. 6. 3-5, fig. 5) as Stiphrosphaeridium anthophorum (see discussion of $S$. dictyophorum in the Systematic Part). S. dictyophorum is present in a sample from bed D7G (stenomphalus Zone?) at Speeton (personal observation) whereas other Ryazanian records are from Davey (1982a) and Birkelund et al. (1983).

\section{Callaiosphaeridium trycherium (42)}

The Hauterivian and Lower Barremian records are in samples from beds LB4 and C6 in the Speeton Clay examined here.

\section{Pseudoceratium pelliferum (45)}

This species was recorded in samples of presumed Late Aptian and Albian ages by Alberti (1961). As discussed above, the age determination of these samples is believed to be erroneous.

A single sample out of thirteen from the nutfieldensis Zone studied by Below (1982d) yielded P. pelliferum. This occurrence is regarded as probably reworked.

See also comments to Sirmiodinium grossii (36).

\section{Ctenidodinium elegantulum (46)}

Typical specimens occur in bed D5 (uppermost Ryazanian?) at Speeton (this study).

\section{Heslertonia heslertonensis (47)}

Below's (1982d) record in one of the thirteen samples from the nutfieldensis Zone is regarded here as probably due to reworking.

\section{Phoberocysta neocomica (48)}

The exact first occurrence of this species is doubtful. In the range charts of Duxbury (1977) and Davey (1979c) the first occurrence is shown in the uppermost Ryazanian albidum Zone. However, both Duxbury (1977: e.g. pl. 14, fig. 10) and Davey (1979c) included specimens of a closely related species, Phoberocysta tabulata, in their concept of $P$. neocomica. Davey (1982a: 32) suggested that the earliest specimens recorded as $P$. neocomica in Davey (1979c) should instead be classified as $P$. tabulata. (For differentiation of the two species, see the systematic part).

Specimens seen in the present study from beds D5 and D4 at Speeton (?albidum - Paratollia Zones) belong to $P$. tabulata, while the earliest definitive $P$. neocomica is recorded in bed D3 (Polyptychites Zone).

Last occurrence: see comments to Sirmiodinium grossii (36).

\section{Chlamydophorella trabeculosa (49)}

The last occurrence of typical $C$. trabeculosa is in the Lower Aptian forbesi Zone on the Isle of Wight (Duxbury 1983). A somewhat different form occurs almost to the top of the Aptian (recorded by Duxbury 1983 as "Chlamydophorella nyei long-horned"). This form can apparently be distinguished by more stout processes, but otherwise is closely similar to $C$. trabeculosa.

Only records of typical $C$. trabeculosa are included in fig. 4. Gardodinium eisenacki in Batten (1980: pl. 1, fig. 1) is referred to Duxbury's "C. nyei long-horned".

Alberti (1961), Below (1982d) and Davey (1982b) recorded $C$. trabeculosa in their Upper Aptian material. They did not illustrate the specimens so they may possibly be identical to " $C$. nyei long-horned". The record based on these authors is therefore shown as uncertain in the range chart.

The probable Valanginian occurrence is based on remarks in Davey (1982a: 7).

\section{Diphasiosphaera stolidota (50)}

The earliest record is in the Upper Hauterivian (marginatus Zone, bed C3) at Speeton (this study).

\section{Rhynchodiniopsis aptiana (51)}

Following Below (1981a), the Barremian species Rhynchodiniopsis fimbriata is regarded as a junior synonym of $R$. aptiana. According to Deflandre (1935) the type specimen of $R$. aptiana is from an Aptian flint. However, the species appear to be more typical of the Barremian.

\section{Hystrichodinium ramoides (56)}

$H$. ramoides has previously been recorded from the Barremian. In the present study it is also found in the lowermost Hauterivian (amblygonium Zone, bed D2D) at Speeton. For differentiation of the closely related species Hystrichodinium furcatum, see the Systematic Part.

\section{Trichodinium speetonensis (58)}

This species, which is often difficult to distinguish from Trichodinium castanea, is recorded in the marginatus Zone (bed C3) at Speeton (this study).

\section{Spiniferites dentatus (64)}

Intermediate forms between Spiniferites dentatus and Spiniferites multibrevis occur in the Lower Valanginian at Speeton. Such forms are not included here.

The presumably reworked occurrence in the Aptian is a record from Below (1982d).

\section{Muderongia simplex (68)}

This species seems to be rare in the uppermost Hauterivian and Barremian. It was recorded by Duxbury $(1977,1978)$ from the Barremian at Speeton, but was not found above the Hauterivian by Davey (1979c) or the present author working in the same section. It is shown in Alberti's (1961) range chart from the Lower Aptian, but this record is questioned in his text (p. 12). 
Gonyaulacysta ordocava (76)

The earliest Valanginian record is from bed D4 at Speeton (this study).

\section{Exiguisphaera phragma (77)}

In addition to the occurrence in the Lower Hauterivian regale Zone at Speeton (Duxbury 1979) and in the lowermost Valanginian Paratollia Zone in Northwestern Germany (Below 1981b) this species is recorded in the present study from the Upper Ryazanian - lowermost Valanginian? beds D7G and D5 (?stenomphalus, albidum/Paratollia Zones) and the lowermost Hauterivian bed D2D (amblygonium Zone) at Speeton.

\section{Hystrichosphaeridium scoriaceum (78)}

This species is previously recorded only by Raynaud (1978) who gives the range as Ryazanian - Lower Valanginian. In the present study it was found in the Lower Valanginian beds D4 and D3 (Paratollia and Polyptychites Zones) and in the Lower Hauterivian beds C9 and C8 (regale Zone) at Speeton.

\section{Cymososphaeridium validum (79)}

This species has previously been recorded only from the Hauterivian of the North Sea and Denmark (Davey 1982a). In the present study it has been seen in the Lower Hauterivian bed D1 (noricum/amblygonium Zone) at Speeton.

Spiniferites ramosus subsp. primaevus (80)

This subspecies was recorded by Duxbury (1977) from the Lower Valanginian, and in the present study also from the lowermost Hauterivian (amblygonium Zone), at Speeton. It was also recorded by Davey (1982a) in beds assigned to the Hauterivian in the Haldager No. 1 borehole in Denmark, and by Below (1982d) in the Upper Aptian of Northwestern Germany where its presence just above a considerable unconformity suggests that it may be reworked.

\section{Kleithriasphaeridium sp. 1 (81)}

This form is recorded in the present study in the Lower Hauterivian beds D2D and D1 (amblygonium - ?noricum Zones) at Speeton.

\section{Muderongia extensiva (82)}

As mentioned by Duxbury (1977), the figured specimens named Muderongia tetracantha in Alberti (1961) should be referred to $M$. extensiva. The age was given as 'Valendis' and 'Unterhauteriv' and the samples were from Poland and Germany.

The range is further based on Duxbury (1977) and Davey (1982a).

\section{Phoberocysta tabulata (84)}

While there is little doubt as to the earliest record of this species (see remarks to $P$. neocomica) the last occurrence is less well documented. It is recorded in the present study as high as the Lower Hauterivian beds D2D and D1 (amblygonium - ?noricum Zones) at Speeton.

\section{Isthmocystis distincta (86)}

This species was first recorded by Duxbury (1979) from the Polyptychites Zone at Speeton. It has subsequently been found in the interval assigned as Early Portlandian - Hauterivian in the Haldager No. 1 borehole, Denmark (Davey 1982a), in the kochi Zone of the Danish North Sea E 1 well (Birkelund et al. 1983), and in beds D7G, D4 and D2D (?stenomphalus, Paratollia and amblygonium Zones) at Speeton (this study).

\section{Muderongia sp. 1 (88)}

This form is recorded by Gocht (1959) in samples from, and just above, the Lower Valanginian PolyptychitenSchicht and by Alberti (1961) from marine incursions in Eastern German Wealden sediments (Upper Ryazanian or Lower Valanginian).

Surculosphaeridium sp. III of Davey (1982a) (89)

The present study supports the observations of Davey (1982a) that this species is restricted to the Lower Valanginian at Speeton.

\section{Tubotuberella apatela (90)}

This species is found in the Polyptychites Zone at Speeton (bed D3) in the present study. The only Hauterivian record is in the Haldager borehole (Davey 1982a).

\section{Lagenorhytis delicatula (91)}

The highest occurrence of Lagenorhytis delicatula in the Speeton section is in the Paratollia Zone (Duxbury 1977 and this study). In the Haldager No. 1 borehole, however, it is recorded as high as the lowermost sample assigned to the Hauterivian.

The lowermost occurrence is in bed D7G (?stenomphalus Zone at Speeton (this study).

\section{Pseudoceratium sp. 1 (93)}

This early variety of Pseudoceratium pelliferum includes the specimens from the interval assigned as Lower Valanginian - Upper Ryazanian in the Danish Haldager borehole, figured in Davey (1979c: pl. 4, fig. 1 and 1982a: pl. 10, fig. 16).

\section{Muderongia simplex subsp. microperforata (94)}

According to Davey (1982a: 30) this subspecies occurs in the Upper Ryazanian to Lower Valanginian of the North Sea and in the Haldager No. 1 borehole, although in his range chart Davey (1982a) also shows the subspecies in one of his samples dated as Hauterivian in the Haldager borehole.

M. simplex subsp. microperforata was also recorded 
by Piasecki (1984) in sediments of probably Late Ryazanian age from Bornholm, Denmark.

\section{Chytroeisphaeridium cerastes (95)}

C. cerastes was originally described from the Lower Oxfordian (Davey 1979d). It is recorded in the present study in bed D5 (Albidum/Paratollia Zone) at Speeton.

\section{Occisucysta evittii (96)}

The forms described by Davey (1979c, 1982a) as Occisucysta sp. A and Occisucysta cf. evittii are here regarded as falling within the morphological range of $O$. evittii.

\section{Aldorfia spongiosa (98)}

A single Lower Hauterivian record is from Sklinnabanken, Norway (Aarhus et al. 1986). The highest record in the North Sea Basin is in the lowermost Valanginian (Paratollia Zone) bed D4 at Speeton, Eastern England (this study). Aldorfia spongiosa is recorded by Davey (1982a) from the Middle Volgian of Lincolnshire and at the Jurassic - Cretaceous transition in the Haldager No. 1 borehole.

\section{Gochteodinia villosa subsp. villosa (101)}

The Valanginian record of $G$. villosa (Raynaud 1978) is here assumed to be represented by $G$. villosa subsp. multifurcata. (The subspecies of $G$. villosa were first described after Raynaud presented his range chart).

Batioladinium cf. varigranosum sensu Davey (1982a) (104)

This form is recorded in the present study from bed D5 (Albidum or Paratollia Zone) at Speeton.

\section{Kleithriasphaeridium porosispinum (105)}

A single Lower Valanginian occurrence is from Sklinnabanken, Norway (Aarhus et al. 1986). Apart from this, $K$. porosispinum is not known with certainty to occur in deposits younger than the Upper Ryazanian stenomphalus Zone (Davey 1982a).

\section{Cannosphaeropsis thula (107)}

The possible record in the stenomphalus Zone is based
Ctenidodinium panneum (115)

A single Ryazanian occurrence is from Sklinnabankan, Norway (Aarhus et al. 1986).

on the occurrence of this species in bed D8 at Speeton (Duxbury 1977, as Adnatosphaeridium apiculatum). However, the exact age of bed D8 which occurs just above a major unconformity, is uncertain (cf. Casey 1973).

Dichadogonyaulax culmula (108)

According to Riding (1984) the highest record of this species is in the icenii Zone. In the present study it was recorded in bed D7G (?stenomphalus Zone) at Speeton.

Batioladinium sp. 1 of Davey (1982a) (109)

In Davey (1982a) two specimens (pl. 5, figs. 12 and 13) are illustrated from the Lower Valanginian but he (p. 22) gives the range as uppermost Volgian - Lower Ryazanian.

\section{Batioladinium pomum (110)}

This species is recorded in the lamplughi Zone in Eastern England (Davey 1982a), the kochi Zone in the Danish North Sea E 1 well (Birkelund et al. 1983), in bed D7G (?stenomphalus Zone) at Speeton (this study), and up to near the top of the Ryazanian in Denmark (Davey 1982a, Piasecki 1984).

Egmontodinium expiratum (111)

According to Riding (1984) the first occurrence of $E$. expiratum is in the kerberus Zone. Davey (1982a) regarded its presence in the intervals assigned as Upper Ryazanian and Valanginian in the Danish Haldager No. 1 borehole as possibly being due to reworking.

Egmontodinium polyplacophorum (114)

A single Ryazanian record is from Sklinnabanken, Norway (Aarhus et al. 1986). 


\section{Dinoflagellate analysis in the Danish Central Trough and ammonites in the Adda-2 well}

This section presents the age determinations of selected wells in the Danish Central Trough, and the evidence on which the ages are based.

The ages are based on the Northwest European ranges of species as presented in the previous section.

The results are generally presented with the uppermost sample of a particular well being described first, and the lowermost sample last. This is convenient because the ages are based on first downhole occurrences (last stratigraphical occurrences) of species in ditch cutting samples.

The geographical and structural positions of the wells are shown in fig. 1.

\section{The Adda-1 well}

Summary of age determinations

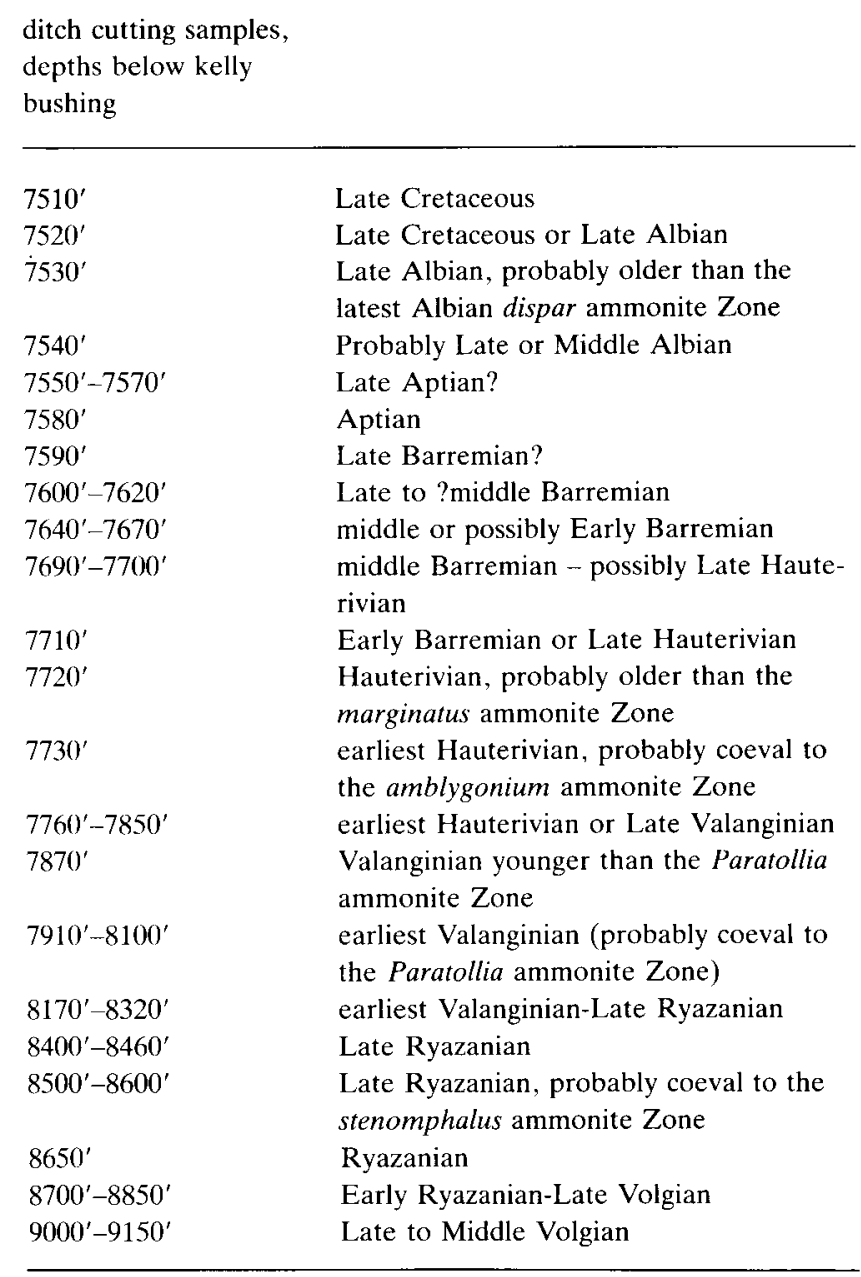

Side-wall cores

\begin{tabular}{ll}
\hline $9170^{\prime}$ & Middle Volgian \\
$9378^{\prime}-9542^{\prime}$ & Early to early Middle Volgian
\end{tabular}

Discussion of ages

Most of the dinoflagellates recorded from the Adda-1 well are shown in the range charts based on cutting samples (fig. 5) and side-wall cores (fig. 6). The ages are interpreted as follows:

$7510^{\prime}$. The Late Cretaceous age is based on a dinoflagellate assemblage composed of a few Upper Cretaceous and several Tertiary species. The latter group is evidently present as a result of drilling-mud contamination, and the small in situ assemblage indicates a low dinoflagellate content at this depth. According to Foucher (1979) the presence of Cyclonephelium membraniphorum points to a pre-Campanian age.

$7520^{\prime}$. The sample only contains contaminated Tertiary species. The age is based on age-indications above and below.

$7530^{\prime}$. The sample is rich in dinoflagellate species restricted to the Albian-Cenomanian. The highest occurrences of Ascodinium scabrosum, Litosphaeridium conispinum and Apteodinium grande are considered as confident top-Albian markers, and Litosphaeridium arundum points to an age older than the latest Albian dispar ammonite zone.

$7540^{\prime}$. The probably Middle or Late Albian age is based on the downhole appearance of Carpodinium granulatum which indicates an age no younger than the Late Albian inflatum Zone. Dinopterygium cladoides (several specimens) and Psaligonyaulax deflandrei (one questionable specimen) have not been reported below the Middle Albian, and Isabelidinium gallium, which occurs here (and again at $7570^{\prime}$ ), is only known from the latest Albian.

$7550^{\prime}-7570^{\prime}$. No downhole appearances of age-diagnostic species occur in this interval. However, the Albian assemblage present in the samples above is essentially absent which may suggest a pre-Albian age.

At $7580^{\prime}$ a considerable number of species make their first downhole appearance. Several of them have previously been reported to occur in the Albian of NW Europe. However, Cerbia tabulata and a questionable Achomosphaera neptunii point to an age no younger than the Late Aptian. Aptea securigera and Dingodi- 


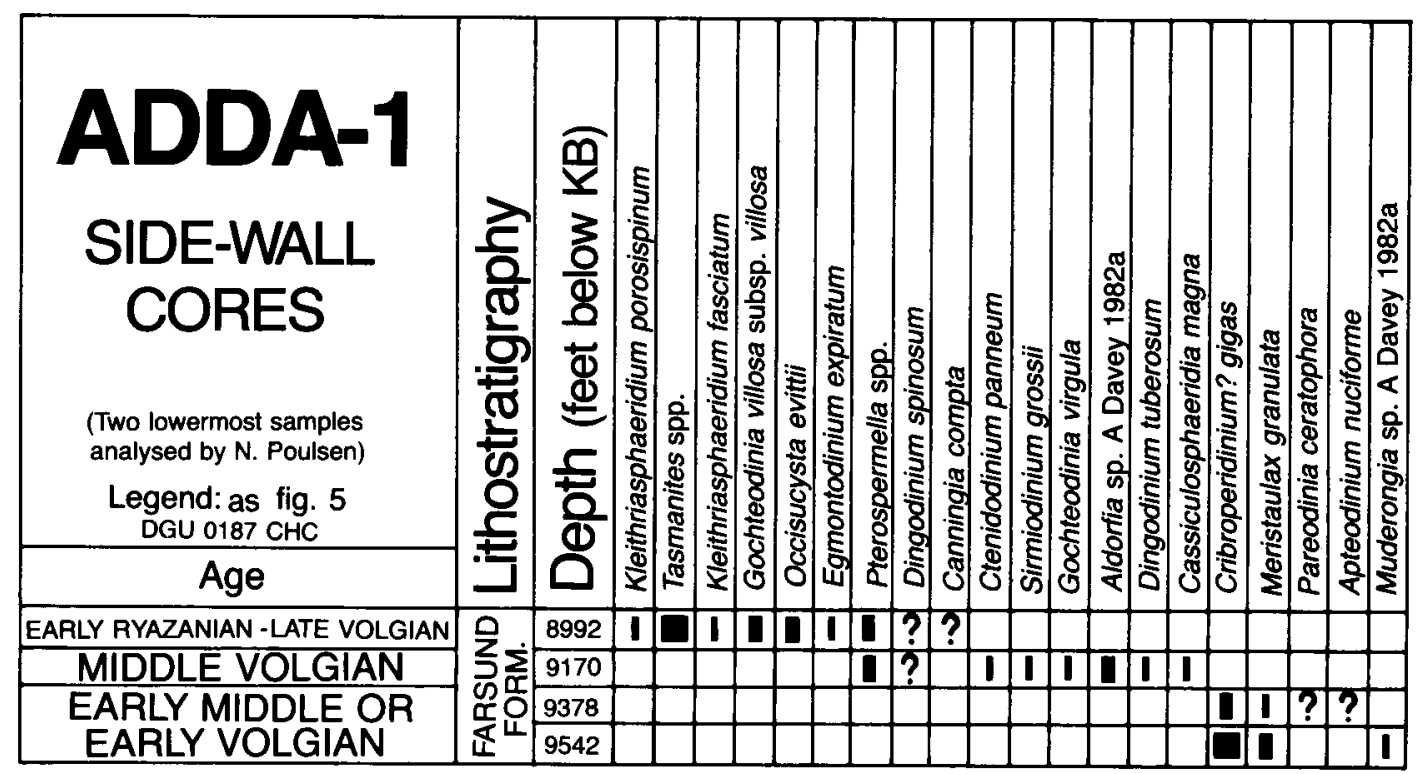

Fig. 6. Dinoflagellates in side-wall cores of the Adda-1 well.

nium cerviculum ranges into the earliest Albian but are more characteristic of the Aptian.

$7590^{\prime}-7620^{\prime}$. Several species make their first downhole appearance in the sample at $7590^{\prime}$. Among these, Phoberocysta neocomica, Chlamydophorella trabeculosa and Pseudoceratium pelliferum (a questionable specimen) are prominent markers of Early Aptian or older strata. Diphasiosphaera stolidota (doubtfully identified) suggests an earliest Aptian or older age, and Cribroperidinium boreas (also doubtfully identified) marks the top of the Barremian. In the next sample (at $7600^{\prime}$ ) Batioladinium longicornutum, which is a reliable top Barremian marker, makes its first downhole appearance. The Barremian age is supported by a questionable Trichodinium speetonensis. The first downhole occurrence of Subtilisphaera perlucida also occurs here. The abundance of this species down to and including the sample at $7660^{\prime}$ is possibly of some significance. $S$. perlucida ranges into the Albian, but is very abundant in the middle Barremian sample from Speeton inspected in the present study. At 7610' the first undoubted Diphasiosphaera stolidota and a questionable Avellodinium falsificum supports the Barremian age indicated above. A further Barremian indicator, Cassiculosphaeridia magna, appears at $7620^{\prime}$, and a doubtful Isthmocystis distincta in the same sample is presumably reworked from the Hauterivian or older strata, while a Stephodinium coronatum is considered to be caved from the latest Aptian or younger levels.

$7640^{\prime}-7670^{\prime}$. The middle or possibly Early Barremian age is based on the first downhole occurrence of Kleithriasphaeridium corrugatum at $7640^{\prime}$ and its presence in several of the subsequent samples. The stratigraphically highest record of this species is in the lowermost part of the middle Barremian at Speeton (Duxbury 1980), although it is possibly more typical of the Lower Barremian and older deposits. However, a number of species characteristic of the middle to Late
Barremian are also met with here for the first time: Cribroperidinium cornutum (questionable at $7640^{\prime}$ but certain below), Ellipsodinium reticulatum at $7660^{\prime}$ and $7670^{\prime}$, and Rhynchodiniopsis aptiana at 7650'.

$7690^{\prime}-7700^{\prime}$. Two atypical specimens at $7690^{\prime}$ have been doubtfully identified as Gonyaulacysta kostromiensis. This is a weak indication that layers of earliest Barremian - Hauterivian age may be penetrated here, although no other features of the assemblage indicate a pre-Barremian age. Sirmiodiniopsis frisia is considered reworked at $7690^{\prime}$.

$7710^{\prime}$. The Early Barremian or Late Hauterivian age is based on the occurrence of Muderongia tetracantha, although this species has also been recorded in the Aptian by Below (1982d) (see previous section).

A marked change in the assemblage takes place at $7720^{\prime}$. Pseudoceratium pelliferum and Hystrichodinium voigtii, which are infrequent above, are abundant in this and the underlying samples, while the Cribroperidinium orthoceras-edwardsii group, which is frequent above, now decreases rapidly. Several species make their first downhole appearance. The Hauterivian age is based on the highest occurrence of Phoberocysta tabulata which becomes frequent in the subsequent samples, on Hystrichosphaeridium scoriaceum and on common to abundant Muderongia simplex in all samples from $7720^{\prime}$ to $8320^{\prime}$. The Hauterivian age may be further supported by the appearance of Chlamydophorella membranoidea which becomes frequent in the subsequent samples. It should be noted, however, that C. membranoidea is also recorded in the Upper Aptian of Northwestern Germany (Davey 1982b).

$7730^{\prime}$. A large number of species make their first appearance at this depth. The earliest Hauterivian age is based on the first downhole occurrence of Isthmocys-

Fig. 5. Dinoflagellates in ditch cuttings of the Adda-1 well. 


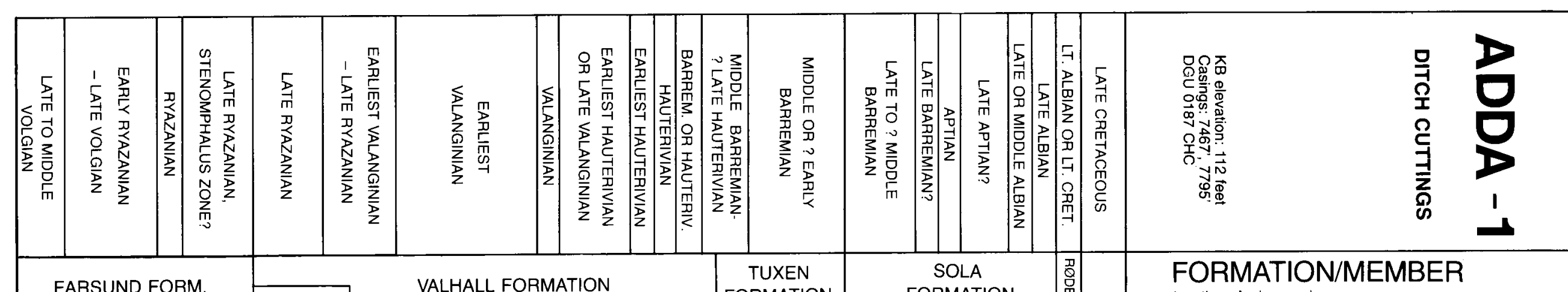

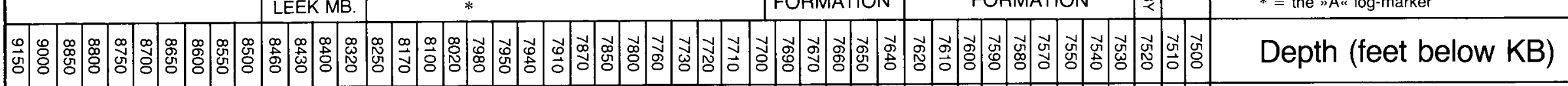

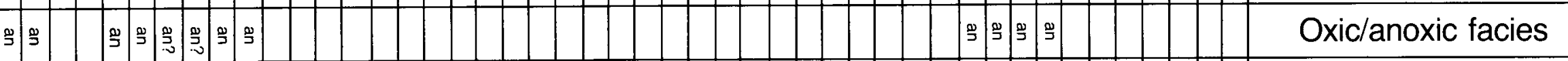

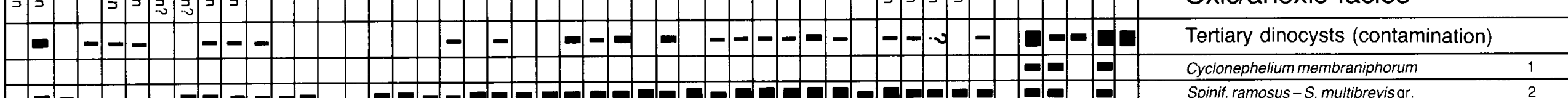

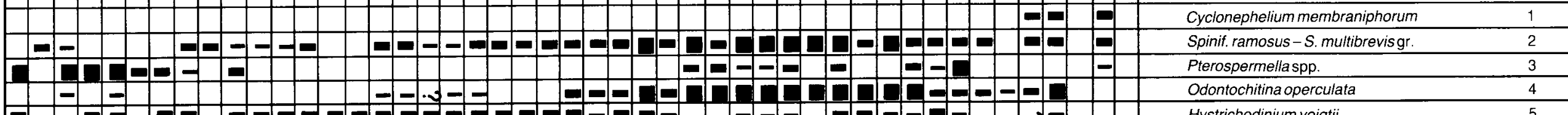

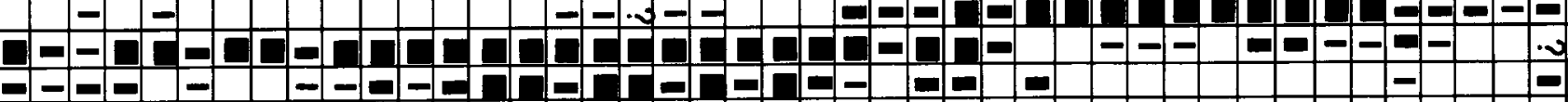

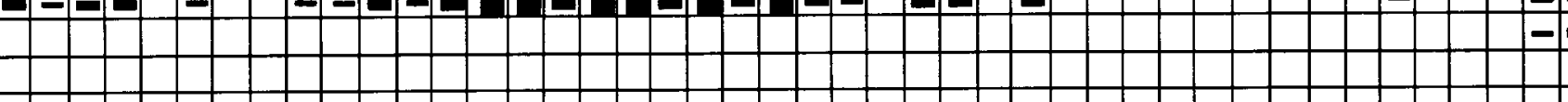

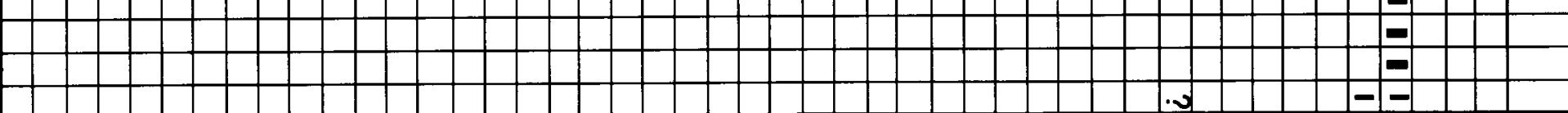

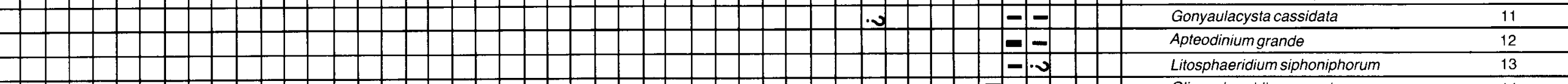

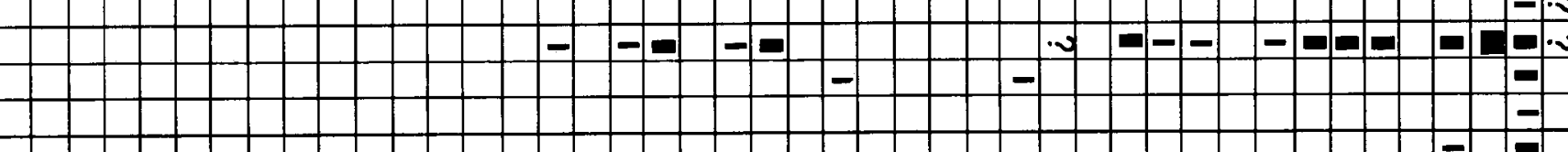

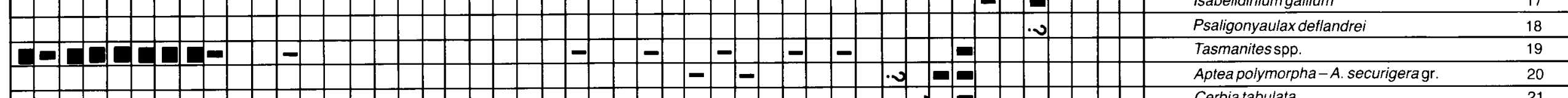

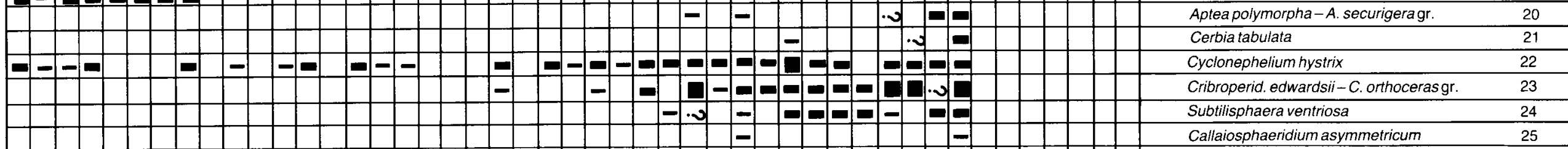

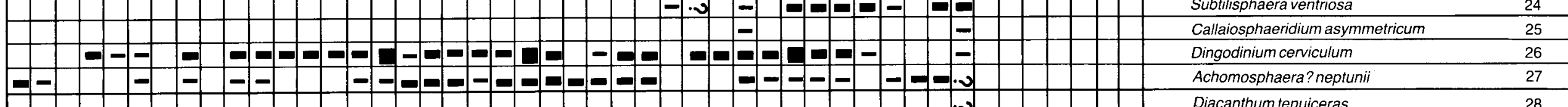

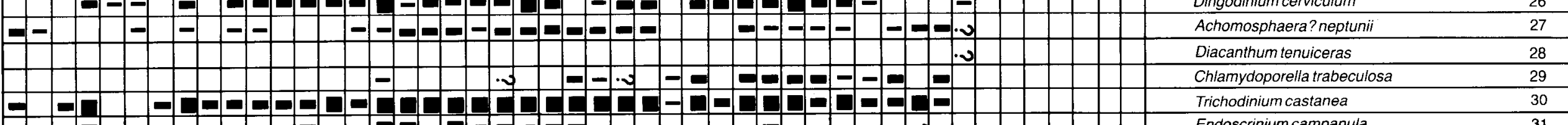
-

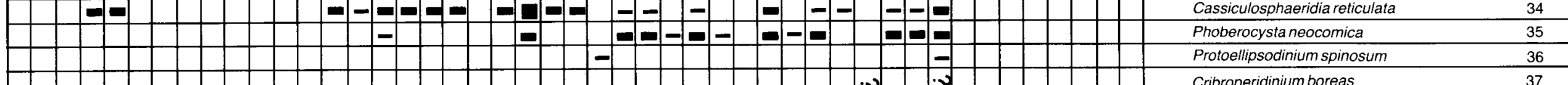
C...

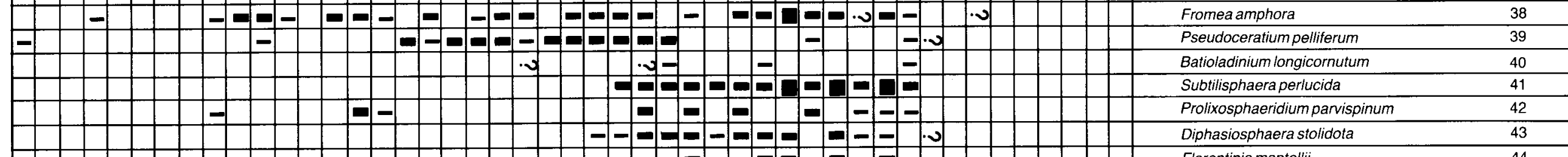

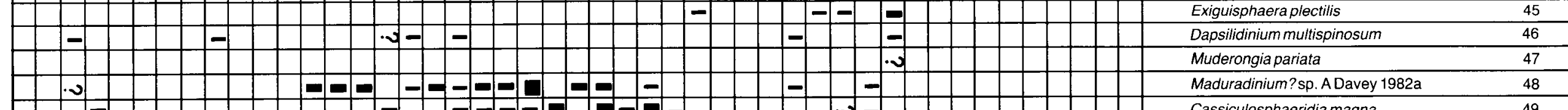

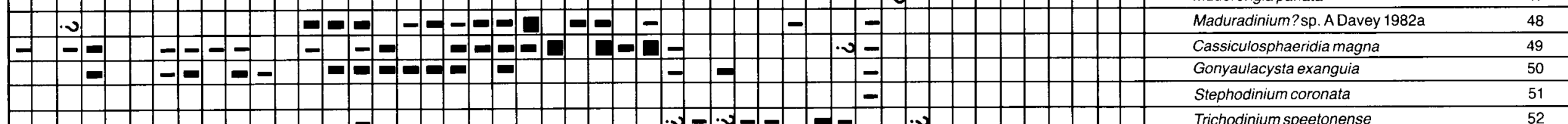

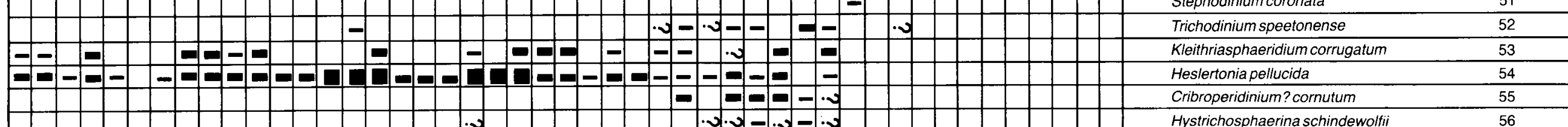

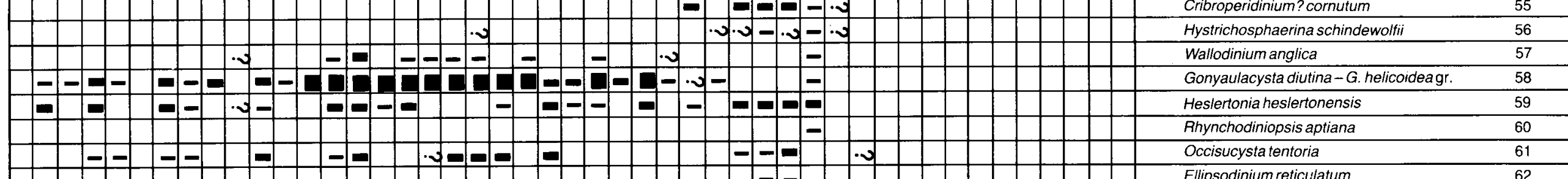

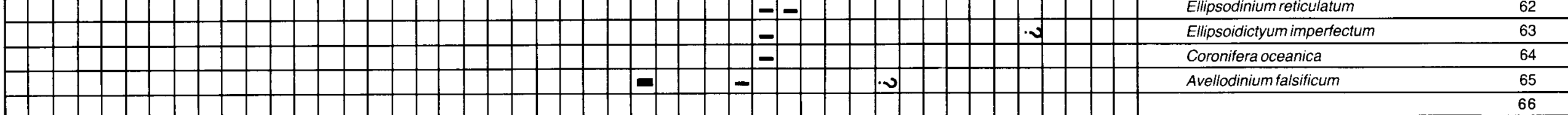

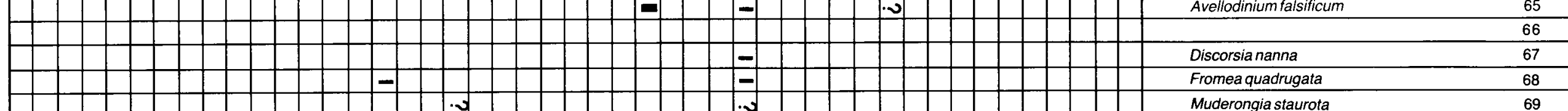

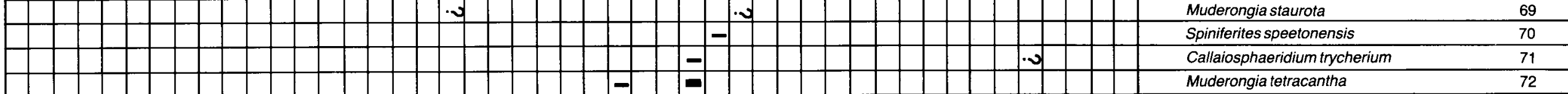

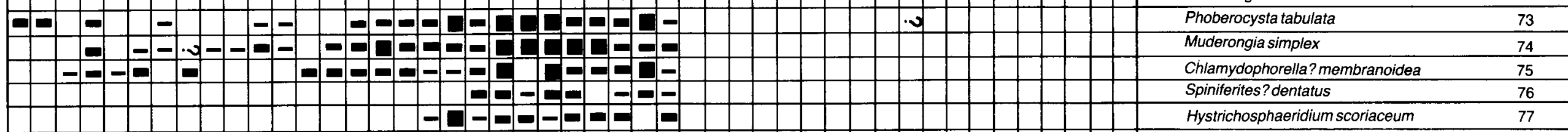
\begin{tabular}{|c|c|c|c|}
\hline & & &
\end{tabular}

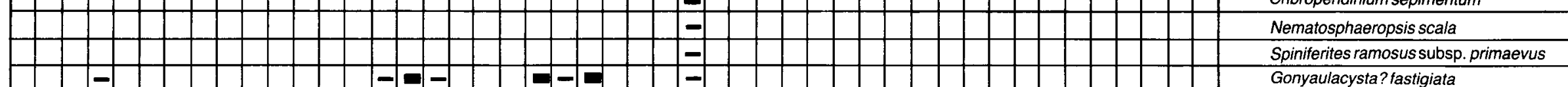

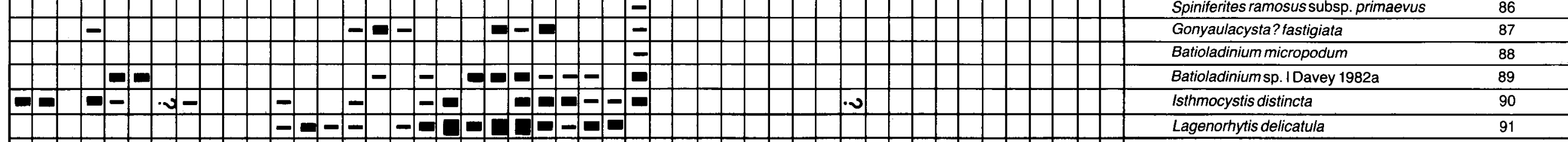

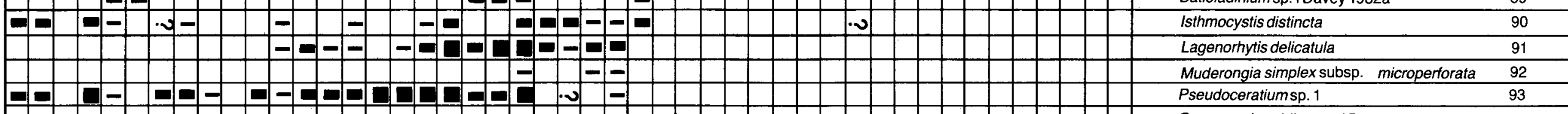

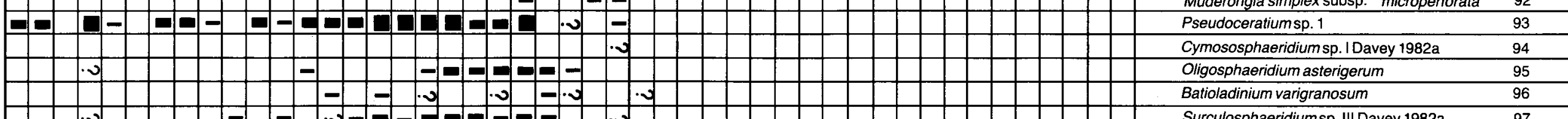

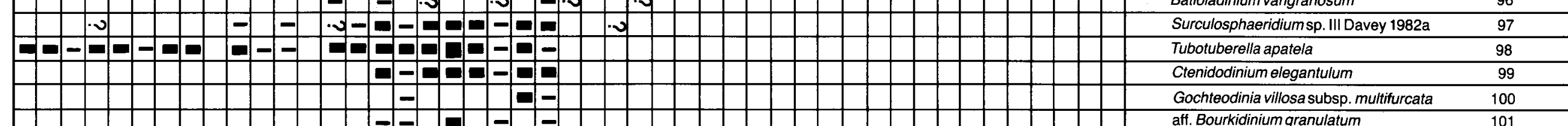

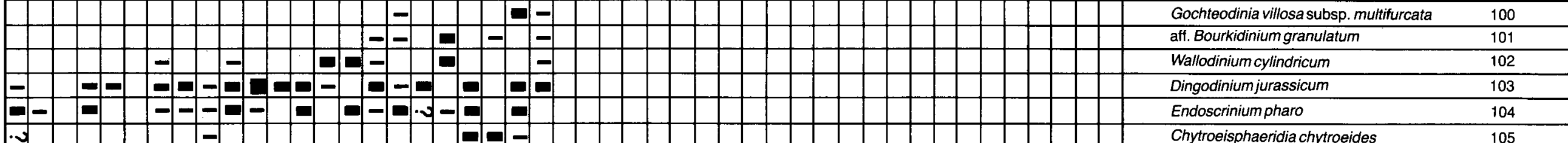

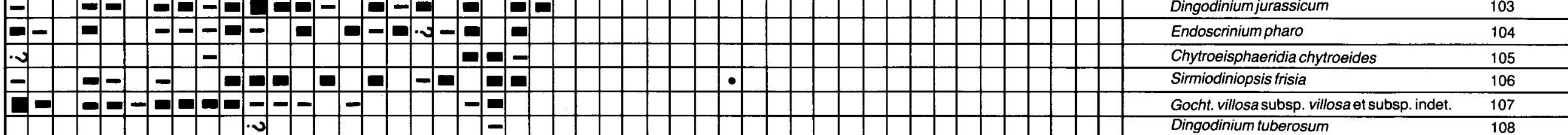

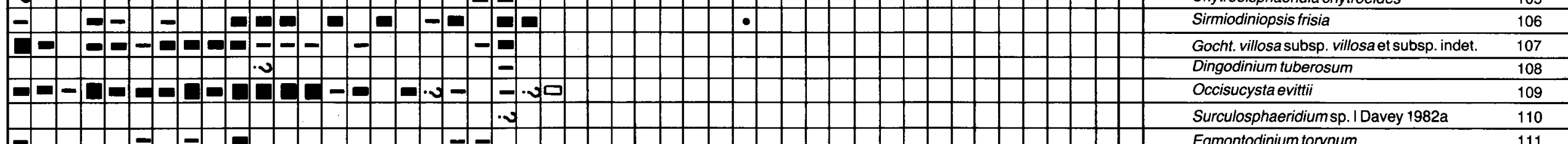

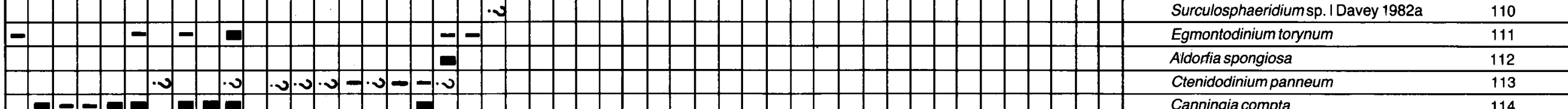

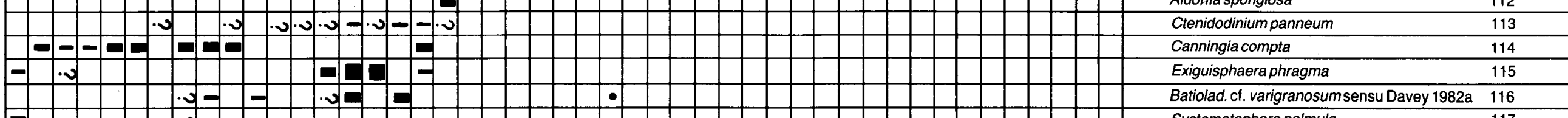

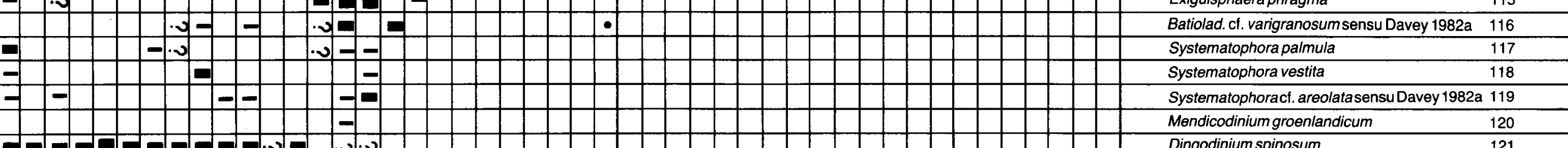

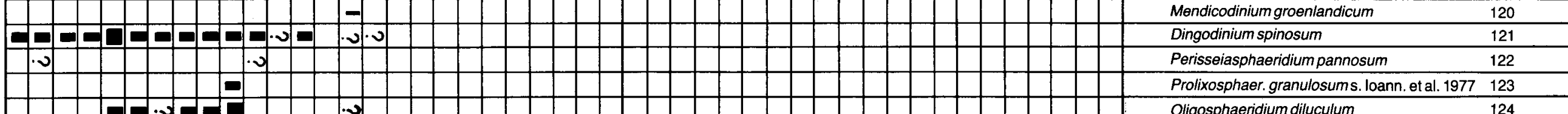

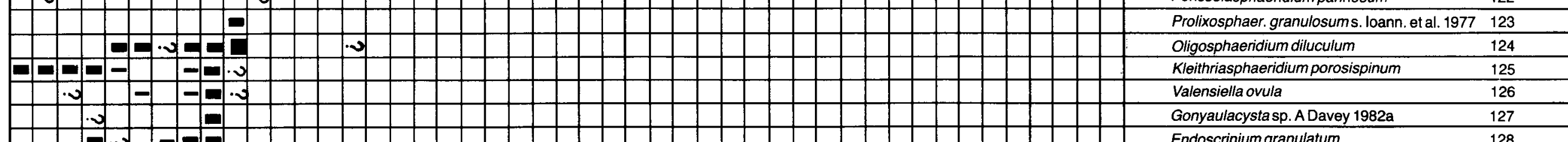

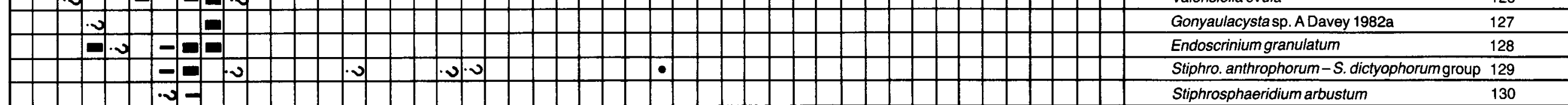

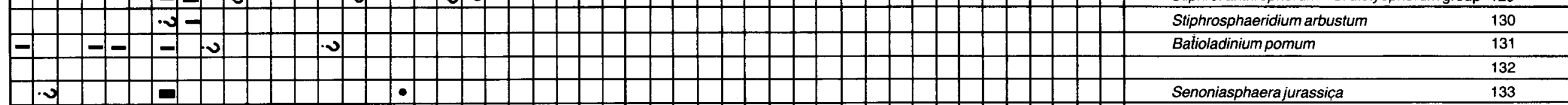

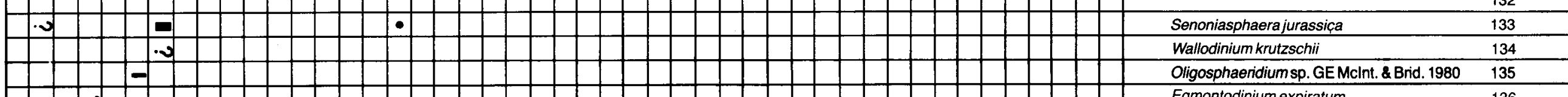

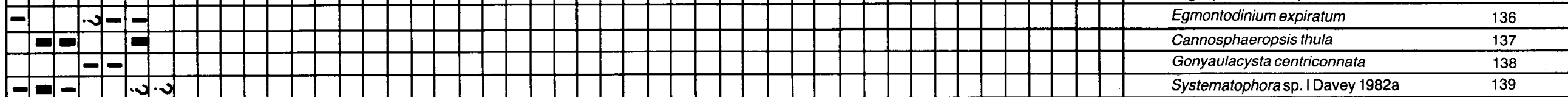

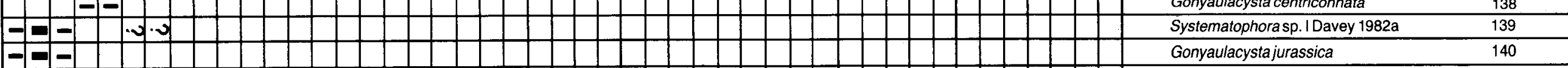

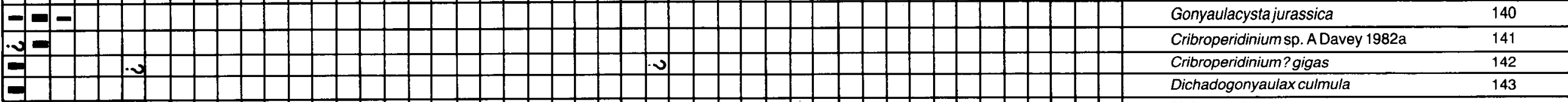

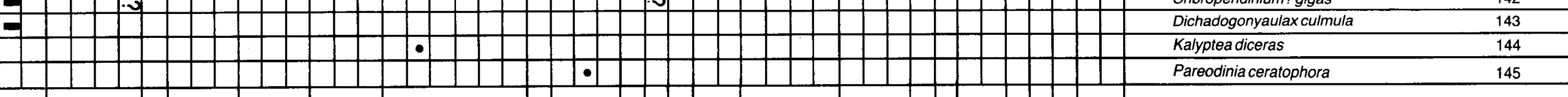

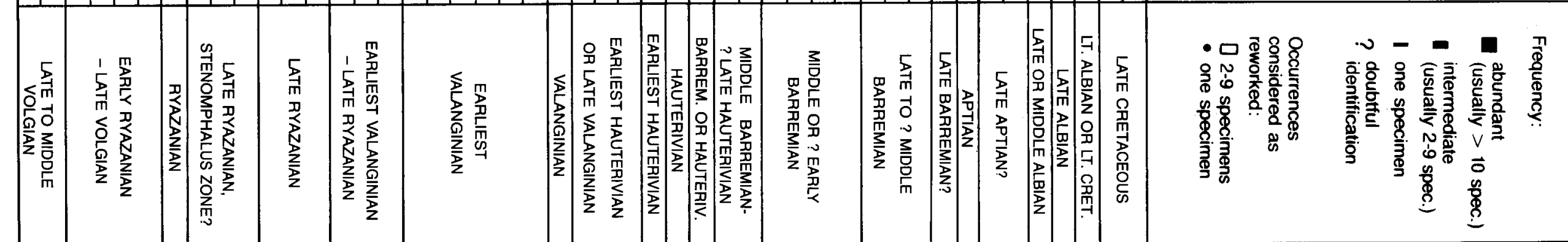


tis distincta which is also present in the subsequent samples, and on the presence of Spiniferites ramosus subsp. primaevus. A questionable Batioladinium varigranosum supports an earliest Hauterivian age, since it is recorded as high as the amblygonium Zone by Duxbury (1977).

The first appearance of undoubted Gonyaulacysta kostromiensis and Nematosphaeropsis scala also take place at $7730^{\prime}$. These highest occurrences are anomalously low; however, affinity to the earliest Hauterivian appears to be stronger than to younger parts of the Hauterivian.

Batioladinium sp. I of Davey (1982a) is probably not reworked since it is present in most samples from $7730^{\prime}$ to $8170^{\prime}$.

$7760^{\prime}-7850^{\prime}$. The first downhole appearance at $7760^{\prime}$ and consistent presence in the subsequent samples of Lagenorhytis delicatula is considered to be a strong indication that earliest Hauterivian or older strata are present. Very little is known about dinoflagellate distribution during the Late Valanginian, as has been discussed in the previous section. Muderongia simplex subsp. microperforata and a questionable Surculosphaeridium sp. III of Davey (1982a), which are also present at $7760^{\prime}$, are previously found only in the Lower Valanginian, but more distinct Lower Valanginian markers do not appear until $7870^{\prime}$, and the presence of the two species may equally indicate younger parts of the Valanginian. Single specimens of Batioladinium cf. varigranosum sensu Davey (1982a) at $7760^{\prime}$ and of Pareodinia ceratophora at $7800^{\prime}$ are considered as reworked. The first downhole occurrence of Oligosphaeridium asterigerum at $7850^{\prime}$ is lower than expected.

$7870^{\prime}$. The highest occurrence of a number of prominent markers takes place here. Of these, Gochteodinia villosa subsp. multifurcata and Batioladinium varigranosum are known to range as high as the earliest Hauterivian. The Valanginian age is based on the downhole appearance of Tubotuberella apatela and undoubted Surculosphaeridium sp. III of Davey (1982a), and is supported by the presence of Ctenidodinium elegantulum and Dingodinium jurassicum. The latter two species have well defined highest occurrences in the I-1 well in the interval assigned as Valanginian above earliest Valanginian.

Earliest Valanginian markers only appear in the underlying samples and an age younger than the earliest Valanginian can therefore be assigned. One species marking the earliest Valanginian, namely Occisucysta evittii, does occur here. It is not consistently present until $8100^{\prime}$ (or even $8250^{\prime}$ ) and is therefore considered to be reworked.

$7910^{\prime}-8100^{\prime}$. The earliest Valanginian age assigned to this considerable interval (comparable to the thickness of the earliest Valanginian in the I-1 well) is based on the first downhole appearances of several species which have their highest known on-shore occurrence in the Paratollia Zone at Speeton. Furthermore, Ryazanian markers do not appear until 8170' and beneath. The age assignment therefore appears to be well established.

The species on which the age is based and some of the other species occurring in this interval are now considered: Endoscrinium pharo, Sirmiodiniopsis frisia and Chytroeisphaeridia chytroeides appear at $7910^{\prime}$. E. pharo, which occurs regularly in the subsequent samples, is a distinct marker of the Paratollia Zone and older strata at Speeton. S. frisia, reported by Raynaud (1978) to have a highest occurrence at the MiddleUpper Valanginian boundary in the North Sea area appears downhole simultaneously with Endoscrinium pharo in the I-1 well. Chytroeisphaeridia chytroeides is closely related to $C$. cerastes, which is recorded in the earliest Valanginian at Speeton.

Occisucysta evittii is sporadic from $7940^{\prime}$ to $8100^{\prime}$ and may possibly be reworked since according to Davey $(1979 \mathrm{c})$ it occurs consistently in the earliest Valanginian.

Egmontodinium torynum appears at 7950', and $\mathrm{Al}$ dorfia spongiosa at $7980^{\prime}$. Ctenidodinium panneum, present at $8020^{\prime}$ and $8100^{\prime}$, is usually considered to be restricted to the Kimmeridgian-Middle Volgian where it may be frequent, and is therefore possibly reworked. It should be noted, however, that questionable $C$. panneum also occur in the Valanginian of the I-1 well. According to Davey (1982a) the range of Canningia compta, appearing at $8020^{\prime}$, is Middle Volgian - earliest Valanginian. A single specimen of Kalyptea diceras in this sample is considered reworked from the MiddleLate Volgian.

Batioladinium cf. varigranosum sensu Davey (1982a) appears at $8100^{\prime}$. A single specimen in this sample of Senoniasphaera jurassica is considered as reworked, since according to Raynaud (1978) and Davey (1979c) it is restricted to the Volgian and Kimmeridgian.

$8170^{\prime}-8320^{\prime}$. The earliest Valanginian or Late Ryazanian age is based on the questionable presence of the Ryazanian marker Dingodinium spinosum at $8170^{\prime}$ and $8250^{\prime}$. Safely identified specimens are not encountered until $8400^{\prime}$.

Systematophora palmula, also appearing at $8170^{\prime}$, appears in the I-1 well simultaneously with in situ $D$. spinosum.

$8400^{\prime}-8460^{\prime}$. The Late Ryazanian age is based on the highest undoubted occurrence of Dingodinium spinosum at $8400^{\prime}$ and its regular occurrence in the subsequent samples.

$8500^{\prime}-8600^{\prime}$. Late Ryazanian, probably coeval to the stenomphalus Zone. The age is based on the appearance and abundance at $8500^{\prime}$ of Oligosphaeridium diluculum, which is only known with certainty from the stenomphalus Zone in Eastern England (Davey 1982a). It is supported by the regular occurrence of Canningia 
compta at $8500^{\prime}$ and below, and by the presence of Kleithriasphaeridium porosispinum and Stiphrosphaeridium arbustum. S. arbustum has previously been recorded only from the icenii - stenomphalus Zones in Eastern England.

At $8500^{\prime}$ a marked change in facies indicates penetration of the Farsund Formation. A similar change in facies is observed between $10970^{\prime}$ and $11000^{\prime}$ in the I-1 well and according to Costa (1981) and Davey (1982a) also when penetrating the Kimmeridge Clay facies (including the Farsund Formation) throughout the North Sea Basin. The change is marked by a sharp increase in the amount of sapropelic organic matter and by the regular occurrence of the facies-dependant Pterospermella spp. which are not recorded in the immediately overlying deposits. Pterospermella becomes abundant from $8750^{\prime}$ and to the base of the studied interval. Furthermore, a sharp downwards increase and subsequent abundance of Tasmanites spp. takes place between $8550^{\prime}$ and $8600^{\prime}$.

$8650^{\prime}$. This age of this interval is interpreted as Ryazanian although several specimens of Senoniasphaera jurassica occur at $8650^{\prime}$. According to Raynaud (1978) and Davey (1979c), S. jurassica indicates a Middle Volgian or older age. This species is absent, however, in the underlying samples, and reliable Lower Ryazanian markers do not appear until $8700^{\prime}$. Therefore $S$. jurassica may either be reworked here, or it may have been sporadically present during the Ryazanian. Batioladinium pomum, which also occurs at $8650^{\prime}$, is seen in bed D7G (?stenomphalus Zone) at Speeton in this study. Stiphrosphaeridium dictyophorum in the same sample is very common in the Lower Ryazanian in Eastern England.

$8700^{\prime}-8850^{\prime}$. The first downhole occurrence at $8700^{\prime}$ of Cannosphaeropsis thula and Egmontodinium expiratum clearly points to an Early Ryazanian-Late Volgian age. C. thula is previously recorded as common from the upper part of the Middle Volgian to the Lower Ryazanian in Eastern England while E. expiratum in Eastern England ranges from Middle Volgian to lowermost Ryazanian (runctoni Zone) (Davey 1982a). According to Raynaud (1978) Cribroperidinium? gigas (a questionable specimen) is restricted to the Volgian in the North Sea area. Systematophora sp. I of Davey (1982a), which is present at $8850^{\prime}$ and in the subsequent samples, is recorded by Davey (1982a) from the Kimmeridgian-Early Ryazanian in Eastern England and is especially common in the Kimmeridgian-Portlandian.

The presence of Gonyaulacysta jurassica at $8850^{\prime}$ and in the subsequent samples is noteworthy. According to Raynaud (1978) and Riding (1984) the highest in situ occurrence of this species is in the lower part of Middle Volgian. As it is a frequent species in the Upper Jurassic, the presence both here and in the interval assigned the same age in the I-1 well may possibly be due to reworking.
Side-wall core at $8992^{\prime}$ (fig. 6). The presence of Egmontodinium expiratum and of frequent Tasmanites points to an Early Ryazanian or Late Volgian age (Davey 1982a) as was indicated by the cutting samples above. Kleithriasphaeridium fasciatum is not previously recorded below the uppermost Ryazanian and the presence of this species is possibly due to drilling-mud contamination.

$9000^{\prime}-9150^{\prime}$. The Late to Middle Volgian age is based on the appearance of Cribroperidinium sp. A of Davey (1982a) at 9000' and of undoubted specimens of Cribroperidinium? gigas at $9150^{\prime}$. Cribroperidinium sp. A is recorded by Davey (1982a) from the Middle and Upper Volgian in England, and C.? gigas is reported to occur in the Lower and Middle Volgian in the North Sea area (Raynaud 1978).

Side-wall core at $9170^{\prime}$ (fig. 6). The age is Middle Volgian, based on the presence of Ctenidodinium panneum, Aldorfia sp. A of Davey (1982a) and Gochteodinia virgula. G. virgula is previously known from both the Middle and Upper Volgian while, according to Davey (1982a), Aldorfia sp. A is relatively common in the upper Middle Volgian kerberus and anguiformis Zones in Lincolnshire, England. The last occurrence of C. panneum is in the anguiformis Zone.

Side-wall cores at $9378^{\prime}$ and $9542^{\prime}$ (fig. 6). The analysis and age interpretation of these two samples has been carried out by Niels Poulsen, Geological Survey of Denmark. The age is Early or early Middle Volgian based on the occurrence of Cribroperidinium? gigas and Muderongia sp. A of Davey (1982a), both with a known range within the Lower and Middle Volgian, and Meristaulax granulata, which is not recorded above the lower part of Middle Volgian.

\section{The I-1 well}

Summary of age determinations

\section{ditch cutting samples,}

depths below kelly

bushing

$\begin{array}{ll}9340^{\prime} & \text { Late Cretaceous } \\ 9360^{\prime} & \text { Albian } \\ 9370^{\prime} & \text { Albian, probably earliest Albian } \\ 9380^{\prime}-9420^{\prime} & \text { earliest Albian or Aptian } \\ 9440^{\prime} & \text { Aptian } \\ 9460^{\prime} & \text { earliest Aptian } \\ 9480^{\prime} & \text { Late Barremian } \\ 9490^{\prime}-9520^{\prime} & \text { middle Barremian } \\ 9540^{\prime}-9660^{\prime} & \text { middle or Early Barremian } \\ 9760^{\prime}-9780^{\prime} & \text { Early Barremian or Late Hauterivian } \\ 9810^{\prime}-9850^{\prime} & \text { Late Hauterivian? } \\ 9870^{\prime}-9900^{\prime} & \text { Hauterivian (probably earliest Late } \\ & \text { Hauterivian or older) }\end{array}$

Fig. 7. Dinoflagellates in ditch cuttings of the I-1 well. 
$9960^{\prime}-10020^{\prime}$

$10090^{\prime}-10220^{\prime}$

$10290^{\prime}-10470^{\prime}$

$10530^{\prime}-10750^{\prime}$

$10770^{\prime}-10790^{\prime}$

$10810^{\prime}-10970^{\prime}$

$11000^{\prime}-11120^{\prime}$

$11150^{\prime}-11300^{\prime}$

core 5 ,

driller's depths

below kelly bushing

9495'-9524'

$9539^{\prime}$

middle Barremian - earliest Aptian

Near Early - middle Barremian boundary

\section{Discussion of ages}

Most of the dinoflagellates recorded from the I-1 well are shown in the range charts (figs. 7,8). The ages are interpreted as follows (unless specified otherwise samples are ditch cutting samples):

$9340^{\prime}$. The dinoflagellate assemblage in this sample is enriched with Tertiary species due to drilling mud contamination, and only includes few in situ species. Of these, Cyclonephelium membraniphorum indicates a pre-Campanian age (Foucher 1979). The Late Cretaceous age is based on the absence of Albian markers, which have highest occurrences in the underlying samples.

$9360^{\prime}$. The Albian age is based on the presence of Diacanthum tenuiceras. However, more distinct Albian markers are not encountered until the next sample.

$9370^{\prime}$. The age is probably earliest Albian since Dingodinium cerviculum is recorded in this sample. However, the sample also includes the first downhole occurrence of the Late Albian markers Carpodinium granulatum and questionable Ascodinium scabrosum, and of the Middle Albian marker Cauca parva. A more typical earliest Albian or Aptian assemblage does not appear until the next sample, and a condensed younger Albian sequence is probably present between $9370^{\prime}$ and $9360^{\prime}$.

$9380^{\prime}-9420^{\prime}$. The earliest Albian or Aptian age is based on the first downhole occurrence of the three earliest Albian markers Protoellipsodinium clavulum and Aptea polymorpha (at 9380') and Kleithriasphaeridium eoinodes (at 9420'). Aptea polymorpha becomes abundant at $9420^{\prime}$ and in the underlying samples. Leptodinium cancellatum, which is present at $9400^{\prime}$ and $9420^{\prime}$, was previously found near the Aptian/Albian boundary in Northwest Germany and in the northern North Sea (Davey 1982b). A single specimen of Chlamydophorella membranoidea at $9380^{\prime}$ may support an Aptian rather than earliest Albian age. Minor reworking of Valanginian or older sediments is indicated by a single specimen of Tubotuberella apatela. $9440^{\prime}$. The age assignment of this sample is problematical. A single specimen of Cassiculosphaeridia magna points to a Barremian age since this species has not previously been recorded above the Barremian. Furthermore, Spiniferites dentatus (a single specimen) has only been recorded once above the middle Barremian, namely in the Upper Aptian of Northwestern Germany (Below 1982d). Since earliest Aptian markers are not met with until the next sample, the age is assigned to the Aptian, and C. magna and $S$. dentatus are considered as probably reworked.

$9460^{\prime}$. The earliest Aptian age is based on the first downhole occurrence of Phoberocysta neocomica. This species occurs as high as the earliest Aptian forbesi ammonite zone on the Isle of Wight, southern England (Duxbury 1983), and the absence of this characteristic species above the forbesi Zone is well documented.

$9480^{\prime}$. The appearance of several specimens of Cassiculosphaeridia magna, and a questionable specimen of Avellodinium falsificum indicate penetration of Barremian strata. A single specimen of Apteodinium grande must result from caving since this species is restricted to the Middle-Late Albian.

$9490^{\prime}-9540^{\prime}$. A middle -Early Barremian assemblage is present in the sample at 9490'. This assemblage includes in particular Kleithriasphaeridium corrugatum, Cribroperidinium cornutum, Fromea quadrugata, Trichodinium speetonensis, Muderongia staurota, Hystrichosphaerina schindewolfii and Pseudoceratium pelliferum. Of these $P$. pelliferum and $H$. schindewolfii are known to range into the Early Aptian and earliest Albian respectively, but the others are absent above the Barremian. $K$. corrugatum has not been reported higher than the lower part of the middle Barremian, and it therefore seems that middle Barremian strata are penetrated at $9490^{\prime}$. Hystrichodinium ramoides at $9510^{\prime}$ is typical for the middle-Late Barremian.

$9540^{\prime}-9660^{\prime}$. The assemblage in the ditch cuttings at 9540' still has a middle Barremian aspect: Trabeculodinium quinquetrum which is relatively common, is restricted to the middle Barremian at Speeton (Duxbury 1980). A questionable Hystrichodinium furcatum probably points to the lower part of middle Barremian, or older strata. Despite this apparently clear middle Barremian age indication in the $9540^{\prime}$ - ditch cuttings, the age of the interval is given as middle or Early Barremian on the basis of the core sample at 9539' (see below).

The samples from $9580^{\prime}$ to $9660^{\prime}$ only include relatively few dinoflagellates, and species already recorded above are present. (A questionable Cerbia tabulata at $9580^{\prime}$ suggests that strata of middle Barremian age are possibly still present). A single Nannoceratopsis gracilis at $9600^{\prime}$ is reworked from Lower-Middle Jurassic strata. 


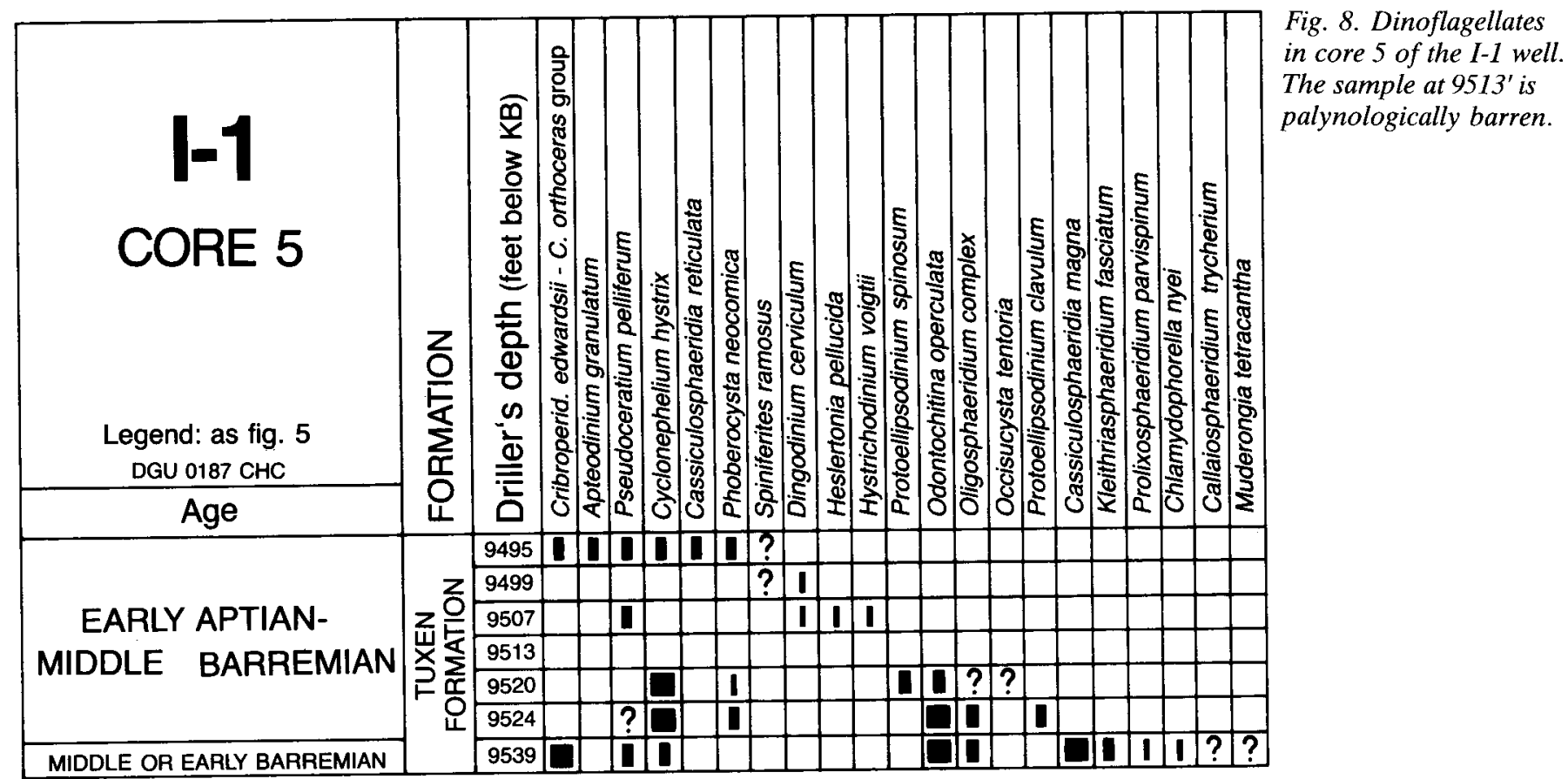

Core 5

This core falls entirely in the Tuxen Formation. The top of this formation is defined at $9507^{\prime}$ on wire-line logs (Jensen et al. 1986). According to the driller's depths used in the present study, core 5 covers the interval $9495^{\prime}$ to $9539^{\prime}$. Consequently the top of the Tuxen Formation as defined on wire-line logs should be corrected upwards at least 12 ' in order to agree with driller's depths.

The organic particles (including the dinoflagellates) are corroded in most of the core samples but a number of stratigraphically significant species have been identified (fig. 8).

Core samples at 9495'-9524' (driller's depths). The assemblage in these samples is characteristic of middle Barremian - Early Aptian. Abundant Odontochitina operculata in the lowermost two samples points to an age no older than Early Barremian, while Protoellipsodinium clavulum at $9524^{\prime}$ is not recorded below middle Barremian.

Core sample at 9539' (driller's depth). The presence of Kleithriasphaeridium fasciatum points to an age no younger than the earliest part of the middle Barremian. On the other hand the abundance of Odontochitina operculata indicates that the age cannot be much older than the boundary between Early and middle Barremian.

\section{Caving}

The core samples permit evaluation of the amount of specimens resulting from caving in cutting samples of the same interval and below. The presence of Aptea polymorpha in these cutting samples is clearly due to caving, as this species is absent in the core. A. polymorpha is restricted to the Aptian and basal Albian in on-shore sections, and the significant numbers of this species down to $10470^{\prime}$ shows that considerable caving of Aptian layers has taken place during drilling of this sequence. The important amount of Odontochitina operculata down to $10020^{\prime}$ may also be derived from this caving since its lowermost on-shore occurrence is in the Lower Barremian.

$9760^{\prime}-9780^{\prime}$ (ditch cuttings). The assemblage continues to be poor in this interval, and no age diagnostic species are present. The Early Barremian or Late Hauterivian age is based on age determinations above and below.

$9810^{\prime}-9850^{\prime}$. From $9820^{\prime}$ the assemblages gradually become richer until $9870^{\prime}$. At $9810^{\prime}$ and $9820^{\prime}$ questionable specimens of Canningia cf. reticulata sensu Duxbury (1977) suggest that Upper Hauterivian strata are possibly penetrated, since this species is only known in the Upper Hauterivian - lowermost Barremian from Speeton (Duxbury 1977). At 9850' and in the subsequent samples Oligosphaeridium asterigerum is present and locally abundant. This species has a Hauterivian-Lower Barremian range at Speeton, but is recorded in younger strata in Northwestern Germany. This and the underlying sample include Oligosphaeridium sp. 1 which is restricted to this interval and was not recorded in the I-1 well. Oligosphaeridium sp. 1 is a distinct form. It is not known from on-shore sections and therefore cannot be used as an age-indicator.

Reworking of Upper Jurassic strata at $9830^{\prime}$ is indicated by Glossodinium dimorphum and Gochteodinia mutabilis, and reworking from the earliest Valanginian or Ryazanian is indicated at $9850^{\prime}$ and $9900^{\prime}$ by $E g$ montodinium torynum.

$9870^{\prime}-9900^{\prime}$. The age is assigned as Hauterivian, probably earliest Late Hauterivian or older, on the 
basis of the following downhole appearances: Gonyaulacysta cf. cladophora sensu Duxbury (1977) appears at $9870^{\prime}$ and is frequent here and in the underlying samples. This species is characteristic of the Lower Hauterivian (Davey 1979c, 1982a) although it is recorded as high as Lower Barremian by Duxbury (1977). At $9900^{\prime}$ Gonyaulacysta perforobtusa indicates an early Late Hauterivian (coeval to speetonensis Zone) or older age (Duxbury 1977). Cymososphaeridium validum also appears and has previously been reported from the Hauterivian of the North Sea (Davey 1982a). In this study it is also seen in the Lower Hauterivian at Speeton. The Hauterivian marker, Gonyaulacysta kostromiensis is consistently present, and locally abundant, from $9900^{\prime}$ and below. Both here and in the Adda- 1 well the highest occurrence of this species is unusually low compared to the on-shore range.

Reworking: The earliest Hauterivian marker Gochteodinia villosa subsp. multifurcata may be represented by single specimens of this species (subsp. indet.) at $9870^{\prime}$ and $9900^{\prime}$, but these are considered reworked since they only occur regularly from $10090^{\prime}$, and other earliest Hauterivian markers do not occur until below $10090^{\prime}$. A single Cannosphaeropsis thula at $9900^{\prime}$ is reworked from Upper Kimmeridgian-Ryazanian strata.

$9960^{\prime}-10020^{\prime}$. There is good evidence that Lower Hauterivian strata are penetrated at $9960^{\prime}$ since the first downhole occurrence of Nematosphaeropsis scala, a distinct marker of the lowermost Upper Hauterivian (speetonensis Zone) or older strata, and of Gonyaulacysta ordocava, previously only recorded from the Lower Hauterivian, take place here.

Reworking of Volgian or Ryazanian deposits is proven at $9960^{\prime}$ by Dingodinium spinosum. A single specimen of Sirmiodiniopsis frisia in this sample is also considered as reworked. Increased reworking of Volgian to Lower Valanginian sediments is indicated at $10020^{\prime}$ by Occisucysta evittii, Endoscrinium pharo, Tubotuberella apatela and Cannosphaeropsis thula.

$10090^{\prime}-10220^{\prime}$. The earliest Hauterivian (probably coeval to amblygonium Zone) - ?Late Valanginian age of this interval is clearly indicated by the downhole appearance of Gochteodinia villosa subsp. multifurcata and Phoberocysta tabulata at $10090^{\prime}$, of Lagenorhytis delicatula and Kleithriasphaeridium sp. 1 at 10 160', and of Muderongia extensiva, Isthmocystis distincta, Spiniferites ramosus subsp. primaevus, Muderongia sp. 1 and Pseudoceratium sp. 1 at $10220^{\prime}$. G. villosa subsp. multifurcata, Muderongia extensiva and Isthmocystis distincta are prominent earliest Hauterivian markers allowing safe interpretation of the age, despite the considerable amount of reworking in this part of the well. Muderongia sp. 1 and Pseudoceratium sp. 1 are not recorded on-shore above the Valanginian, but in the Adda-1 well they also make their first downhole occurrence together with Hauterivian markers.
The downhole appearance of Muderongia simplex at $10160^{\prime}$ is noteworthy. As mentioned in the previous section, this species seems to be rare in the uppermost Hauterivian and Barremian. The highest record of $M$. simplex in the Adda-1 well is also in the Hauterivian, although apparently in a younger part.

Since so little is known about the distribution of dinoflagellates in the Upper Valanginian in Northwestern Europe, it cannot be excluded that the interval between $10090^{\prime}$ and $10220^{\prime}$ may also include Upper Valanginian strata. However, the successive appearance of earliest Hauterivian markers throughout this interval favours a Hauterivian age.

Like above, a considerable amount of reworked Volgian to Lower Valanginian sediments is present in this interval. This is confirmed by three species having highest in situ occurrences in the Lower Valanginian, namely Tubotuberella apatela (rare), Aldorfia spongiosa (one specimen) and Occisucysta evittii. Also Egmontodinium expiratum, which has a known range of Middle Volgian to basal Ryazanian is reworked.

$10290^{\prime}-10470^{\prime}$. The Valanginian age, younger than earliest Valanginian Paratollia Zone, is based on the following events:

- The first downhole occurrence at $10290^{\prime}$ and the regular presence in the underlying samples of Surculosphaeridium sp. III of Davey (1982a) and of Muderongia simplex subsp. microperforata.

- The regular and common occurrence of Tubotuberella apatela from $10340^{\prime}$ and below.

- The presence of Batioladinium varigranosum at $10410^{\prime}$.

Of these species, Surculosphaeridium sp. III and T. apatela are regarded as most reliable Valanginian markers, while Batioladinium varigranosum is recorded on-shore also in the lowermost Hauterivian. The well defined first downhole appearance and regular occurrence beneath, of Surculosphaeridium sp. III and $T$. apatela is taken as evidence that these species are in situ and not reworked here.

Distinct markers of the lowermost Valanginian Paratollia Zone do not occur until the underlying interval, and the presence of a number of Ryazanian and Upper Jurassic species points to considerable reworking. Species considered reworked include:

- At $10290^{\prime}$ : Oligosphaeridium pulcherrimum sensu Ioannides et al. (1971), with a known range within the Kimmeridgian (Raynaud 1978, Davey 1982a).

- At 10 340': Glossodinium dimorphum (OxfordianMiddle Volgian, Woollam \& Riding 1983).

- At 10 410': Cannosphaeropsis thula (uppermost Kimmeridgian-Upper Ryazanian, Davey 1982a).

- At $10470^{\prime}$ : Cribroperidinium sp. A of Davey (1982a) (abundant in the Middle-Upper Volgian in Eastern England, Davey 1982a), Oligosphaeridium diluculum (Upper Ryazanian), Gochteodinia virgula (Middle-Upper Volgian), Batioladinium pomum (up- 
permost Volgian - Ryazanian), Dingodinium spinosum (Middle Volgian- top Ryazanian) and Perisseiasphaeridium pannosum, the precise Upper Jurassic range of which is uncertain.

The occurrence of three additional taxa in this interval deserves comments: There is a distinct highest occurrence of Ctenidodinium elegantulum in the Valanginian both in the I- 1 and the Adda- 1 wells. This top may be of local correlative value, although this species is known to range into the Lower Aptian on-shore.

The first downhole appearance of Dingodinium jurassicum in both I-1 and Adda-1 may also be a useful feature for correlation. $D$. jurassicum has previously been indicated to have a highest occurrence in the Middle Volgian (Raynaud 1978).

Chytroeisphaeridia cerastes, which is present at $10470^{\prime}$ and $10750^{\prime}$, is also recorded near the Ryazanian-Valanginian boundary at Speeton, and the range of this species, originally described from the Oxfordian, may therefore extend into the Valanginian.

$10530^{\prime}-10750^{\prime}$. The earliest Valanginian age of this interval is based on the first downhole appearance of in situ specimens of the earliest Valanginian marker Endoscrinium pharo at $10530^{\prime}$ and its regular occurrence in the samples below. Two additional species with highest occurrence in the Lower Valanginian also appear at 10 530': Sirmiodiniopsis frisia and Cymososphaeridium sp. I of Davey (1982a).

The occurrence of Occisucysta evittii at $10530^{\prime}$ is considered to be in situ since it is also present in most of the underlying samples. $O$. evittii, like $E$. pharo has a well documented youngest occurrence in the basal Valanginian Paratollia Zone at Speeton. Two further Early Valanginian and older species also appear at 10 570': Canningia compta and Surculosphaeridium sp. II of Davey (1982a).

Reworking of older sediments is still present, but in this interval appears to be less important than above: Cannosphaeropsis thula at $10530^{\prime}$ indicates reworking of uppermost Kimmeridgian- mid Ryazanian deposits. A single specimen of the top Ryazanian marker Dingodinium spinosum at $10730^{\prime}$ is also considered as reworked since this species is not consistently present and common until $10770^{\prime}$ and below.

$10770^{\prime}-10790^{\prime}$. The downhole appearance of several specimens of Dingodinium spinosum at $10770^{\prime}$ and the consistent presence of this species in the subsequent samples indicates the penetration of Ryazanian strata at this depth. Systematophora palmula, which also occurs in this sample, is only known with certainty to range from uppermost Ryazanian to lowermost Valanginian.

$10810^{\prime}-10970^{\prime}$. The regular occurrence of Cannosphaeropsis thula from $10810^{\prime}$ and below suggests that Lower Ryazanian strata are penetrated here, since $C$. thula is rare in the lower part of the Upper Ryazanian, but is consistently present and common in the Lower
Ryazanian in Eastern England (Davey 1982a). The presence of Egmontodinium expiratum at $10850^{\prime}$ also suggests an Early Ryazanian age, since the highest well established occurrence of this species is in the runctoni ammonite zone (Davey 1982a). However, the occurrence, also at $10850^{\prime}$, of Oligosphaeridium diluculum points to a Late Ryazanian (stenomphalus Zone) age, since this species is only recorded with certainty in this ammonite zone in Eastern England (Davey 1982a).

Based on this somewhat conflicting evidence, the age is given as undifferentiated Ryazanian.

$11000^{\prime}-11120^{\prime}$. The Early Ryazanian age of this interval is based on the downhole appearance of Stiphrosphaeridium dictyophorum at $11000^{\prime}$ and its abundance at $11060^{\prime}$. According to Davey (1982a) this species is very common in the Lower Ryazanian in Eastern England. The range of Batioladinium cf. varigranosum sensu Davey (1982a), only present at $11120^{\prime}$, is essentially Ryazanian.

Penetration of the Farsund Formation is almost certainly indicated at $11000^{\prime}$, although the top of this formation is defined at $11018^{\prime}$ on the basis of wire-line log patterns (Jensen et al. 1986). At $11000^{\prime}$ there is a strong increase in the amount of sapropelic organic matter. This is associated with a decrease in the dinoflagellate diversity and abundance of Tasmanites and Pterospermella, all features which usually mark penetration of the Farsund Formation (further discussed in connection with the Adda-1 well).

$11150^{\prime}-11300^{\prime}$. The Late Volgian age is based on the appearance of Gochteodinia virgula at $11150^{\prime}$, since this species is only known from the Middle and uppermost Volgian in Eastern England (Davey 1982a). Systematophora sp. I of Davey (1982a) is present at $11300^{\prime}$. Although this species occurs in the Lower Ryazanian in Eastern England, it is more frequent in the Volgian (Davey 1982a).

\section{The $M-8$ well}

Six side-wall cores spanning the Middle Volgian to Valanginian have been analysed from this well. The distribution of dinoflagellates and the interpreted age of the samples are shown in fig. 9.

\section{Discussion of ages}

\section{Side-wall core at $7300^{\prime}$}

Age: Valanginian, probably Early Valanginian. The assemblage includes several taxa which are characteristic of the Valanginian. The majority of these: Lagenorhytis delicatula, Hystrichosphaeridium scoriaceum, Aldorfia spongiosa and Pseudoceratium sp. 1 may possibly range into the Early Hauterivian, but are more well known from the Valanginian, and a pre-Hauterivian age is further supported by the absence of Hauterivian marker species. 
Tubotuberella apatela, which is common, and a questionable Sirmiodiniopsis frisia probably point to an Early Valanginian age.

Side wall core at $7400^{\prime}$

The Early Valanginian age is based on the presence of Surculosphaeridium sp. III of Davey (1982a) and Sirmiodiniopsis frisia. Exiguisphaera phragma, which ranges into the lowermost Hauterivian at Speeton, is only common in the Adda- 1 well in the lowermost Valanginian-Upper Ryazanian and supports an Early Valanginian age. A single Kleithriasphaeridium porosispinum is considered reworked, since other Ryazanian markers are absent.

Side-wall core at $7490^{\prime}$

The earliest Valanginian age is based on the highest record in this sample of Occisucysta evittii. Pareodinia sp. I of Davey (1982a) has previously been recorded in the interval assigned to the Late Ryazanian and Valanginian in the Haldager borehole (Davey 1982a). It is noteworthy that several specimens of Chlamydophorella trabeculosa were also recorded here. C. trabeculosa is not usually found below the Hauterivian although Davey (1982a: 7) considers that forms close to, or identical with, C. trabeculosa occur in the Valanginian.

The absence of Ryazanian markers points to a postRyazanian age.

Side-wall core at $7590^{\prime}$

Age: Ryazanian, probably equivalent to the kochi-stenomphalus Zones. The highest occurrence of the reliable top-Ryazanian markers Dingodinium spinosum and Gochteodinia villosa subsp. villosa are recorded here. Frequent Endoscrinium pharo also points to a Ryazanian age since this species barely continues into the earliest Valanginian. The frequent occurrence of Gonyaulacysta sp. A of Davey (1982a) and the absence of Muderongia simplex, Kleithriasphaeridium fasciatum, Pseudoceratium sp. 1, Achomosphaera neptunii, Phoberocysta tabulata and Spiniferites ramosus (all present in the sample at $7490^{\prime}$ ) clearly point to a prealbidum Zone age.

The sample is very rich in sapropelic organic matter which marks penetration of the Farsund Formation between this and the overlying sample.

Side-wall cores at $7700^{\prime}$ and $7800^{\prime}$

Age: Late part of Middle Volgian. The assemblages in the two samples include four distinct species whose concurrent ranges are restricted to the late part of the Middle Volgian: Dingodinium spinosum and Gochteodinia villosa make their stratigraphical first occurrence in the okusensis-anguiformis Zones (formerly giganteus Zone) (Davey 1979c, 1982a, Riding 1984), while Egmontodinium polyplacophorum and Ctenidodinium panneum become extinct above the oppressus Zone and anguiformis Zone respectively. The frequent occurrence of Cribroperidinium sp. A of Davey (1982a) supports this age assignment.

\begin{tabular}{|c|c|c|c|c|c|c|c|}
\hline $\begin{array}{c}\text { SIDE-WALL CORES } \\
\text { Legend: as fig. } 5 \\
\text { DGU } 0187 \mathrm{CHC}\end{array}$ & $\stackrel{0}{8}$ & 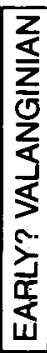 & 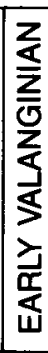 & 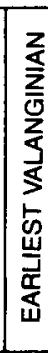 & 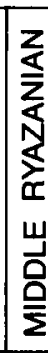 & & 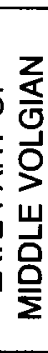 \\
\hline Formation & & & $\mathrm{ALH}$ & & & RSU & JND \\
\hline Depth (feet below KB) & & $\begin{array}{l}\text { 윳 } \\
\end{array}$ & 㝵 & $\frac{8}{2}$ & $\begin{array}{l}8 \\
\end{array}$ & 足 & 8 \\
\hline Facies: an=anoxic & & & & & ธิ & & 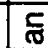 \\
\hline Cannosphaeropsis thula & & & & a. & & & - \\
\hline Glossodinium dimorphum & & & & & & a. & \\
\hline Cribroperidinium sp. A Davey $1982 a$ & & & & & & - & 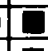 \\
\hline Egmontodinium polyplacophorum & & & & & & $\mathbf{0}$ & 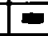 \\
\hline Systematophora sp. I Davey $1982 a$ & & & & & & $\boldsymbol{\sigma}$ & 口 \\
\hline Ctenidodinium panneum & & a. & & & & $\mathbf{0}$ & a. \\
\hline Oligosphaeridium diluculum & & & & & o. & & \\
\hline Gochteodinia villosa subsp. villosa & & & & & - & & $=$ \\
\hline Dingodinium spinosum & & & & & E & a. & - \\
\hline Tasmanites spp. & & & & & - & a & \\
\hline Canningia compta & & & & & a & & \\
\hline Gonyaulacysta sp. A Davey $1982 a$ & & & & & - & & \\
\hline Endoscrinium pharo & & & & & - & & \\
\hline Dingodinium tuberosum & & & & & $=$ & & \\
\hline Systematophora palmula & & & & a. & & & \\
\hline Perisseiasphaeridium pannosum & & & & a. & o. & & \\
\hline Pareodinia sp. I Davey $1982 a$ & & & & $=$ & & - & \\
\hline Occisucysta evittii & & & & - & - & & \\
\hline Chlamydophorella trabeculosa & & & & O & & & \\
\hline Systematophora cf. areolata sensu Davey 1982 & & & & - & & & \\
\hline Heslertonia heslertonensis & & & a. & - & & & \\
\hline Surculosphaeridium sp. I Davey 1982 & & & a. & & & & \\
\hline Kleithriasphaeridium porosispinum & & & - & & - & - & \\
\hline Exiguisphaera phragma & & & E & a & & & \\
\hline Endoscrinium granulatum & & & - & - & - & & \\
\hline Spiniferites multibrevis & & & E & D & & & \\
\hline Isthmocystis distincta & & & $\boldsymbol{E}$ & - & & & \\
\hline Occisucysta tentoria & & & - & - & & & \\
\hline Muderongia sp. 1 & & & - & - & & & \\
\hline Muderongia simplex & & & E & - & & & \\
\hline Hesiertonia pellucida & & & - & & & & \\
\hline Surculosphaeridium sp. III Davey 198 & & & - & - & & & \\
\hline Cassiculosphaeridia reticulata & & & - & & & & \\
\hline Cyclonephelium hystrix & & & $=$ & & & & \\
\hline Systematophora complicata & & & - & & & & \\
\hline Kleithriasphaeridium eoinodes & & & - & & & & \\
\hline Cribroperidinium? gigas & & a. & & & & & \\
\hline Sirmiodiniopsis frisia & & a. & $E$ & - & & & \\
\hline Tubotuberella apatela & & $\mathbf{E}$ & - & a. & $=$ & & a \\
\hline Hystrichodinium voigtii & & $\boldsymbol{\square}$ & D & E & a & a. & \\
\hline Pseudoceratium sp. 1 & & $\mathbf{E}$ & $\mathbf{D}$ & $\mathbf{E}$ & & & \\
\hline Hystrichosphaeridium scoriaceum & & E & $=$ & - & & & \\
\hline Trichodinium castanea & & $=$ & $\square$ & E & & & \\
\hline Achomosphaera? neptunii & & - & $=$ & $\mathbf{E}$ & & & \\
\hline Phoberocysta tabulata & & $=$ & $\mathbf{a}$ & $\mathbf{D}$ & & & \\
\hline Gonyaulacysta diutina - G. helicoidea group & & E & E & E & & & \\
\hline Endoscrinium campanula & & - & E & - & & & \\
\hline Kleithriasphaeridium fasciatum & & - & & - & & & \\
\hline Lagenorhytis delicatula & & - & & - & & & \\
\hline Sirmiodinium grossii & & - & $\boldsymbol{E}$ & & & & \\
\hline Fromea amphora & & E & $=$ & & & & \\
\hline Dingodinium jurassicum & & - & $=$ & & & & \\
\hline Aldorfia spongiosa & & $\mathbf{E}$ & & & & & \\
\hline Ctenidodinium elegantulum & & $=$ & & & & & \\
\hline Chlamydophorella nyei & & $\boldsymbol{\theta}$ & & & & & \\
\hline Wallodinium cylindricum & & - & & & & & \\
\hline Oligosphaeridium complex & & - & & & & & \\
\hline
\end{tabular}

Fig. 9. Dinoflagellates in side-wall cores of the $M-8$ well. 


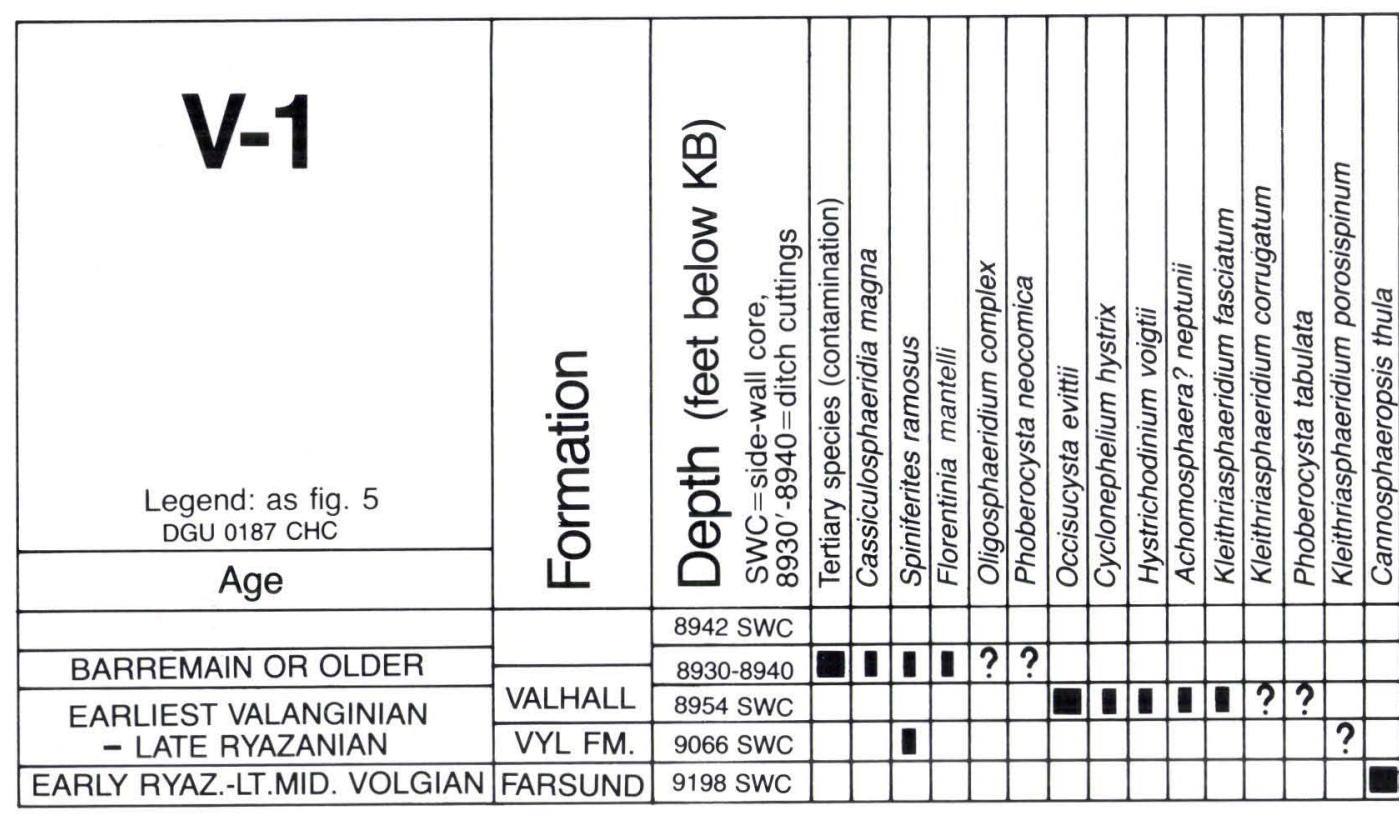

Fig. 10. Dinoflagellates in the $V-1$ well. The sample at $8942^{\prime}$ is palynologically barren.

\section{The $V$-1 well}

This is the only well in which the Vyl Formation is penetrated.

Only a poor quality set of palynological preparations were available for this study. The few dinoflagellates identified in these samples and the age determination are presented in fig. 10.

\section{Discussion of ages}

Side-wall core at $8942^{\prime}$. No dinoflagellates were recovered in the preparation from this sample.

Cutting sample at $8930^{\prime}-8940^{\prime}$. Cassiculosphaeridia magna indicates an age no younger than Barremian. If not caved, Florentinia mantellii probably points to a Barremian age.

Side-wall core at $8954^{\prime}$. The age is interpreted as latest Ryazanian or earliest Valanginian, based on the frequent Occisucysta evittii which is not recorded above the lowermost Valanginian, and the following species which are not recorded below the uppermost Ryazanian: Achomosphaera neptunii, Kleithriasphaeridium fasciatum, questionable $K$. corrugatum and questionable Phoberocysta tabulata.

Side-wall core at 9066'. The presence of several specimens of Spiniferites ramosus points to an age no older than Late Ryazanian. Only one published occurrence in pre-Valanginian deposits is known to the present author, namely an isolated Ryazanian record at Sklinnabanken, Norway (Aarhus et al. 1986).

Side-wall core at $9190^{\prime}$. Abundant Cannosphaeropsis thula indicates a Iate Middle Volgian - Early Ryazanian age.

\section{The E-1 well}

Two intervals have been investigated, from $9700^{\prime}$ to $9740^{\prime}$ covering the boundary between the Farsund and Valhall Formations (cutting samples), and 8181'$6^{\prime \prime}-8234^{\prime} 6^{\prime \prime}$ covering parts of the Tuxen and Sola Formations (core 7).

\section{Discussion of ages}

1. Upper Farsund and lower Valhall Formation Birkelund et al. (1983) have previously given a biostratigraphical account of the sequence from $9700^{\prime}$ to $9792^{\prime}$ on the basis of ammonites, bivalves and dinoflagellates. The material studied by them included core 8 (Farsund Formation) and three cutting samples (Farsund-Valhall Formation boundary). Core 8 was referred to the kochi Zone (Lower Ryazanian) on the basis of ammonites, while the three cutting samples were assigned a Valanginian age on the basis of dinoflagellates.

In the present study the above-mentioned cutting samples $\left(9700^{\prime}, 9720^{\prime}\right.$ and $\left.9740^{\prime}\right)$ were reinvestigated and the age is interpreted as being latest Ryazanian (probably equivalent to albidum Zone). The assemblages in the three samples are very similar and they are therefore discussed together.

The assemblage recorded by Birkelund et al. (1983) and in the present study is dominated by species characteristic of the Valanginian, but with known or assumed stratigraphical first occurrence in the uppermost Ryazanian albidum Zone. These species include in particular Pseudoceratium sp. 1, Phoberocysta tabulata, P. neocomica, Muderongia simplex, Kleithriasphaeridium fasciatum, Heslertonia heslertonensis and Ctenidodinium elegantulum. An earliest Valanginian or older age is indicated especially by Endoscrinium pharo and Occisucysta evittii, while several specimens of Dingodinium spinosum (not recorded by Birkelund et al. 1983) are reliable evidence of age no younger than the latest 
Ryazanian albidum Zone. D. spinosum is present in all three samples and for this reason it is not considerd as reworked. A latest Ryazanian age is therefore assumed. Gochteodinia villosa subsp. multifurcata and Surculosphaeridium sp. III of Davey (1982a) not previously recorded below the Lower Valanginian, are considered as caved.

2. Upper Tuxen and lower Sola Formation (core 7) Ten samples were processed palynologically. The distribution of dinoflagellates and the interpreted age are shown in fig. 11.

\section{Tuxen Formation}

Of the six samples processed, only one (at $8233^{\prime} 3^{\prime \prime}$ ), from the Munk Marl Bed, contained a few corroded dinoflagellates. The other five samples were palynologically barren. Only Cassiculosphaeridia magna was identified with certainty (known range: Upper Jurassictop Barremian).

\section{Sola Formation}

$8208^{\prime} 10^{\prime \prime}$. The age is probably middle Barremian. This sample includes three species regarded as reliable indicators of Barremian or older strata. Of these species Kleithriasphaeridium corrugatum is not recorded above the middle Barremian, while Cribroperidinium cornutum is restricted to the middle and Upper Barremian. The highest known record of Batioladinium longicornutum is at the top of the Barremian (for possible basal Aptian occurrence of top Barremian markers, see below). Although the sample is taken only $0.5 \mathrm{~m}$ above the base of the Sola Formation, reworking is not likely. The lower part of the Sola Formation consists of a laminated mudstone deposited under quiet conditions. On this basis, and since several specimens of $K$. corrugatum were found, it is unlikely, that they could be reworked.

$8200^{\prime}, 8194^{\prime}$ and $8191^{\prime} 6^{\prime \prime}$. Age: Barremian or possibly earliest Aptian (fissicostatus Zone). The age is based on the consistent presence of Batioladinium longicornutum which is a prominent top Barremian indicator. It should be noted, however, that no information of dinoflagellate distribution in the basal Aptian fissicostatus Zone of NW Europe is available, and $B$. longicornutum (like other species known up to the top of the Barremian) may possibly range into this lowermost Aptian Zone. The presence of typical Diphasiosphaera stolidota also points to a Barremian or fissicostatus Zone age. Phoberocysta neocomica, which is common, has not been recorded above the Lower Aptian forbesi Zone. It should finally be noted that none of the species known to have first occurrence in the Aptian on-shore are found in these samples.

The age determination of the Sola Formation given above is broadly in agreement with that based on calcareous nannoplankton (Thomsen in press), but differs

\begin{tabular}{|c|c|c|c|c|c|c|c|c|}
\hline $\begin{array}{l}\text { CORE } 7 \\
\text { Legend: as fig. } 5 \\
\text { DGU } 0187 \mathrm{cHC}\end{array}$ & & 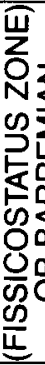 & 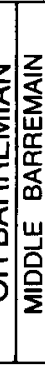 & & & & 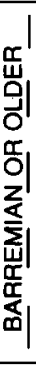 & \\
\hline Lithostratigraphy & \multicolumn{3}{|c|}{$\begin{array}{l}\text { SOLA } \\
\text { FORM. }\end{array}$} & \multicolumn{5}{|c|}{$\begin{array}{l}\text { TUXEN F. } \\
\text { MUNK MARL }\end{array}$} \\
\hline Driller's depth (below KB) & $\begin{array}{c}\overline{0} \\
\frac{1}{\infty} \\
\frac{1}{\infty}\end{array}$ & $\left.\frac{\$}{\infty}\right]$ & טై & $\underset{\infty}{\infty}$ & & & & 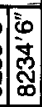 \\
\hline Muderongia staurota & & & & & & & c. & \\
\hline Cassiculosphaeridia magna & & & & & & & 鳥 & \\
\hline Kleithriasphaeridium fasciatum & & & a. & & & & & \\
\hline Kleithriasphaeridium corrugatum & & & E & & & & & \\
\hline Heslertonia heslertonensis & & & E & & & & c. & \\
\hline Cribroperidinium cornutum & & & E & & & & & \\
\hline Exiguisphaera plectilis & & & E & & & & & \\
\hline Muderongia sp. 1 & & & $=$ & & & & & \\
\hline Cerbia tabulata & & E & E- & & & & & \\
\hline Pseudoceratium pelliferum & & E & E & & & & & \\
\hline Trichodinium speetonense & & . & E & & & & & \\
\hline Hystrichodinium voigtii & & & 可 & & & & & \\
\hline Chlamydophorella membranoidea & & 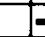 & 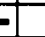 & & & & & \\
\hline Occisucysta tentoria & & $=$ & - & & & & & \\
\hline Chlamydophorella ordinalis & & ב & & & & & & \\
\hline Florentinia cooksoniae & - & - & & & & & & \\
\hline Batioladinium longicornutum & -1 & G & E & & & & & \\
\hline Odontochitina operculata & & & & & & & & \\
\hline Spiniferites ramosus & $\square$ & 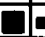 & E- & & & & & \\
\hline Chlamydophorella trabeculosa & E & E & $E$ & & & & & \\
\hline Phoberocysta neocomica & E & N. & G & & & & & \\
\hline Diphasiosphaera stolidota & er & c. & E- & & & & & \\
\hline Kleithriasphaeridium eoinodes & -1 & 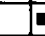 & E & & & & & \\
\hline Achomosphaera? neptunii & $\theta$ & - & E & & & & & \\
\hline Sirmiodinium grossii & -1 & E & - & & & & & \\
\hline Endoscrinium campanula & E & & E & & & & & \\
\hline Hystrichosphaerina schindewolfii & Q & & E & & & & & \\
\hline Dingodinium cerviculum & $\mathbf{E}$ & & $=$ & & & & & \\
\hline Subtilisphaera perlucida & -1 & E & & & & & & \\
\hline Prolixosphaeridium parvispinum & - & L & E & & & & & \\
\hline Florentinia mantellii & $\theta$ & -6 & 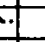 & & & & & \\
\hline Florentinia laciniata & r. & & & & & & & \\
\hline
\end{tabular}

Fig. 11. Dinoflagellates in core 7 of the E-1 well. The Tuxen Formation, apart from the Munk Marl Bed, is palynologically barren.

significantly from the age interpretation based on foraminifers in the same interval of the core (Buch 1969). According to Buch (1969) the age is early Late Aptian to Early Albian. This is based in particular on the presence of the foraminifers Valvulineria gracillima Ten Dam 1947 and a variety of Gavelinella intermedia which, according to Buch (1969), is known to range from the upper part of the Lower Aptian to the lowermost Albian. The reason for this considerable difference between dinoflagellate- and foraminifer-based age interpretations is not yet clear.

\section{The Adda-2 well}

Nearly $100 \mathrm{~m}$ of Upper Hauterivian to ?Upper Aptian strata were continuously cored (cores 1-4). Age deter- 


\begin{tabular}{|c|c|c|c|c|c|c|c|}
\hline & $\begin{array}{c}\text { Legend: as fig. } 5 \\
\text { DGU } 0187 \mathrm{CHC}\end{array}$ & 过 & 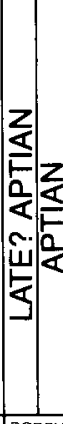 & 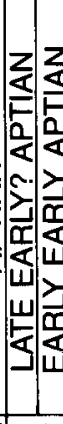 & & 悹 & \\
\hline & Formation & & $\begin{array}{l}\text { ROBOP } \\
\text { OR } \\
\text { SOLA }\end{array}$ & $\begin{array}{l}\text { SO- } \\
\text { LA }\end{array}$ & & JXEN & \\
\hline & $\begin{array}{l}\text { Driller's depth } \\
\text { (below KB) }\end{array}$ & & & & 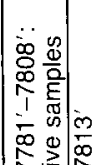 & 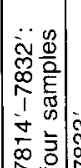 & 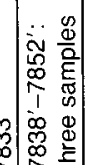 \\
\hline है & Simbirskites (Craspedod.) ct. got & schei & & & & 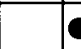 & \\
\hline & Simbirskites $\mathrm{sp}$. & & & & 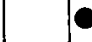 & & \\
\hline & Kleithriasphaeridium corrug & tum & & a & & & \\
\hline & $\begin{array}{l}\text { Wallodinium krutzschii } \\
\text { Florentinia cooksoniae }\end{array}$ & & & $\bar{z}$ & & & \\
\hline & Hystrichosphaerina schinde & & & $E$ & & & \\
\hline & Sirmiodinium grossii & & & E & & & \\
\hline & Maduradinium sp. A Davey & $982 a$ & & $E$ & & & \\
\hline & Phoberocysta neocomica & & & $=$ & & & \\
\hline & 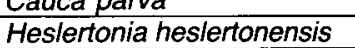 & & & a.k & & & \\
\hline & Fromea amphora & & & ter & & & \\
\hline & Kleithriasphaeridium eoinod & & & $=$ & & & \\
\hline & Dingodinium cerviculum & & & $\theta$ & & & \\
\hline & Hystrichodinium voigtii & & & 足 & & & \\
\hline & Ellipsodinium reticulatum & & & 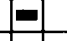 & & & \\
\hline & Achomosp & & & $\theta$ & & & \\
\hline & $\begin{array}{l}\text { Chlamydophorella trabeculos } \\
\text { Pseudoceratium pelliferum }\end{array}$ & & c. & a & & & \\
\hline$g$ & Kiokansium polypes & & E & - & & & \\
\hline & Cyclonephelium hystrix & & & & & & \\
\hline & Odontochitina operculata & & $J$ e & E[ & & & \\
\hline & Spiniferites ramosus & & D & 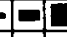 & & & \\
\hline & Cepadinium variabile & & a & $y=$ & & & \\
\hline & aera? neptunii & & - & & & & \\
\hline & $\begin{array}{l}\text { Wilgosphaeridium complex } \\
\text { Wallodinium analicum }\end{array}$ & & - & tat & & & \\
\hline & dium parvispin & & a & 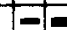 & & & \\
\hline & Florentinia laciniata & & - & -2 & & & \\
\hline & Callaiosphaeridium trycheriu & & E & E & & & \\
\hline & Ellipsodin. impertect. - Cass. reticul & & 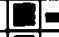 & - & & & \\
\hline & Aptea polymorpha - A. securigera & & $\square=$ & $\square$ & & & \\
\hline & idium asymme & tricum & & & & & \\
\hline & Floren & & & 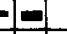 & & & \\
\hline & Cerbia tabulata & & 皮 & $1=$ & & & \\
\hline & Muderongia pariata & & a- & & & & \\
\hline & Spiniferites dentatus & & -1 & s. & & & \\
\hline & $m$ group & & 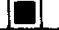 & k. & & & \\
\hline & Mudt & & - & & & & \\
\hline & Protoellipsodinium spinosun & & -1 & & & & \\
\hline & & & -1 & & & & \\
\hline & $a$ & & | & & & & \\
\hline
\end{tabular}

Fig. 12. Ammonites in cores 3-4 and dinoflagellates in core 1 of the Adda-2 well. The Tuxen Formation is palynologically barren.

mination in these cores have been carried out on the basis of ammonites in the Hauterivian and on the basis of dinoflagellates in the Aptian. All samples of the
Tuxen Formation were palynologically barren. Distribution of ammonites and dinoflagellates and the interpreted age of cores 1-4 are shown in fig. 12 .

\section{Discussion of ages}

Ammonites

The occurrence of the ammonites and the interpreted age are shown in fig. 12. The specimens were identified by Birkelund and Owen and are shown in plate 17, prepared by Birkelund. Simbirkites sp., occurring at $7812^{\prime} 6^{\prime \prime}-7813^{\prime}$, indicates the Upper Hauterivian, while Simbirskites (Craspedodiscus) cf. gottschei, at 7833'$7833^{\prime} 6^{\prime \prime}$, indicates the gottschei Zone (middle part of the Upper Hauterivian). According to Owen (written communication 1985), Simbirskites (Craspedodiscus) gottschei is restricted to its zone, which is represented both in Eastern England and Northern Germany, and in his opinion there is little doubt that the sediments containing $S$. cf. gottschei in Adda-2 can be correlated with this widely represented gottschei Zone interval.

\section{Dinoflagellates}

Tuxen Formation

Twelve samples were processed palynologically and proved essentially barren; no dinoflagellate species could be identified.

\section{Sola Formation}

In contrast to the Tuxen Formation well preserved dinoflagellates were recovered here.

$7774^{\prime}$. The common occurrence of Phoberocysta neocomica is a reliable marker of an Early Aptian (forbesi Zone) or older age. The absence of Batioladinium longicornutum and Diphasiosphaera stolidota, both occurring with $P$. neocomica in the lower part of the Sola Formation in the E-1 well, points to a younger age (equivalent to the fissicostatus or forbesi Zone) of the Sola Formation in Adda-2 than the cored part of this formation in E-1. Cepadinium variabile (not found in $\mathrm{E}-1$ ) is previously known only from the Lower Aptian forbesi to bowerbanki Zones of the Isle of Wight (Duxbury 1983).

$7762^{\prime}$. The age is probably late Early Aptian. The first occurrence of the Aptea polymorpha - A. securigera group takes place in this sample. Also of note is the presence of Chlamydophorella trabeculosa. The absence of Phoberocysta neocomica in this and the overlying samples points to an Aptian age, younger than the forbesi Zone, although typical $C$. trabeculosa is not recorded with certainty above the forbesi Zone. If the last occurrence of $P$. neocomica is a reliable feature for correlation, the first occurrence of the Aptea polymorpha - A. securigera group in the Central Trough must be delayed in comparison with the Isle of Wight where this group is known from the lowermost Aptian (forbesi Zone) to lowermost Albian (Duxbury 1983). The continued presence of Cepadinium variabile may possibly 
indicate an age no younger than the bowerbanki Zone, although the potential value of this species for correlation is not known.

\section{Sola or Rødby Formation}

The lower boundary of the Rødby Formation is placed at $7760^{\prime}$ by Jensen et al. (1986) but it should probably be placed above the cores, i.e. above $7750^{\prime}$, according to Jensen \& Buchardt (1986).

$7756^{\prime}$. The organic material in this sample is corroded, and the lack of good marker species allows no discrimination relative to ages below and above.

$7753^{\prime} 3^{\prime \prime}$. The age is Aptian, probably Late Aptian. Although the organic material is dominated by highly degraded, inertinitic particles, a rich and well preserved dinoflagellate assemblage was recovered here. The age is unquestionably Aptian, since Cerbia tabulata is abundant. Numerous Aptea polymorpha and $A$. securigera also show the age to be no younger than earliest Albian. Of importance for a more precise age determination is the presence of Cepadinium variabile, the Pterodinium aliferum group and of Stephodinium spinulosum as discussed in the following.
Cepadinium variabile points to an Early Aptian age no younger than the bowerbanki Zone, although the reliability of this species for correlation is unknown. On the other hand Stephodinium spinulosum and the Pterodinium aliferum group point to a Late Aptian age. $S$. spinulosum is only known from the uppermost Aptian jacobi and lowermost Albian tardefurcata Zones of the Isle of Wight (Duxbury 1983). However, S. spinulosum is very similar to Stephodinium daveyii, which is only known from the mid-Upper Aptian nutfieldiensis Zone in NW Germany (Below 1982d). It cannot be excluded that $S$. daveyii is present in older strata than the nutfieldiensis Zone, since in the section studied by Below (1982d), S. daveyii occurs from the base of the zone which unconformably overlies Barremian strata. The Pterodinium aliferum group is descibed from imprecisely dated Upper Aptian in Northwestern Germany by Eisenack (1958). Most evidence therefore favours a Late Aptian age, although the evidence is not conclusive.

The Aptian age determinations arrived at in Adda-2 on the basis of dinoflagellates are broadly in agreement with those based on calcareous nannoplankton (Thomsen in press). 


\section{Correlation of the studied wells}

The ages of the various lithological units and some of the seismostratigraphical units in the Danish Central Trough are outlined in this chapter. The lithological units are defined by Jensen et al. (1986) and the seismic units by Vejbæk (1986).

The analysis of only two complete sections, mainly on the basis of ditch cutting samples, with a few short supplementary sections is obviously an inadequate background for wide ranging generalisations, and the conclusions should therefore be regarded as preliminary.

\section{Chronostratigraphy}

The assumed positions of the Lower Cretaceous stages in the Adda-1 and I-1 wells are shown in fig. 13. The stages identified in the shorter sections are shown in figs. 9-12. The analysis leaves out the exact age of several intervals. It is clear, nevertheless, that the sediments in the Danish Central Trough represents all stages and most of the substages of the Lower Cretaceous. Within detection limits only local hiati are found, and none of the distinct lithological boundaries seem to be general unconformities.

The six Lower Cretaceous stages are represented by the Cromer Knoll Group and the upper part of the Farsund Formation. Fig. 13 shows that very thick deposits accumulated during early Early Cretaceous (Ryazanian-Early Hauterivian), while much thinner sequences were deposited during the late Early Cretaceous. The high accumulation rate took place during deposition of the upper Farsund Formation and most of the Valhall Formation. The Valhall Formation is interpreted to include gravity-flow deposition in several intervals (Jensen et al. 1986, Vejbæk 1986). The frequent occurrence of reworked dinoflagellates (especially in the I-1 well) supports this interpretation. The seismic stratigraphy shows that differential subsidence of basins took place in the Danish Central Trough during early Early Cretaceous (Gowers \& Sæbøe 1985, Vejbæk 1986).

The accumulation rate gradually decreased during the Hauterivian and Barremian. This tendency was accentuated during the Aptian and the highly condensed Rødby Formation, probably deposited during most of the Albian, marks the culmination of this development as evident from fig. 13. According to Vej- bæk (1986) the tectonic activity gradually decreased during the Early Cretaceous. This led to a more uniform subsidence of the Central Trough (although occasionally with events of inversion) from the Late Hauterivian. The deposits in the late Early Cretaceous were mainly marls and chalk oozes (Jensen et al. 1986).

\section{Age of lithological and seismostratigraphical units}

\section{The Farsund Formation-Valhall Formation boundary}

The uppermost samples of the Farsund Formation are in all cases of Ryazanian age. Most evidence favours a Late Ryazanian age, but the ages are somewhat different in the four sections studied. In Adda-1 and M-8 there is good evidence that the Farsund Formation ranges into the Upper Ryazanian, coeval to the Stenomphalus Zone. In M-8 the uppermost analysed sample of the Farsund Formation is $76^{\prime}$ below the top, leaving open the possibility of even younger strata within the formation. In E-1, ammonites of the uppermost Lower Ryazanian kochi Zone were identified by Birkelund et al. (1983). The kochi Zone was identified $56^{\prime}$ below the top of the Farsund Formation, allowing for a possible inclusion of Upper Ryazanian strata in the formation. A restudy of the cutting samples in the basal Valhall Formation in E-1 points to a latest Ryazanian age. If this new age determination is accepted it rules out the suggestion of Birkelund et al. (1983) that the Farsund Formation might here range into the Valanginian.

In I-1 the top of the Farsund Formation is interpreted to be of Early Ryazanian age. However, as the Ryazanian ages in the I-1 well are based on rather conflicting evidence, this age is somewhat uncertain. Pronounced reworking was found in the Valangian and it cannot be ruled out that the anomalously old ages near the Farsund-Valhall boundary could be due to the entire assemblage having been reworked.

Most evidence points to a Late Ryazanian age of the basal layers of the Valhall Formation (Adda-1, E-1). In M-8 the lowermost sample studied ( $24^{\prime}$ above the boundary) is dated as earliest Valangian, and it cannot be excluded that the basal part is Upper Ryazanian.

The fine biostratigraphical resolution of the Ryazanian-Lower Valangian supports the view that no unconformity is developed at the boundary between the Far- 


\section{I-1}



Fig. 13. The probable position of the Lower Cretaceous stages in the I-1 and the Adda-1 wells. The ages of uncoloured intervals are less certain. Also shown are lithostratigraphical subdivision, reflectors separating the seismic units LCA to LCF and the log-marker "A". Lithostratigraphy and seismic stratigraphy are from Jensen et al. (1986) and Vejbaek (1986). 
sund and Valhall Formations. The palynofacies change from mainly sapropelic (amorphous) organic matter in the upper Farsund Formation to mainly structured organic matter in the Valhall Formation points to a shift from an anoxic to a generally oxygenated bottom environment.

\section{Leek Member}

This basal member of the Valhall Formation is present in the Adda- 1 and I- 1 wells and the age of its base is discussed above (base of Valhall Formation). The top of the Leek Member in Adda-1 is in the lowermost Valanginian or Upper Ryazanian. In I-1 it is between samples dated as Late Ryazanian and samples dated as undifferentiated Ryazanian. This suggests a diachronous age of the top of this member, but it should be recalled that age determinations in this part of the I-1 well are less certain.

\section{Vyl Formation}

This formation is only drilled in the V-1 well (fig. 10), and the poor samples available for palynology only give uncertain ages; the following ages can nevertheless be interpreted: Twenty feet above the top a sidewall-core gives an earliest Valangian or latest Ryazanian age, while a sidewall-core within the formation ( $92^{\prime}$ below the top) is Late Ryazanian. Finally, a sidewall-core 82' below the base is most likely of Early Ryazanian age.

\section{Seismic units LCA, LCB, LCC, LCD and LCE}

The probable positions of these units in the I-1 and Adda-1 wells are shown in fig. 13. According to Vejbæk (pers. comm. 1985) it is very difficult to point out the precise depths of the unit boundaries, especially in the I-1 well. Too much emphasis should not, therefore, be placed on the biostratigraphical evaluation of these units.

Unit LCA is present in both wells and the presumed top falls in the thick sequence dated as lowermost Valanginian at both sites. Unit LCB is only present in the I-1 well where it is also in the lowermost Valangian. The biostratigraphical resolution is not fine enough to evaluate the possibility of an intra-earliest Valanginian hiatus at the LCA-LCC boundary in Adda-1.

The base of unit LCC is just below the biostratigraphically very distinct top of the lowermost Valanginian, and is therefore most likely isochronous between the two wells.

As evident from fig. 13, the base LCD-reflector may also be isochronous near the Valanginian - Hauterivian boundary in both I-1 and Adda-1.

Unit LCE, which is only drilled in the I-1 well (Vejbæk pers. comm.) falls in the interval dated as Upper Hauterivian to possibly Barremian. The base of the unit is close to the presumed Lower/Upper Hauterivian boundary. In Adda-1 the Hauterivian above lowermost Hauterivian is extremely thin, about $30^{\prime}$. It falls in the underlying seismic unit LCD, and the seismically suggested hiatus in the Upper Hauterivian is therefore plausible when comparing with the present biostratigraphical results.

Finer biostratigraphical resolution of this interval in the Adda- 1 well is achieved on the basis of calcareous nannofossils (Thomsen in press). It should be noted that Thomsen's (in press) results indicate a condensed, but continuous sedimentation across the boundary between the seismic units LCD and LCF.

\section{The Valhall Formation-Tuxen Formation boundary and seismic unit LCF}

The palynological results in the intervals containing this boundary in Adda-1 and I-1 are uncertain, and on the basis of the palynological study the boundary can only be placed somewhere in the Late Hauterivian - middle Barremian time interval. However, in core 4 from the Adda-2 well, the mid-Upper Hauterivian gottschei Zone is identified $21^{\prime}$ above the boundary by Birkelund (herein) on the basis of the index-fossil of the zone. This points to a mid-Late Hauterivian or older age for the basal part of the Tuxen Formation, and agrees with the results of Thomsen (in press). In Adda-1 and I-1 the calcareous nannofossils show a mid-Late Hauterivian age of the boundary and point to continuous sedimentation (Thomsen in press).

A seismic unit boundary (base of unit LCF) seems to coincide with the boundary between the Valhall and Tuxen Formations. The calcareous nannofossil results of Thomsen (in press) show this seismic reflector to be isochronous.

\section{The Tuxen Formation-Sola Formation boundary}

The dinoflagellate assemblages near this boundary include several marker species, allowing reliable ageassignments. Both in Adda-1 and I-1 the cutting samples at the top of the Tuxen Formation point to an age no younger than the middle Barremian. Core 5 of the Tuxen Formation in I-1 yielded less age-restricting species, and only allows a broader middle Barremian Early Aptian age determination, while the cores of this formation in Adda-2 and E-1 were barren of palynomorphs.

The earliest beds of the Sola Formation are determined to be of Barremian age in three of the four sections (Adda-1, I-1 and E-1) while in the Adda-2 core the age is determined as Early Aptian, both on the basis of calcareous nannofossils (Thomsen, pers. comm.) and dinoflagellates.

In I-1 a reliable top-Barremian marker, Cassiculosphaeridia magna, occurs in cutting samples $10^{\prime}$ and $36^{\prime}$ 
above the base of the Sola Formation, although a diverse middle Barremian assemblage is not met until in in the Tuxen Formation below.

In the core of E-1 a sample two feet above the boundary includes two Barremian markers, of which one, Kleithriasphaeridium corrugatum, marks the middle Barremian or older, while the overlying, cored part of the Sola Formation is Barremian or possibly lowermost Aptian (fissicostatus Zone). The calcareous nannofossils suggest a Late Barremian or possibly an Early Aptian age of the same level (Thomsen, pers. comm. 1986).

Summarizing these observations, it appears reasonable to place the earliest beds of the Sola Formation in the Upper Barremian, or possibly even middle Barremian. The biostratigraphy indicates that the Sola Formation in the Adda-2 well is younger than the cored lower part of this formation in E-1. This probably indicates a hiatus at the formation boundary in Adda-2.

\section{The boundary between the Sola and Rødby Formations}

In the I-1 well the uppermost beds in the Sola Formation occur in the interval reliably assigned as lowermost Albian or Aptian. Lowermost Albian may even be present $11^{\prime}$ above the boundary, but here the age determination is less certain. The lowermost Albian and Aptian is marked by a major change in the dinoflagellate assemblages as compared to the higher Albian. The age of the boundary is based on several of these species and therefore seems reliable.

In Adda-1 the uppermost sample dated as Albian (probably older than the youngest Albian dispar Zone, but still most likely Late Albian) is three feet below the top of the Sola Formation, according to the log-defined boundary. Even $13^{\prime}$ below the boundary the age still appears to be Late or Middle Albian. 23' below the boundary the Albian assemblage disappears, but top Aptian markers are not met until 53' below the boundary.

In comparison with the results from I-1, this suggests marked diachronism of the boundary between the Sola and Rødby Formations. However, caution should be exercised when interpreting the age of the boundary. Firstly, the overlying Rødby Formation is extremely thin (15' in Adda-1) and probably contains a condensed Albian sequence. Cavings from this part into older levels would lead to erroneously young ages if the in situ beds contain no age-diagnostic assemblages. Secondly, the wireline-log defined depth of the boundary may differ enough from the cutting depth to give a significantly younger age. Much more material, preferably from cores, would be necessary to evaluate the regional age of this boundary.

The thickness of the Rødby Formation is only $26^{\prime}$ in the I-1 well and $15^{\prime}$ in the Adda- 1 well. The single sample of the Rødby Formation in Adda-1 was barren, while the three samples in I-1 yielded assemblages suggesting a condensed sequence covering much of the Albian stage. Most or all of the Albian also seems to be represented by a condensed sequence in Adda-1, but here it apparently occurs in the uppermost Sola Formation, as discussed above.

\section{The Cromer Knoll Group-Chalk Group boundary}

This boundary occurs below samples referred to the Upper Cretaceous in both wells. The poor in situ assemblages above the boundary lack any of the topAlbian markers, but include Cyclonephelium membraniphorum, indicating a pre-Campanian age. This is weak evidence that the group boundary may coincide with the Lower-Upper Cretaceous boundary. 


\section{Systematics}

No detailed systematic study has been carried out in this project, and no new taxa are formally erected. Only brief descriptions of informally established forms found in the North Sea material, and remarks to some previously described species, are given below.

The alphabetical list (after genus) gives all taxa presented in the range charts and used for the biostratigraphical analysis. The generic allocation of dinoflagellate species follows Lentin \& Williams (1985). The numbers refer to the position in the two major range charts (A-numbers for the Adda-1 well and I-numbers for the I-1 well). Taxa for which systematic remarks are given are indicated with an asterisk. Plate and figure numbers are mentioned for taxa figured in plates 1-16.

\section{Organic-walled microplankton}

Except for Pterospermella Eisenack, 1972 and Tasmanites Newton, 1875, all taxa listed below are dinoflagellates (division Pyrrhophyta, class Dinophyceae Fritsch, 1929). Pterospermella and Tasmanites are classified with the green algae (division Prasinophyta Round, 1971, order Pterospermatales Schiller, 1925).

Achomosphaera? neptunii (Eisenack, 1958) Davey \& Verdier, 1966a (A 27, I 56) pl. 11, figs. 26-29

Achomosphaera ramulifera (Deflandre, 1937b) Evitt, 1963 (Adda-2)

Aldorfia spongiosa (McIntyre \& Brideaux, 1980) Davey, 1982a (A 112, I 151) pl. 9, fig. 7

Aldorfia sp. A Davey, 1982a (Adda-1, swc)

Aptea anaphrissa (Sarjeant, 1966c) Sarjeant \& Stover, 1978 (I 75)

*Aptea polymorpha Eisenack, 1958 - A. securigera Davey \& Verdier, 1974 group (A 20, I 22) pl. 4, figs. 13, 14, 17-19

Apteodinium grande Cookson \& Hughes, 1964 (A 12, I 52) pl. 9, figs. 8,9

Apteodinium granulatum Eisenack, 1958 (I-1, core 5)

Apteodinium nuciforme (Deflandre, 1938b) Stover \& Evitt, 1978 (Adda-1, swc)

Ascodinium scabrosum Cookson \& Hughes, 1964 (A 7, I 20) pl. 5, figs. 8, 9

Avellodinium falsificum Duxbury, 1977 (A 65, I 53) pl. 12, fig. 16

Batioladinium jaegeri (Alberti, 1961) Brideaux, 1975 (I 33) pl. 3, fig. 12
Batioladinium longicornutum (Alberti, 1961) Brideaux, 1975 (A 40, I 72) pl. 3, figs. 13-16

Batioladinium micropodum (Eisenack \& Cookson, 1960) Brideaux, 1975 (A 88)

Batioladinium? pelliferum (Alberti, 1961) Brideaux, 1975 (A 78, I 64) pl. 3, figs. 7-9

Batioladinium pomum Davey, 1982a (A 131, I 122) pl. 3 , figs. 10,11

Batioladinium radiculatum Davey, 1982a (I 121)

Batioladinium sp. I Davey, 1982a (A 89, I 119) pl. 2, figs. 20-22

Batioladinium varigranosum (Duxbury, 1977) Davey, 1982a (A 96, I 117) pl. 3, figs. 1, 2

Batioladinium cf. varigranosum sensu Davey, 1982a (A 116, I 145) pl. 3, figs. 3-6

*aff. Bourkidinium granulatum Morgan, 1975 (A 101, I 87) pl. 13, figs. 22-24

Callaiosphaeridium asymmetricum (Deflandre \& Courteville, 1939) Davey \& Williams, 1966b (A 25, I 32) pl. 12, figs. 18,19

Callaiosphaeridium trycherium Duxbury, 1980 (A 71, I 66) pl. 12, figs. 20, 21

Canningia compta Davey, 1982a (A 114, I 127) pl. 6, figs. 6,7

Canningia cf. reticulata sensu Duxbury, 1977 (I 74)

Cannosphaeropsis thula Davey, 1982a (A 137, I 137) pl. 11, figs. 19, 20, 25

Carpodinium granulatum Cookson \& Eisenack, 1962b (A 16, I 13) pl. 8, figs. 2-5

Carpodinium obliquicostatum Cookson \& Hughes, 1964 (A 8) pl. 8, fig. 1

Cassiculosphaeridia magna Davey, 1974 (A 49, I 48) pl. 8, figs. 16, 22, 23

${ }^{*}$ Cassiculosphaeridia reticulata Davey, 1969a (A 34, I 1) pl. 8, figs. 17-19

Cauca parva (Alberti, 1961) Davey \& Verdier, 1971 (I 11) pl. 6, figs. 3-5

Cepadinium variabile Duxbury, 1983 (Adda-2) pl. 5, figs. 1,2

Cerbia tabulata (Davey \& Verdier, 1974) Below, 1981a (A 21, I 73) pl. 4, figs. 9-11

${ }^{*}$ Chlamydophorella? membranoidea Vozzhennikova, 1967 (A 75, I 27) pl. 12, figs. 30, 31

*Chlamydophorella nyei Cookson \& Eisenack, 1958 (A 6, I 34) pl. 12, fig. 32

Chlamydophorella ordinalis (Davey, 1974) Davey, 1978 (E-1) 
* Chlamydophorella trabeculosa (Gocht, 1959) Davey, 1978 (A 29, I 82) pl. 12, figs. 27-29

Chytroeisphaeridia cerastes Davey, 1979d (I 123) pl. 8, figs. 6,7

Chytroeisphaeridia chytroeides (Sarjeant, 1962a) Downie \& Sarjeant, 1965 (A 105)

Coronifera oceanica Cookson \& Eisenack, 1958 (A 64, I 81) pl. 13, figs. 28, 29

Cribroperidinium boreas (Davey, 1974) Helenes, 1984 (A 37)

Cribroperidinium? cornutum Davey, 1974 (A 55, I 58) pl. 10, figs. $12,15-16$

* Cribroperidinium edwardsii (Cookson \& Eisenack, 1958) Stover \& Evitt, 1978 - C. orthoceras (Eisenack, 1958) Davey, 1969a group (A 23, I 36)

Cribroperidinium? gigas (Raynaud, 1978) Helenes, 1984 (A 142) pl. 10, fig. 13

Cribroperidinium sepimentum Neale \& Sarjeant, 1962 (A 84, I 97) pl. 10, fig. 14

Cribroperidinium sp. A Davey, 1982a (A 141, I 153) pl. 10, fig. 6

Ctenidodinium elegantulum Millioud, 1969 (A 99, I 113) pl. 12, figs. 2-4

Ctenidodinium panneum (Norris, 1965) Lentin \& Williams, 1973 (A 113, I 118) pl. 12, figs. 5, 11

Cyclonephelium hystrix (Eisenack, 1958) Davey, 1978 (A 22, I 21) pl. 4, figs. 12, 15, 16

Cyclonephelium membraniphorum Cookson \& Eisenack, 1962b (A 1, I 5)

Cymososphaeridium validum Davey, 1982a (I 91) pl. 14, fig. 20

Cymososphaeridium sp. I Davey, 1982a (A 94, I 125)

Dapsilidinium multispinosum (Davey, 1974) Bujak et al., 1980 (A 46, I 26) pl. 14, figs. 1-3

Diacanthum tenuiceras (Eisenack, 1958) Stover \& Evitt, 1978 (A 28, I 9) pl. 9, fig. 1

Dichadogonyaulax culmula (Norris, 1965) Loeblich \& Loeblich, 1968 (A 143, I 138)

* Dingodinium cerviculum Cookson \& Eisenack, 1958 (A 26, I 18) pl. 13, figs. 1-5

* Dingodinium jurassicum Cookson \& Eisenack, 1958 (A 103, I 104) pl. 13, figs. 6, 12

Dingodinium spinosum (Duxbury, 1977) Davey, 1979c (A 121, I 132) pl. 13, figs. 7-11

* Dingodinium tuberosum (Gitmez, 1970) Fisher \& Riley, 1980 (A 108, I 120) pl. 13, fig. 13

Dinopterygium cladoides Deflandre, 1935 (A 15, I 3)

Diphasiosphaera stolidota Duxbury, 1980 (A 43, I 131) pl. 11, figs. 21-24

Discorsia nanna (Davey, 1974) Duxbury, 1977 (A 67, I 96)

Egmontodinium expiratum Davey, 1982a (A 136, I 141) pl. 14, figs. 10-13

Egmontodinium polyplacophorum Gitmez \& Sarjeant, 1972 (M-8) pl. 14, fig. 14

Egmontodinium torynum (Cookson \& Eisenack, 1960b) Davey, 1979c (A 111, I 130) pl. 14, figs. 6-8
Ellipsodinium reticulatum Duxbury, 1980 (A 62) pl. 8, figs. 12,13

Ellipsodinium rugulosum Clarke \& Verdier, 1967 (I 10)

*Ellipsoidictyum imperfectum (Brideaux \& McIntyre, 1975) Lentin \& Williams, 1977b (A 63, I 17) pl. 8, figs. $20,21,24$

Endoscrinium campanula (Gocht, 1959) Vozzhennikova, 1967 (A 31, I 14) pl. 7, figs. 15, 16

Endoscrinium granulatum (Raynaud, 1978) Lentin \& Williams, 1981 (A 128) pl. 7, figs. 14, 17

Endoscrinium pharo Duxbury, 1977 (A 104, I 126) pl. 7, figs. $13,18,19$

Exiguisphaera phragma Duxbury, 1979a (A 115, I 61) pl. 9, figs. 2-4

Exiguisphaera plectilis Duxbury, 1980 (A 45) pl. 9, figs. 5,6

Fromea amphora Cookson \& Eisenack, 1958 (A 38, I 50) pl. 6, figs. 12,13

Fromea quadrugata Duxbury, 1980 (A 68, I 55) pl. 6, figs. 10,11

*Florentinia cooksoniae (Singh, 1971) Duxbury, 1980 (I 7) pl. 16, figs. 20,21

Florentinia laciniata Davey \& Verdier, 1973 (Adda-2, E-1) pl. 16, fig. 14

* Florentinia mantellii (Davey \& Williams, 1966) Davey \& Verdier, 1973 (A 44, I 16) pl. 16, figs. 15, 16, 18, 19

Glossodinium dimorphum Ioannides et al., 1977 (I 150)

Gochteodinia mutabilis (Riley in Fisher \& Riley, 1980) Davey, 1982a (I 149)

*Gochteodinia villosa subsp. multifurcata Davey, 1982a (A 100, I 101)

*Gochteodinia villosa subsp. villosa (Vozzhennikova, 1967) Norris, 1978 et subsp. indet. (A 107, I 102) pl. 2 , figs. 8, 11, 13-15, 18, 19

Gochteodinia virgula Davey, 1982a (I 146) pl. 2, figs. $12,16,17$

Gonyaulacysta cassidata (Eisenack \& Cookson, 1960) Sarjeant, 1966b (A 11) pl. 11, fig. 7

Gonyaulacysta centriconnata Riding, 1983 (A 138)

Gonyaulacysta cladophora sensu Duxbury, 1977 (I 88) pl. 10 , fig. 11

*Gonyaulacysta diutina Duxbury 1977 - G. helicoidea (Eisenack \& Cookson 1960) Sarjeant, 1966b group (A 58, I 35) pl. 10, figs. 2, 3

Gonyaulacysta exanguia Duxbury, 1977 (A 50, I 86) pl. 10 , fig. 1

Gonyaulacysta? fastigiata Duxbury, 1977 (A 87, I 77) pl. 10 , figs. 4,5

Gonyaulacysta jurassica (Deflandre, 1938b) Norris \& Sarjeant, 1965 (A 140, I 154)

Gonyaulacysta kostromiensis (Vozzhennikova, 1967) Sarjeant, 1969 (A 80, I 89) pl. 11, figs. 1-4

Gonyaulacysta ordocava Duxbury, 1977 (I 95) pl. 10, fig. 9

Gonyaulacysta? perforobtusa Duxbury, 1977 (I 90) pl. 10 , fig. 8 
Gonyaulacysta sp. A Davey, 1982a (A 127) pl. 10, fig. 7

Heslertonia heslertonensis (Neale \& Sarjeant, 1962)

Sarjeant, 1966b (A 59, I 69) pl. 12, figs. 12-15

Heslertonia pellucida Gitmez, 1970 (A 54, I 98) pl. 12, figs. $6-8$

${ }^{*}$ Hystrichodinium furcatum Alberti, 1961 (I 71)

${ }^{*}$ Hystrichodinium ramoides Alberti, 1961 (I 67) pl. 6, fig. 1

Hystrichodinium voigtii (Alberti, 1961) Davey, 1974 (A 5, I 46) pl. 6, figs. 2, 8, 9

Hystrichosphaeridium arborispinum Davey \& Williams, 1966b (I 78)

Hystrichosphaeridium scoriaceum Raynaud, 1978 (A 77, I 112) pl. 15, figs. 15-18

Hystrichosphaerina schindewolfii Alberti, 1961 (A 56, I 59) pl. 15, fig. 14

Isabelidinium gallium (Davey \& Verdier, 1973) Stover \& Evitt, 1978 (A 17) pl. 5. figs. 6, 7

Isthmocystis distincta Duxbury, 1979a (A 90, I 109) pl. 9, figs. 18-20

Kalyptea diceras Cookson \& Eisenack, 1960b (A 144)

Kiokansium polypes (Cookson \& Eisenack, 1962b) Davey, 1979b (I 12) pl. 13, figs. 25-27

Kleithriasphaeridium corrugatum Davey, 1974 (A 53, I $60)$ pl. 16, figs. 5-7

Kleithriasphaeridium eoinodes (Eisenack, 1958) Davey, 1974 (A 32, I 37) pl. 16, figs. 1-4

Kleithriasphaeridium fasciatum (Davey \& Williams, 1966b) Davey, 1974 (A 81, I 93) pl. 16, figs. 8, 13

Kleithriasphaeridium porosispinum Davey, 1982a (A 125) pl. 16, figs. 9-11

${ }^{*}$ Kleithriasphaeridium sp. 1 (A 82, I 105) pl. 16, figs. 12,17

Lagenorhytis delicatula (Duxbury, 1977) Duxbury, 1979b (A 91, I 103) pl. 8, figs. 8-11

Leberidocysta chlamydata (Cookson \& Eisenack, 1962b) Stover \& Evitt, 1978 (I 19) pl. 5, fig. 10

Leptodinium cancellatum Brideaux \& McIntyre, 1975 (I 30) pl. 8, figs. 14, 15

Litosphaeridium arundum (Eisenack \& Cookson, 1960) Davey, 1979b (A 9) pl. 14, fig. 5

Litosphaeridium conispinum Davey \& Verdier, 1973 (A 10)

Litosphaeridium siphoniphorum (Cookson \& Eisenack, 1958) Davey \& Williams, 1966b (A 13) pl. 14, fig. 4

Maduradinium? sp. A Davey, 1982a (A 48, I 40) pl. 5, figs. 11-13

Membranilarnacia polycladiata Cookson \& Eisenack in Eisenack, 1963a (I 38) pl. 5, figs. 14, 16, 17

Mendicodinium groenlandicum (Pocock \& Sarjeant, 1972) Davey, 1979c (A 120) pl. 12, fig. 1

Meristaulax granulata (Klement, 1960) Sarjeant, 1984a (Adda-1, swc)

Muderongia extensiva Duxbury, 1977 (I 108) pl. 1, figs. 1,3
Muderongia pariata Duxbury, 1983 (A 47, I 51) pl. 1, figs. 2, 4, 6, 8

Muderongia simplex Alberti, 1961 (A 74, I 106) pl. 1, figs. 9, 10

Muderongia simplex subsp. microperforata Davey, 1982a (A 92, I 114) pl. 1, fig. 7

Muderongia staurota Sarjeant, 1966c (A 69, I 63) pl. 1, fig. 5

Muderongia tetracantha (Gocht, 1957) Alberti, 1961 (A 72)

*Muderongia sp. 1 (A 83, I 107) pl. 2, figs. 1-4

Muderongia sp. A Davey, 1982a (Adda-1, swc)

Nannoceratopsis gracilis Alberti, 1961 (I 148)

Nematosphaeropsis scala Duxbury, 1977 (A 85, I 94) pl. 11, figs. 13,14

* Nematosphaeropsis sp. 1 (I 85) pl. 11, fig. 18

* Occisucysta evittii (Dodekova, 1969) Gitmez, 1970 (A 109, I 129) pl. 9, figs. 10-13

Occisucysta tentoria Duxbury, 1977 (A 61, I 39) pl. 9, figs. 14-17

Odontochitina operculata (O. Wetzel, 1933a). Deflandre \& Cookson, 1955 (A 4, I 28) pl. 1, fig. 11

Oligosphaeridium abaculum Davey, 1979a (I 76)

Oligosphaeridium asterigerum (Gocht, 1959) Davey \& Williams, 1969 (A 95, I 84) pl. 15, figs. 5, 6

Oligosphaeridium complex (White, 1842) Davey \& Williams, 1966b (A 14, I 15) pl. 15, figs. 7, 10

Oligosphaeridium diluculum Davey, 1982a (A 124, I 139) pl. 15, fig. 4

Oligosphaeridium perforatum (Gocht, 1959) Davey \& Williams, 1969 (I 83)

Oligosphaeridium prolixispinosum Davey \& Williams, 1966b (I 2) pl. 15, fig. 1

Oligosphaeridium pulcherrimum sensu Davey, 1982b (I 24)

Oligosphaeridium pulcherrimum sensu Ioannides et al., 1977 (I 152)

Oligosphaeridium sp. GE McIntyre \& Brideaux, 1980 (A 135, I 100) pl. 15, fig. 2

*Oligosphaeridium sp. 1 (I 79) pl. 15, fig. 3

Palaeoperidinium pyrophorum (Ehrenberg, 1838) Sarjeant, 1967b (I 6)

Pareodinia ceratophora Deflandre, 1947c (A 145)

*Pareodinia sp. 1 (I 25) pl. 4, figs. 1-4

Perisseiasphaeridium pannosum Davey \& Williams, 1966b (A 122, I 144)

*Phoberocysta neocomica (Gocht, 1957) Millioud, 1969 (A 35, I 43) pl. 2, figs. 9, 10

*Phoberocysta tabulata Raynaud, 1978 (A 73, I 99) pl. 2, figs. 5-7

Prolixosphaeridium granulosum sensu Ioannides et al., 1977 (A 123)

Prolixosphaeridium parvispinum (Deflandre, 1937b)

Davey et al., 1969 (A 42, I 44) pl. 13, figs. 19-21

Protoellipsodinium clavulum Davey \& Verdier, 1971 (I

23) pl. 13, 14, 16 
Protoellipsodinium spinosum Davey \& Verdier, 1971 (A 36, I 45) pl. 13, figs. 17, 18

Psaligonyaulax deflandrei Sarjeant, 1966b (A 18)

Pseudoceratium pelliferum Gocht, 1957 (A 39, I 54) pl. 3 , figs. 17-20

*Pseudoceratium sp. 1 (A 93, I 110) pl. 3, figs. 21-24

*Pterodinium aliferum Eisenack, 1958 group (Adda-2) pl. 11, figs. 11,16

Pterodinium premnon Duxbury, 1980 (A 79)

Pterospermella Eisenack, 1972, spp. (A 3, I 49) pl. 6, figs. $18-20$

Rhynchodiniopsis aptiana Deflandre, 1935 (A 60) pl. 10 , fig. 10

Senoniasphaera jurassica (Gitmez \& Sarjeant, 1972) Lentin \& Williams, 1976 (A 133) pl. 5, figs. 23, 24

Sirmiodiniopsis frisia (Raynaud, 1978) Lentin \& Williams, 1981 (A 106, I 124) pl. 7, figs. 1-5

Sirmiodinium grossii Alberti, 1961 (A 33, I 42) pl. 7, figs. 6-9

*Spiniferites? dentatus (Gocht, 1959) Lentin \& Williams, 1973 (A 76, I 41) pl. 11, figs. 5, 6, 9, 10

* Spiniferites ramosus (Ehrenberg, 1838) Loeblich \& Loeblich, 1966 - S. multibrevis (Davey \& Williams, 1966a) Below 1982c group (A 2, I 8)

Spiniferites ramosus subsp. primaevus Duxbury, 1977 (A 86, I 111) pl. 11, fig. 15

Spiniferites speetonensis Duxbury, 1980 (A 70, I 62) pl. 11 , fig. 8

Stephodinium coronatum Deflandre, 1936a (A 51, I 29) pl. 12, figs. 24-26

* Stephodinium spinulosum Duxbury, 1983 (Adda-2) pl. 12 , fig. 23

* Stiphrosphaeridium anthophorum (Cookson \& Eisenack, 1958) Davey, 1982a - S. dictyophorum (Cookson \& Eisenack, 1958) Davey, 1982a group (A 129, I 31) pl. 15 , figs. $8,9,12,13$

Stiphrosphaeridium arbustum Davey, 1982a (A 130) pl. 15, fig. 11

Subtilisphaera? paeminosa (Drugg, 1978) Bujak \& Davies, 1983 (I 143)

Subtilisphaera perlucida (Alberti, 1959b) Jain \& Millepied, 1973 (A 41) pl. 5, fig. 5

Subtilisphaera ventriosa (Alberti, 1959b) Jain \& Millepied, 1973 (A 24, I 47) pl. 5, figs. 3, 4

Surculosphaeridium sp. I Davey, 1982a (A 110) pl. 14, fig. 19

Surculosphaeridium sp. II Davey, 1982a (I 128) pl. 14, fig. 18

Surculosphaeridium sp. III Davey, 1982a (A 97, I 115) pl. 14, figs. 15-17

Systematophora cf. areolata sensu Davey, 1982a (A 119, I 140) pl. 14, figs. 9, 21

Systematophora complicata Neale \& Sarjeant, 1962 (I 92) pl. 14, fig. 22

Systematophora palmula Davey, 1982a (A 117, I 133)

Systematophora vestita (Deflandre, 1938b) Davey, 1982a (A 118, I 136)
Systematophora sp. I Davey, 1982a (A 139, I 147)

Taleisphaera hydra Duxbury, 1979a (I 80) pl. 12, figs. 17,22

Tasmanites Newton, 1875, spp. (A 19, I 4) pl. 6, figs. 14-17

Trabeculodinium quinquetrum Duxbury, 1980 (I 68) pl. 11, figs. 12,17

Trichodinium castanea (Deflandre, 1935) Clarke \& Verdier, 1967 (A 30, I 70) pl. 4, figs. 5-7

Trichodinium speetonense Davey, 1974 (A 52, I 57) pl. 4 , fig. 8

Tubotuberella apatela (Cookson \& Eisenack, 1960b) Ioannides et al., 1977 (A 98, I 116) pl. 7, figs. 10-12

Valensiella ovula (Deflandre, 1947c) Eisenack, 1963a (A 126) pl. 12, figs. 9, 10

Wallodinium anglicum (Cookson \& Hughes, 1964) Lentin \& Williams, 1973 (A 57, I 65) pl. 5, figs. 15, 18,22

Wallodinium cylindricum (Habib, 1970) Duxbury, 1983 (A 102, I 135) pl. 5, figs. 19-21

Wallodinium krutzschii (Alberti, 1961) Habib, 1972 (A 134, I 134)

Genus Aptea Eisenack, 1958; emend. Davey \& Verdier, 1974; emend. Dörhöfer \& Davies, 1980

Aptea polymorpha Eisenack, 1958 - A. securigera Davey \& Verdier, 1974 group

Pl. 4, figs. 13, 14, 17-19

In the present material a continuous gradation between Aptea polymorpha and $A$. securigera is observed, although most specimens may be referred to $A$. securigera. Since the two species appear to have the same stratigraphical range they have been grouped together.

\section{Genus Bourkidinium Morgan, 1975}

aff. Bourkidinium granulatum Morgan, 1975

Pl. 13, figs. 22-24

The specimens bear precingular processes, while the equatorial zone is devoid of processes. In this morphology they are intermediate between Bourkidinium granulatum, which only bears processes in the apical and antapical region, and Tanyosphaeridium regulare Davey \& Williams, 1966b, with uniformly distributed processes. The latter species occurs in the North Sea material together with aff. Bourkidinium granulatum, but is not included in the present study.

\section{Genus Cassiculosphaeridia Davey, 1969a}

Cassiculosphaeridia reticulata Davey, 1969a

Pl. 8, figs. 17-19 
Cassiculosphaeridia reticulata and Ellipsoidictyum imperfectum (Brideaux \& McIntyre, 1975) Lentin \& Williams, 1977b) are shown separately in the range charts of Adda-1 and I-1 (figs. 5,7). However, this caused difficulties; the material here studied shows a continuous transition in morphology between the two species with many intermediate forms, and distinction between the two species in the two wells is therefore not entirely reliable. In Adda-2 the two species are grouped together (fig. 12).

\section{Genus Chlamydophorella Cookson \& Eisenack, 1958; emend. Duxbury, 1983}

Chlamydophorella? membranoidea Vozzhennikova, 1967

Pl. 12, figs. 30,31

This species is distinguished from Chlamydophorella nyei by the presence of a corona. In the present material, the corona is usually indistinct and can often only be seen at $\times 1000$ magnification. It is likely that several unfavourably oriented specimens of $C$.? membranoi$d e a$, without visible corona, have been included in $C$. nyei in the range charts.

Chlamydophorella nyei Cookson \& Eisenack, 1958 Pl. 12, fig. 32

See remarks to Chlamydophorella trabeculosa.

Chlamydophorella trabeculosa (Gocht, 1959) Davey, 1978

Pl. 12, figs. 27-29

Typical C. trabeculosa can be clearly distinguished from typical Chlamydophorella nyei Cookson \& Eisenack, 1958 , by development of the apical horn and the processes. In $C$. trabeculosa the horn is long and the processes are thin (thread-like, massive?) while in $C$. nyei the horn is short and the processes are wider and sometimes hollow. Specimens with long horns like C. trabeculosa, but with wide and hollow processes, like in $C$. nyei occur in the Upper Aptian on the Isle of Wight (Batten 1980, pl. 1, fig. 1, Duxbury 1983, pl. 3, fig. 10). Delimitation of the two species is therefore questionable. In the present work the Upper Aptian forms mentioned are allocated with $C$. nyei, following Duxbury (1983).

Genus Cribroperidinium Neale \& Sarjeant, 1962; emend. Davey, 1969a; emend. Sarjeant, 1982; emend. Helenes, 1984
Cribroperidinium edwardsii (Cookson \& Eisenack, 1958) Stover \& Evitt, 1978 - C. orthoceras (Eisenack, 1958) Davey, 1969a group

The two species seem to differ only in minor details in their development of the parasutural ridges and no distinction between them has been attempted in the present study.

Genus Dingodinium Cookson \& Eisenack, 1958; emend. Mehrotra \& Sarjeant, 1984b

Dingodinium cerviculum Cookson \& Eisenack, 1958 Pl. 13, figs. 1-5

Following Mehrotra \& Sarjeant (1984b), Dingodinium albertii Sarjeant, 1966 is considered to be a junior synonym of Dingodinium cerviculum. D. cerviculum was originally described from Australia. The European specimens are generally distinctly smaller and have previously been classified with Dingodinium albertii by most workers. Specimens recovered in the present study are closely comparable in size to " $D$. albertil". The study of Mehrotra \& Sarjeant (1984b) shows, however, that the size-dependant separation of the two species is untenable.

Dingodinium jurassicum Cookson \& Eisenack, 1958 Pl. 13, figs. 6-12

In the present study specimens without a clearly marked apical horn, but otherwise similar to Dingodinium cerviculum, are included in $D$. jurassicum. It sometimes proved difficult to separate the two species since forms with very short horns are also present in the material.

Dingodinium tuberosum (Gitmez, 1970) Fisher \& Riley, 1980

Pl. 13, fig. 13

Specimens showing parasutural lines on the periphragm, but otherwise similar to Dingodinium jurassicum, are classified with D. tuberosum.

\section{Genus Ellipsoidictyum Klement, 1960}

Ellipsoidictyum imperfectum (Brideaux \& McIntyre, 1975) Lentin \& Williams, 1977b

P1. 8, figs. $20,21,24$

See remarks to Cassiculosphaeridia reticulata. 
Genus Florentinia Davey \& Verdier, 1973; emend. Duxbury, 1980

Florentinia cooksoniae (Singh, 1971) Duxbury, 1980 Pl. 16, figs. 20, 21

In the range charts for the Adda- 1 and I- 1 wells some of the specimens classified as Florentinia mantellii should perhaps be classified with $F$. cooksoniae. The two species are closely related and it may often be difficult to distinguish between them (e.g. pl. 16, figs. 15, 16). Typically the processes in $F$. cooksoniae are simple, while some of the processes in $F$. mantellii are distally divided.

Florentinia mantellii (Davey \& Williams, 1966) Davey \& Verdier, 1973

Pl. 16, figs. 15, 16, 18, 19

See remarks to Florentinia cooksoniae.

\section{Genus Gochteodinia Norris, 1978}

Gochteodinia villosa (Vozzhennikova, 1967) Norris, 1978

G. villosa subsp. multifurcata Davey, 1982a

Pl. 2, figs. 18,19

See remarks below

G. villosa subsp. villosa and subsp. indeterminate

Pl. 2, figs. 8, 11, 13-15

The two subspecies of $G$. villosa, subsp. multifurcata and subsp. villosa, are distinguished on the distal extremity of the processes: In subsp. multifurcata at least three distal spines are developed at some of the processes, while in subsp. villosa the processes are typically acuminate, but may briefly bifurcate. In the present study only specimens clearly showing the diagnostic process endings are classified with subspecies multifurcata. In the Adda-1 and I-1 wells specimens of $G$. villosa, which could not be identified at the subspecies level, were grouped together with undoubted subspecies villosa.

Genus Gonyaulacysta Deflandre, 1964; emend. Sarjeant, 1969; emend. Stover \& Evitt, 1978; emend. Sarjeant, 1982

Gonyaulacysta diutina Duxbury, 1977 - G. helicoidea (Eisenack \& Cookson, 1960) Sarjeant, 1966b group Pl. 10, figs. 2, 3
According to Duxbury (1977), G. diutina is closely comparable with specimens referred by Sarjeant (1966a) to Gonyaulacysta helicoidea, although they are separable on general cyst outline and size. A comparison of $G$. diutina with the type material of $G$. helicoidea, as illustrated in Eisenack \& Cookson (1960), shows even greater similarity, and in the present writers opinion, $G$. diutina should probably be considered as a junior synonym of $G$. helicoidea.

Genus Hystrichodinium Deflandre, 1935; emend. Sarjeant, 1966b; emend. Clarke \& Verdier, 1967

Hystrichodinium furcatum Alberti, 1961

See remarks below.

Hystrichodinium ramoides Alberti, 1961

Pl. 6, fig. 1

$H$. ramoides and $H$. furcatum are closely related species. Both have distally furcated processes; in $H$. furcatum the processes are only divided once, usually giving rise to two short branches, while in $H$. ramoides the distal end is more complexly branched (some of the branches are again split into "twigs").

\section{Genus Kleithriasphaeridium Davey, 1974}

Kleithriasphaeridium sp. 1

Pl. 16, figs. 12, 17

This form differs from $K$. fasciatum (Davey \& Williams, 1966) Davey, 1974 and $K$. corrugatum Davey, 1974 in the presence of membraneous lateral connections between some of the processes. In $K$. fasciatum and $K$. corrugatum the processes are free. In other characters, especially in the longitudinal ribbing of the processes and membranes, Kleithriasphaeridium sp. 1 is closely comparable to $K$. corrugatum and $K$. fasciatum.

\section{Genus Muderongia Cookson \& Eisenack, 1958}

\section{Muderongia sp. 1}

Pl. 2, figs. $1-4$

1959 Dinoflagellat gen. et sp. indet. (1) - Gocht, p. 52, pl. 5, figs. 4-6

1961 Muderongia sp. A - Alberti, p. 13, pl. 2, figs. 10, 11

This form is intermediate between Muderongia simplex, which is devoid of processes, and Phoberocysta tabulata having many parasutural processes. Muderongia sp. 1 is ornamented with fine sutural lines. A small number of spines arise from these sutures. 


\section{Genus Nematosphaeropsis Deflandre \& Cookson, 1955}

Nematosphaeropsis sp. 1

Pl. 11, fig. 18

Only a single specimen has been seen. It is smoothwalled with strong gonal and some intergonal processes, connected proximally by relatively high parasutural septa. The processes are distally furcate (usually trifurcate) with bifid endings. In several cases thin trabeculae are seen to connect the endings of adjacent processes. This form basically conforms to the architecture of Trabeculodinium quinquetrum Duxbury, 1980, from which it differs in the possession of distinct parasutural septae.

\section{Genus Occisucysta Gitmez, 1970}

Occisucysta evittii (Dodekova, 1969) Gitmez, 1970 Pl. 9, figs. 10-13

Specimens classified as Occisucysta cf. evittii and Occisucysta sp. A in Davey $(1979,1982 \mathrm{a})$ are here considered to be within the morphological range of $O$. evittii.

\section{Genus Oligosphaeridium Davey \& Williams, 1966b; emend. Davey, 1982a}

\section{Oligosphaeridium sp. 1}

Pl. 15, fig. 3

This form appears to be similar to Oligosphaeridium asterigerum (Gocht, 1959) Davey \& Williams, 1969, except for the presence of long, fine and irregular, occasionally branching, threads arising from the spines in the distal end of the processes. In some instances the fine threads are seen to connect two processes. Most, or all, of the delicate threads may be broken trabeculae between processes. Unfortunately most specimens observed have been damaged, preventing more precise description of this distinct form.

Genus Pareodinia Deflandre, 1947c; emend. Gocht, 1970b; emend. Johnson \& Hills, 1973; emend. Wiggins, 1975; emend. Stover \& Evitt, 1978

Pareodinia sp. 1

Pl. 4, figs. 1-4

1982b Pareodinia sp. - Davey, pl. 6. 3-6, fig. 7

This species is finely gran lar $_{\text {and }}$ posesses an apical horn of short to moderate length. The archaeopyle is intercalary; the number of opercular plates is uncertain. Pareodinia sp. in Davey (1982b) is similar, except for being considerably larger, judging from the photographed specimen. Pareodinia sp. I in Davey (1982a) differs in having a generally longer, more abrubtly rising apical horn.

\section{Genus Phoberocysta Millioud, 1969}

Phoberocysta neocomica (Gocht, 1957) Millioud, 1969 Pl. 2, figs. 9, 10

See comments below.

Phoberocysta tabulata Raynaud 1978

Pl. 2, figs. 5-7

This species is differentiated from $P$. neocomica by its far better expressed paratabulation. However, incipient paratabulation may also be developed in $P$. neocomica as can be seen in text-fig. 7 in Gocht (1957) which shows the dorsal surface of the holotype. Continuous gradation of morphologies between the two species has been observed in the present material.

\section{Genus Pseudoceratium Gocht, 1957; emend. Dörhöfer \& Davies, 1980}

Pseudoceratium sp. 1

Pl. 3, figs. 21-24

$\begin{array}{ll}1979 \text { c } & \text { Pseudoceratium pelliferum - Davey, pl. 4, fig. } 1 \\ \text { 1982a } & \text { Pseudoceratium pelliferum (early representative) - Davey, pl. } \\ & \text { 10, fig. } 16\end{array}$

This form, which should only be regarded as a variety of Pseudoceratium pelliferum Gocht, 1957, is recognized by much shorter horns than in typical individuals of $P$. pelliferum.

Genus Pterodinium Eisenack, 1958; emend. Yun, 1981

Pterodinium aliferum Eisenack, 1958 group

Pl. 11, figs. 11,16

This group includes Pterodinium aliferum and the forms figured in Eisenack (1958, pl. 24, figs. 7-9) as Pterodinium sp. and Pterodinium? These forms have more irregular septa than $P$. aliferum. 
Genus Spiniferites Mantell, 1850; emend. Sarjeant, 1970

Spiniferites? dentatus (Gocht, 1959) Lentin \& Williams, 1973; emend. Duxbury, 1977

Pl. 11, figs. 5, 6, 9, 10

Intermediate forms between S.? dentatus and Spiniferites multibrevis (Davey \& Williams, 1966a) Below, 1982 c occur in the Lower Valanginian at Speeton and have also been seen in the North Sea samples (e.g. pl. 11, fig. 5). These intermediate forms have parasutural crests of only low to moderate height, in contrast to the high crests in $S$. dentatus. On the other hand they resemble $S$. dentatus in bearing a larger number of processes arising from the parasutural crests than are present in S. multibrevis.

Spiniferites ramosus (Ehrenberg, 1838) Loeblich \& Loeblich, 1966 - S. multibrevis (Davey \& Williams, 1966a) Below, 1982c group

For convenience $S$. ramosus and the closely related species $S$. multibrevis (formerly classified as a subspecies of $S$. ramosus) are treated as a group in the range charts of the Adda-1 and I-1 wells. Only one subspecies of $S$. ramosus, namely subsp. primaevus Duxbury, 1977 has been kept separate since it is both morphologically and stratigraphically distinct.

Genus Stephodinium Deflandre, 1936a; emend. Davey, 1970
Stephodinium spinulosum Duxbury, 1983

Pl. 12, fig. 23

This species is very similar to Stephodinium daveyii Below, 1982. The main difference between the two species is the presence of an apical pericoel in S. $d a$ veyii, which apparently lacks in S. spinulosum. Furthermore, the parasutural ridges and processes, present in both species, appear to be slightly better developed in $S$. spinulosum than in $S$. daveyii.

\section{Genus Stiphrosphaeridium Davey, 1982a}

Stiphrosphaeridium anthophorum (Cookson \& Eisenack, 1958) Davey, 1982a - S. dictyophorum (Cookson \& Eisenack, 1958) Davey, 1982a group

Pl. 15, figs. $8,9,12,13$

The two species $S$. anthophorum and $S$. dictyophorum are basically similar, but the differences in their morphology have been clarified by Davey (1982a); thus $S$. anthophorum has wider and more fenestrate processes than $S$. dictyophorum. Strictly following this criterion for separation, it appears that both species occur at two discrete stratigraphical levels, namely near the JurassicCretaceous boundary and in the Upper Aptian (further accounted for in a previous section, p. 20). Since it was realized during this study that many specimens with an intermediate morphology cannot easily be identified with one particular species of the two, they have been treated as a single group. 


\section{Acknowledgements}

Tove Birkelund, who died in 1986, had a major influence on the initiation of the Jurassic-Lower Cretaceous project and was a dynamic and inspiring member of the working group. She is especially acknowledged for arranging and participating in sampling trips to English Jurassic and Lower Cretaceous sections, and for her encouragement during the author's stay at the Institute of Historical Geology and Paleontology, Copenhagen University, in 1983.

John W. Neale, University of Hull, is thanked for his valuable help during the sampling of Lower Cretaceous sections in Eastern England, especially the difficult sections of the Speeton Clay in the cliff at Speeton. John Callomon, University College, London, is thanked for guidance to Jurassic sections in Southern
England and Hugh G. Owen, British Museum (Natural History), kindly identified the ammonites in the Adda-2 well.

The technicians at the Geological Survey of Denmark and my colleagues of the project group are thanked for pleasant cooperation. The project leader Olaf Michelsen is thanked for his patience during completion of the work.

A special thanks goes to Erik Thomsen (Geological Institute, Aarhus University) for many discussions during the work, to Richard Wilson (Geological Institute, Aarhus University) for his corrections of the English text and to Stefan Piasecki and Finn Surlyk (Geological Survey of Greenland) for their final improvements of the manuscript. 


\section{Literature}

(All references to dinoflagellates mentioned in the text, but not listed below, are to be found in Lentin \& Williams 1985)

Aarhus, N., Verdenius, J. \& Birkelund, T., 1986: Biostratigraphy of a Lower Cretaceous section from Sklinnabanken, Norway, with some comments on the Andøya exposure. Norsk Geologisk Tidsskrift $66,17-43$.

Ainsworth, N. R., Horton, N. F. \& Penney, R. A., 1985: Lower Cretaceous micropalaeontology of the Fastnet Basin, offshore south-west Ireland. Marine and Petroleum Geology 2, 341-349.

Alberti, G., 1961: Zur Kenntnis Mesozoischer und Alttertiärer Dinoflagellaten und Hystrichosphaerideen von Nord- und Mitteldeutschland sowie einigen anderen Europäischen Gebieten. Palaeontographica A 116, 1-58.

Amédro, F., 1980: Ammonites. In: Robaszynski, F. et al.: Synthese Biostratigraphique de l'Aptien au Santonien du Boulonnais a partir de sept groupes paléontologiques: foraminiferes, nannoplankton, dinoflagellés et macrofaunes. Revue Micropaléont. 22, 230258

Bartenstein, H. \& Bettenstaedt, F., 1962: Marine Unterkreide (Boreal und Tethys). In: Arbeitskreis deutscher Mikropaläontologen: Leitfossilien der Mikropaläontologie. Gebrüder Borntraeger, Berlin-Nikolassee, 225-297.

Batten, D. J., 1980: Aptian and Albian palynomorph assemblages from southern England. Proc. IV int. palynol. conf., Lucknow (1976-77) 2, 403-408.

Below, R., 1981a: Dinoflagellaten-Zysten aus dem oberen Hauterive bis unteren Cenoman Süd-West-Marokkos. Palaeontographica B $176,1-145$.

Below, R., 1981b: Dinoflagellaten-Zysten aus den PlatylenticerasSchichten (unteres Mittel-Valendis) der Ziegeleitongrube Schnepper in Suddendorf/Nordwest-Deutschland. Newsl. Stratigr. 10, 115-125.

Below, R., 1982d: Zur Kenntnis der Dinoflagellaten-Zysten-Populationen im Ober-Apt der Tongrube "Otto Gott" in Sarstedt/ Norddeutschland. N. Jb. Geol. Paläont. Abh. 164, 339-363.

Birkelund, T., Clausen, C. K., Hansen, H. N. \& Holm, L., 1983: The Hectoroceras kochi Zone (Ryazanian) in the North Sea Central Graben and remarks on the Late Cimmerian Unconformity. Danm. geol. Unders., Årbog 1982, 53-72.

Birkelund, T., Thusu, B. \& Vigran, J. O., 1978: Jurassic-Cretaceous biostratigraphy of Norway, with comments on the British Rasenia cymodoce Zone. Palaeontology 21, 31-63.

Buch, A., 1969: Dansk Nordsø E-1. Internal report, Danish Geological Survey. 6 pp.

Casey, R., 1961: The stratigraphical palaeontology of the Lower Greensand. Palaeontology, 3, 487-621.

Casey, R., 1973: The ammonite succession at the Jurassic-Cretaceous boundary in eastern England. In: Casey, R. \& Rawson, P. F. (eds.): The Boreal Lower Cretaceous. Geological Journal Special Issue No. 5. Seel House Press, Liverpool, 193-266.

Clarke, R. F. A. \& Verdier, J. P., 1967: An investigation of microplankton assemblages from the Chalk of the Isle of Wight, England. Koninkl. Nederlandse Akad. Wetensch. Verh., Afd. Natuurk., Eerste Reeks, 24 (3), 96 pp.

Cookson, I. C. \& Hughes, N. F., 1964: Microplankton from the Cambridge Greensand (mid-Cretaceous). Palaeontology, 7, 37-59.

Costa, L. I., 1981: Palynostratigraphy, Upper Jurassic to Lower Cretaceous in the wells $2 / 7-1$ and $2 / 7-3$. NPD Paper 30, 17-21.

Davey, R. J., 1969: Non-calcareous microplankton from the Cenomanian of England, northern France and North America. Part I. Bull. Br. Mus. nat. Hist. (Geol.) 17, 105-180.
Davey, R. J., 1970: Non-calcareous microplankton from the Cenomanian of England, northern France and North America. Part II. Bull. Br. Mus. nat. Hist. (Geol.) 18, 335-397.

Davey, R. J., 1974: Dinoflagellate cysts from the Barremian of the Speeton Clay, England. In: Symposium on Stratigraphic Palynology, Birbal Sahni Institute of Palaeobotany, Special Publication 3, 41-75.

Davey, R. J., 1979b: Marine Apto-Albian palynomorphs from Holes 400A and 402A, IPOD Leg 48, northern Bay of Biscay. Initial Reports of the Deep Sea Drilling Project, 48, 547-577.

Davey, R. J., 1979c: The stratigraphic distribution of dinocysts in the Portlandian (latest Jurassic) to Barremian (Early Cretaceous) of Northwest Europe. AASP Contribution Series 5b, 49-81.

Davey, R. J., 1982a: Dinocyst stratigraphy of the latest Jurassic to Early Cretaceous of the Haldager No. 1 borehole, Denmark. Danm. Geol. Unders. Ser. B, 6, 57 pp.

Davey, R. J., 1982b: Die Verbreitung der Palynomorphen im späten Apt und frühen Alb Nordwestdeutschlands. Geol. Jb. A65, 365403.

Davey, R. J. \& Verdier, J. P., 1971: An investigation of microplankton assemblages from the Albian of the Paris Basin. Koninkl Nederlandse Akad. Wetensch. Verh., Afd. Natuurk., Eerste Reeks, 26 (2), 58 pp.

Davey, R. J. \& Verdier, J. P., 1973: An investigation of microplankton assemblages from latest Albian (Vraconian) sediments. Rev Esp. Micropal. 5, 173-212.

Davey, R. J. \& Verdier, J. P., 1974: Dinoflagellate cysts from the Aptian type sections at Gargas and La Bédoule, France. Palaeontology 17, 623-653.

Deflandre, G., 1935: Considérations biologiques sur les microorganismes d'origine planctonique conservés dans les silex de la craie. Bull. Biol. France et Belgique, 69, 213-244.

De Renéville, P. \& Raynaud, J.-F., 1981: Palynologie du stratotype du Barrémien. Bull. Centres Rech. Explor.-Prod. Elf-Aquitaine, 5 (1), 1-29.

Duxbury, S., 1977: A palynostratigraphy of the Berriasian to Barremian of the Speeton Clay of Speeton, England. Palaeontographica B, 160, 17-67

Duxbury, S., 1978: Early Cretaceous dinoflagellate cysts. In: B. Thusu (ed.): Distribution of biostratigraphically diagnostic dinoflagellate cysts and miospores from the Northwest European continental shelf and adjacent areas. Continental Shelf Inst. Publ. 100, 19-29.

Duxbury, S., 1979: Three new genera of dinoflagellate cysts from the Speeton Clay (Early Cretaceous) of Speeton, England. Micropaleontology, 25, 198-205.

Duxbury, S., 1980: Barremian phytoplankton from Speeton, East Yorkshire. Palaeontographica B, 173, 107-146.

Duxbury, S., 1983: A study of dinoflagellate cysts and acritarchs from the Lower Greensand (Aptian to Lower Albian) of the Isle of Wight, southern England. Palaeontographica B, 186, 18-80.

Eisenack, A., 1958: Mikroplankton aus dem norddeutschen Apt nebst einigen Bemerkungen über fossile Dinoflagellaten. N. Jb. Geol. Paläont. Abh. 106, 383-422.

Fisher, M. J. \& Riley, L. A., 1980: The stratigraphic distribution of dinoflagellate cysts at the boreal Jurassic-Cretaceous boundary. Proc. IV int. palynol. conf., Lucknow (1976-77) 2, 313-329.

Foucher, J.-C., 1979: Distribution stratigraphique des kystes de dinoflagellés et des acritarches dans le Crétacé Supérieur du Bassin de Paris et de l'Europe septentrionale. Palaeontographica B, 169, $78-105$. 
Foucher, J.-C., 1980: Dinoflagellés et acritarches. In: Robaszynski, F. et al.: Synthese Biostratigraphique de l'Aptien au Santonien du Boulonnais a partir de sept groupes paléontologiques: foraminiferes, nanoplankton, dinoflagellés et macrofaunes. Revue Micropaléont. 22, 288-296.

Foucher, J.-C., 1981: Kystes de Dinoflagellés du Crétacé Moyen Européen: Proposition d'une Eschelle Biostratigraphique pour le Domaine Nordoccidental. Cretaceous Research 2, 331-338.

Foucher, J.-C., 1983: Distribution des kystes de dinoflagellés dans le Crétacé moyen et Supérieur du Bassin de Paris. Cahiers Micropaléont. 1983 (4) 41 pp.

Foucher, J.-C. \& Taugourdeau, Ph., 1975: Microfossiles de l'AlboCénomanien de Wissant (Pas-de-Calais). Cahiers Micropaléont. 1975 (1) $30 \mathrm{pp}$.

Gocht, H., 1957: Mikroplankton aus dem nordwestdeutschen Neokom (Teil I). Paläont. Z. 31, 163-185.

Gocht, H., 1959: Mikroplankton aus dem nordwestdeutschen Neokom (Teil II). Paläont. Z. 33, 50-89.

Gowers, M. B. \& Sæbøe, A., 1985: On the structural evolution of the Central Trough in the Norwegian and Danish sectors of the North Sea. Marine and Petroleum Geology 2, 298-317.

Gudmundsson, L., 1985: Nedsyring af uorganiske materialer ved hjælp af massenedsyringsmetoden. Palyno-nytt, Newsletter for Scandinavian palynologists 2, 3-6.

Habib, D. \& Drugg, W. S., 1983: Dinoflagellate age of Middle Jurassic-Early Cretaceous sediments in the Blake-Bahama Basin. Initial Reports of the Deep Sea Drilling Project 76, 623-638.

Herngreen, G. F. W., 1978: A preliminary dinoflagellate zonation of Aptian-Cenomanian in the Netherlands. Palinologia, num. extraord. 1, 273-281.

Jensen, T. F. \& Buchardt, B., 1986: Sedimentology and geochemistry of the organic carbon rich Lower Cretaceous Sola Formation (Barremian-Albian), Danish North Sea. Danish Geological Survey, internal report $30,22 \mathrm{pp}$.

Jensen, T. F., Holm, L., Frandsen, N. \& Michelsen, O., 1986 Jurassic - Lower Cretaceous lithostratigraphic nomenclature for the Danish Central Trough. Danm. Geol. Unders. Ser. A, 9, 65 pp.

Kemper, E., 1971: Zur Abgrenzung und Unterteilung des Valanginium ("Valendis"). Newsl. Stratigr. 1, 45-58.

Kemper, E, 1973: The Valanginian and Hauterivian stages in northwest Germany. In: Casey, R. \& Rawson, P. F. (eds.): The Boreal Lower Cretaceous. Geological Journal Special Issue No. 5. Seel House Press, Liverpool, 327-344.

Kemper, E., Rawson, P. F. \& Thieuloy, J.-P., 1981: Ammonites of Tethyan ancestry in the early Lower Cretaceous of north-west Europe. Palaeontology, 24, 34-47.

Lentin, J. K. \& Williams, G. L., 1985: Fossil Dinoflagellates: Index to Genera and Species, 1985 Edition. Can. Tech. Rep. Hydrogr. Ocean Sci. 60, 451 pp.

Millioud, M. E., 1967: Palynological study of the type localities at Valangin and Hauterive. Rev. Palaeobotan. Palynol. 5, 155-167.

Millioud, M. E., 1969: Dinoflagellates and acritarchs from some western European Cretaceous type localities. In: Bronnimann, P. \& Renz, H. H. (eds): Proceedings of the First International Conference on Planktonic Microfossils. Geneva, 1967, E. J. Brill, Leiden, vol. 2, 420-434.
Morgan, R., 1980: Some Early Cretaceous Organic-walled Microplankton from the Great Australian Basin, Australia. Journ. Proc. Roy. Soc. New South Wales, 108, 157-167.

Neale, J. W., 1974: Cretaceous. In: Rayner, D. H. \& Hemingway, J. E. (eds.): The Geology and Mineral Resources of Yorkshire. The Yorkshire Geological Society, 225-243.

Neale, J. W. \& Sarjeant, W. A. S., 1962: Microplankton from the Speeton Clay of Yorkshire. Geol. Mag. 99, 439-458.

Norris, G., 1965: Archeopyle structures in Upper Jurassic dinoflagellates from southern England. NZ. J. Geol. Geophys. 8, 792-806.

Piasecki, S., 1984: Dinoflagellate cyst stratigraphy of the Lower Cretaceous Jydegård Formation, Bornholm, Denmark. Bull. geol. Soc. Denmark 32, 145-161.

Rawson, P., 1971: The Hauterivian (Lower Cretaceous) biostratigraphy of the Speeton Clay of Yorkshire, England. Newsl. Stratigr. 1(4), 61-76.

Rawson, P. F., 1983: The Valanginian to Aptian stages - current definitions and outstanding problems. Zitteliana 10, 493-500.

Rawson, P. F., Curry, D., Dilley, F. C., et al., 1978: A correlation of Cretaceous rocks in the British Isles. Geol. Soc. Lond., Special Report No. 9, 70 pp.

Raynaud, J. F., 1978: Principaux dinoflagellés caractéristiques du Jurassique Superieur d'Europe du Nord. Palinologia, num. extraord. 1, 387-405.

Riding, J. B., 1984: Dinoflagellate cyst range-top biostratigraphy of the uppermost Triassic to lowermost Cretaceous of Northwest Europe. Palynology 8, 195-210.

Robaszynski, F., Amédro, F., Foucher, J. C., Gaspard, D., MagniezJannin, F., Manivit, H. \& Sornay, J.: Synthése biostratigraphique de l'Aptien au Santonien du Boulonnais a partir de sept groupes paléontologiques: foraminiferes, nannoplancton, dinoflagellés et macrofaunes. Rev. Micropaléont. 22, 195-321.

Sarjeant, W. A. S., 1979: Middle and Upper Jurassic dinoflagellate cysts: The world excluding North America. AASP Contribution Series 5B, 133-157.

Srivastava, S. K., 1984: Barremian dinoflagellate cysts from southeastern France. Cahiers Micropaléont. 1984 (2) 90 pp.

Thomsen, E. in press: Lower Cretaceous calcareous nannofossil biostratigraphy of the Danish Central Trough. Danm. Geol. Unders. Ser. A.

Vejbæk, O. V., 1986: Seismic stratigraphy and tectonic evolution of the Lower Cretaceous in the Danish Central Trough. Danm. Geol. Unders. Ser. A, 11, 46 pp.

Verdier, J.-P., 1975: Les cystes de dinoflagellés de la section de Wissant et leur distribution stratigraphique au Crétaće moyen. Rev. Micropaléont. 17, 191-197.

Woollam, R. \& Riding, J. B., 1983: Dinoflagellate cyst zonation of the English Jurassic. Rep. Inst. Geol. Sci. 83/2, 42 pp. 
PLATES 1-17 
PLATE 1

All magnifications $\times 500$.

Muderongia extensiva Duxbury, 1977

Fig. 1. I-1, 10340'.

Fig. 3. I-1, 10340'

Muderongia pariata Duxbury, 1977

Fig. 2. Adda-2, 7756'.

Fig. 4. Adda-2, 7753' $3^{\prime \prime}$.

Fig. 6. I-1, 9490'

Fig. 8. I-1, 9480'.

Muderongia staurota Sarjeant, 1966c

Fig. 5. Adda-2, 7753'3'".

Muderongia simplex subsp. microperforata Davey, 1982a Fig. 7. Adda-1, 7800'.

Muderongia simplex Alberti, 1961

Fig. 9. Adda-1, 8100'.

Fig. 10. I-1, 10290'.

Odontochitina operculata (O. Wetzel, 1933a) Deflandre \& Cookson, 1955

Fig. 11. E-1, 8200'. 
PLATE 1

PLATE 2

All magnifications $\times 500$

Muderongia sp. 1

Fig. 1. I-1, 10530'.

Fig. 2. Adda-1, 7940'.

Fig. 3. I-1, 10290'

Fig. 4. I-1, 10340'.

Phoberocysta tabulata Raynaud, 1978

Fig. 5. Adda-1, 7950'.

Fig. 6. Same specimen as in fig. 5

Fig. 7. I-1, 10670'.

Phoberocysta neocomica (Gocht, 1957) Millioud, 1969

Fig. 9. Adda-1, 7720'.

Fig. 10. I-1, 9495'.

Gochteodinia villosa (Vozzhennikova, 1967) Norris, 1978

Fig. 8. Subspecies indeterminate, I-1, 10570'.

Fig. 11. Subspecies indeterminate, I-1, 10340'.

Fig. 13. Subspecies villosa. Early specimen with very fine processes. M-8, 7800'.

Fig. 14. Subsp. villosa, Adda-1, 7950'

Fig. 15. Subsp. villosa, Adda-1, 9150'.

Fig. 18. Subsp. multifurcata Davey, 1982a, I-1, 10530'

Fig. 19. Subsp. multifurcata Davey, 1982a, I-1, 10890'.

Gochteodinia virgula Davey, 1982a

Fig. 12. I-1, $11300^{\prime}$.

Fig. 16. Adda-1, 9170'

Fig. 17. I-1, 10470'

Batioladinium sp. 1 Davey, 1982a

Fig. 20. Adda-1, 7800'.

Fig. 21. I-1, 10530'

Fig. 22. Adda-1, 7870' 

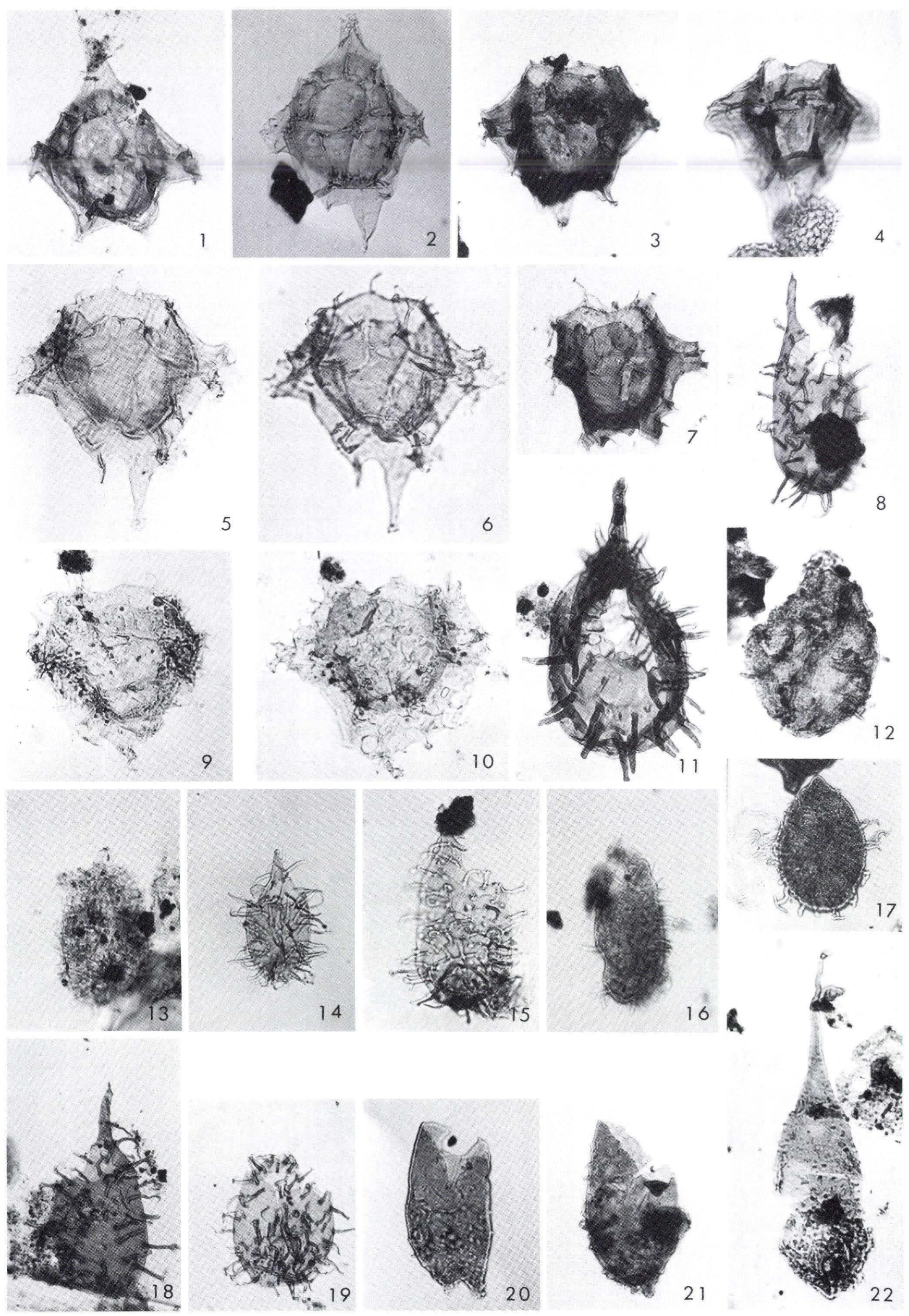

12

6

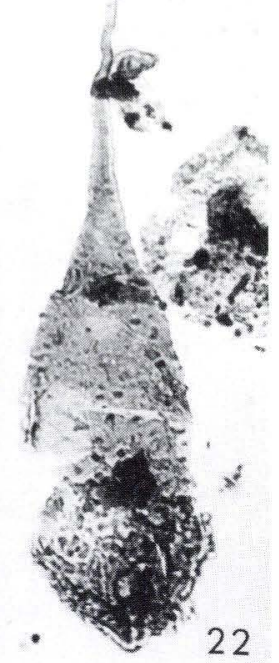


PLATE 3

All magnifications $\times 500$

Batioladinium varigranosum (Duxbury, 1977) Davey, 1982a Fig. 1. Adda-1, 8170'.

Fig. 2. I-1, 10890'.

Batioladinium cf. varigranosum sensu Davey, 1982a

Fig. 3. Adda-1, 8100'.

Fig. 4. Adda-1, 8100'.

Fig. 5. Adda-1, $8250^{\prime}$.

Fig. 6. Adda-1, 7760'.

Batioladinium? pelliferum (Alberti, 1961) Brideaux, 1975

Fig. 7. An almost smooth-walled specimen. Adda-1, 7720'. Fig. 8. I-1, 9510'

Fig. 9. Adda-1, 7800'.

Batioladinium pomum Davey, 1982a

Fig. 10. I-1, 10470'.

Fig. 11. Adda-1, 8650'.

Batioladinium jaegeri (Alberti, 1961) Brideaux, 1975

Fig. 12. I-1, 9420'.

Batioladinium longicornutum (Alberti, 1961) Brideaux, 1975

Fig. 13. E-1, 8200'

Fig. 14. Adda-1, 7600'

Fig. 15. I-1, 9900'

Fig. 16. I-1, 9900'.

Pseudoceratium pelliferum Gocht, 1957

Fig. 17. I-1, 9900'.

Fig. 18. Adda-1, 8460'.

Fig. 19. I-1, 10890'.

Fig. 20. I-1, 10220'.

Pseudoceratium sp. 1

Fig. 21. I-1, 10530'.

Fig. 22. Adda-1, 8800'

Fig. 23. I-1, 10220'.

Fig. 24. Adda-1, 8020' 
PLATE 3
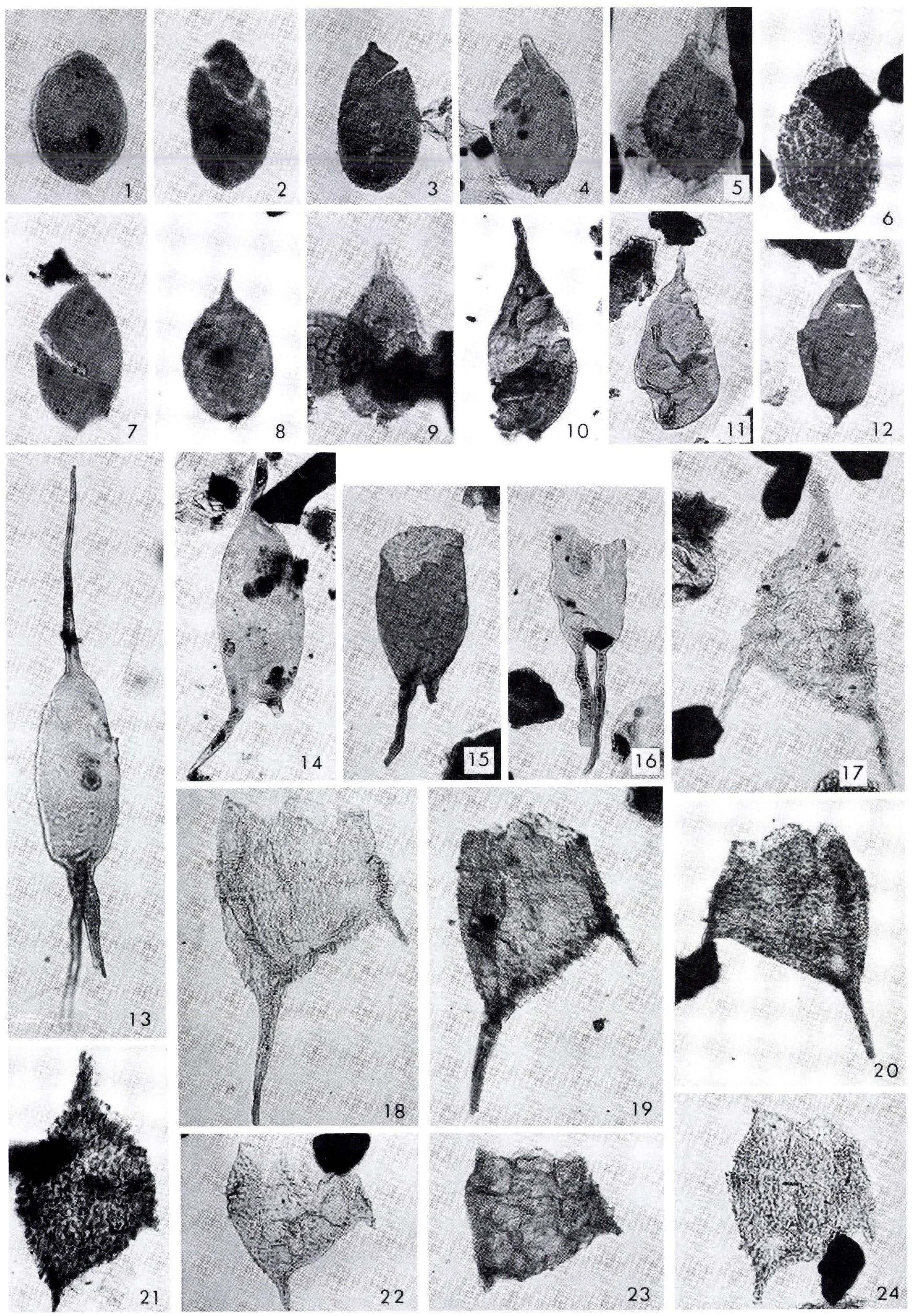

12

22 


\section{PLATE 4}

All magnifications $\times 500$.

Pareodinia sp. 1

Fig. 1. I-1, 9490'

Fig. 2. I-1, 9420'

Fig. 3. I-1, 9420'

Fig. 4. I-1, 9540'

Trichodinium castanea (Deflandre, 1935) Clarke \& Verdier, 1967

Fig. 5. I-1, 10340'

Fig. 6. I-1, 10570'

Fig. 7. Adda-1, $8170^{\prime}$.

Trichodinium speetonense Davey, 1974

Fig. 8. Adda-1, 7710'.

Cerbia tabulata (Davey \& Verdier, 1974) Below, 1981a Fig. 9. Adda-2, 7753'3'".

Fig. 10. I-1, 9780'.

Fig. 11. Adda-2, 7753'3'.

Cyclonephelium hystrix (Eisenack, 1958) Davey, 1978

Fig. 12. A specimen with very stout processes. I-1, 10890'.

Fig. 15. I-1, 9490'

Fig. 16. I-1, 9540'

Aptea securigera Davey \& Verdier 1974

Fig. 13. Adda-1, 7580

Fig. 14. Adda-1, 7580'.

Aptea polymorpha Eisenack, 1958

Fig. 17. I-1, 9490'

Fig. 18. Adda-2, 7753'3'

Fig. 19. I-1, 9780'. 
PLATE 4
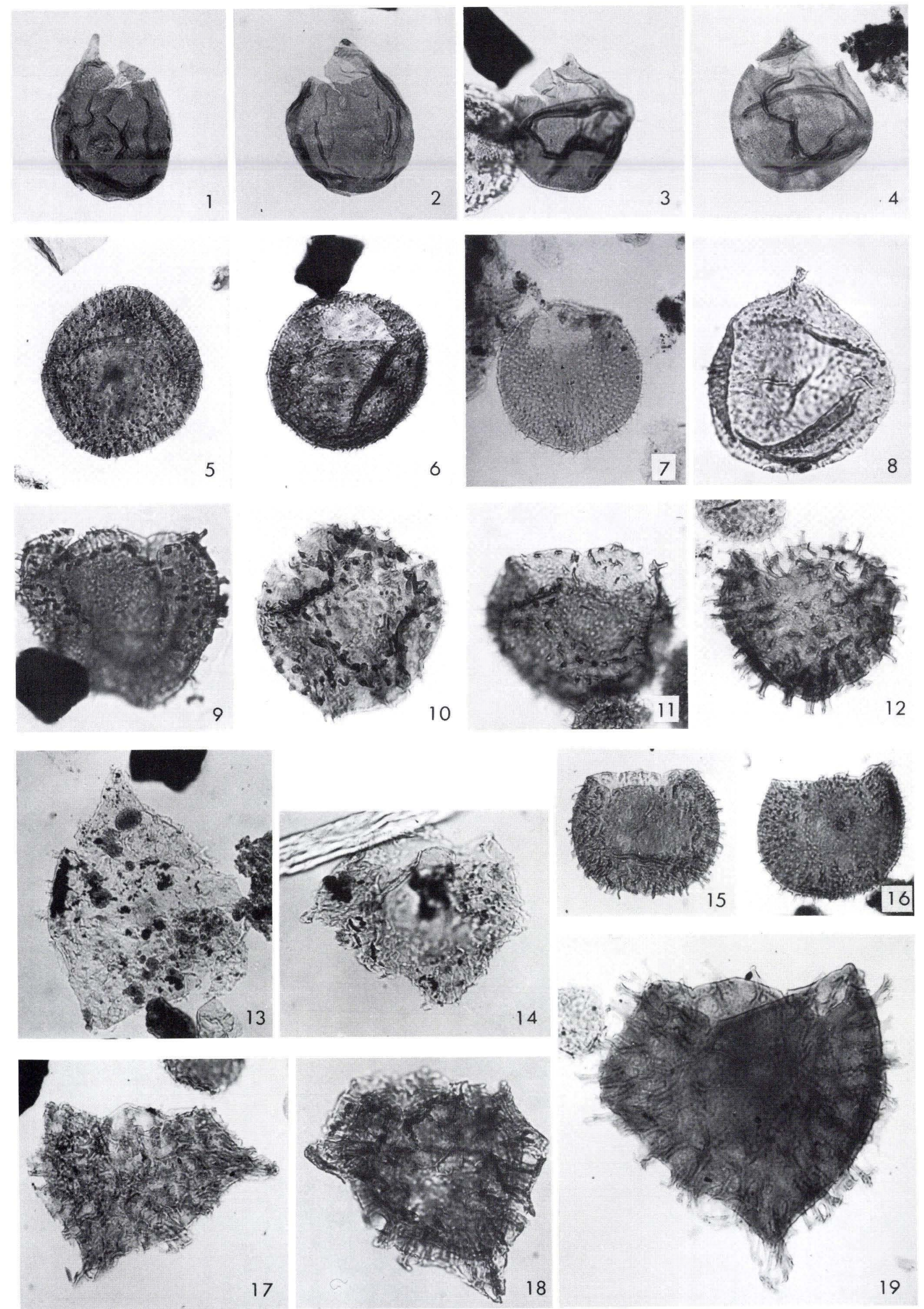


\section{PLATE 5}

All magnifications $\times 500$.

Cepadinium variabile Duxbury, 1983

Fig. 1. A three-layered specimen. Adda-2, 7762'.

Fig. 2. Note archaeopyle margin. Adda-2, $7753^{\prime} 3^{\prime \prime}$.

Subtilisphaera ventriosa (Alberti, 1959b) Jain \& Millepied, 1973

Fig. 3. Adda-1, $7650^{\prime}$.

Fig. 4. I-1, 9490'.

Subtilisphaera perlucida (Alberti, 1959b) Jain \& Millepied, 1973

Fig. 5. Adda-1, 7720'.

Isabelidinium gallium (Davey \& Verdier, 1973) Stover \& Evitt, 1978

Fig. 6. Adda-1, 7540'.

Fig. 7. Adda-1, 7570'.

Ascodinium scabrosum Cookson \& Hughes, 1964

Fig. 8. Adda-1, 7530'.

Fig. 9. Adda-1, 7530'.

Leberidocysta chlamydata (Cookson \& Eisenack, 1962b) Stover \& Evitt, 1978

Fig. 10. I-1, 9370'.

Maduradinium? sp. A Davey, 1982a

Fig. 11. I-1, 10340'

Fig. 12. Adda-1, 7660'

Fig. 13. Adda-1, 7800'

Membranilarnacia polycladiata Cookson \& Eisenack in Eisenack, 1963a

Fig. 14. I-1, 9490'

Fig. 16. I-1, 9540'.

Fig. 17. I-1, 9850'.

Wallodinium anglicum (Cookson \& Hughes, 1964) Lentin \& Williams, 1973

Fig. 15. Adda-2, 7753'3'".

Fig. 18. Adda-1, 7910'

Fig. 22. Adda-1, $7800^{\prime}$

Wallodinium cylindricum (Habib, 1970) Duxbury, 1983

Fig. 19. Adda-1, 8650'

Fig. 20. Adda-1, 7980'

Fig. 21. Adda-1, 8500'.

Senoniasphaera jurassica (Gitmez \& Sarjeant, 1972) Lentin \& Williams, 1976

Fig. 23. Adda-1, 8650'.

Fig. 24. Adda-1, 8170'. 
PLATE 5
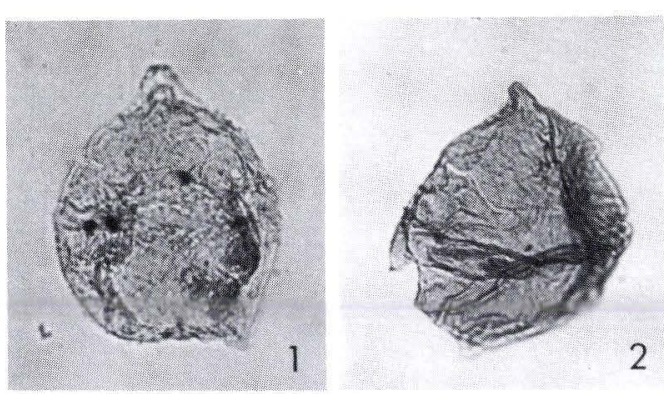

2

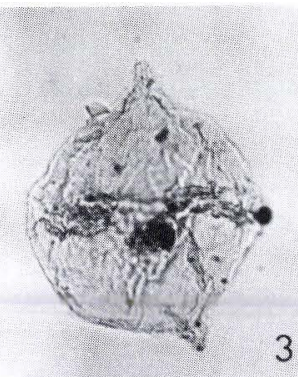

3

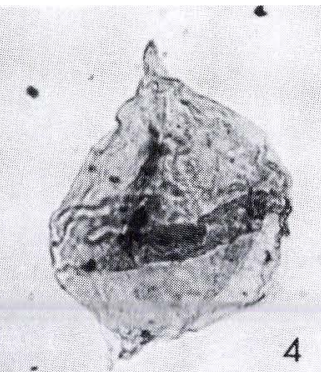

4
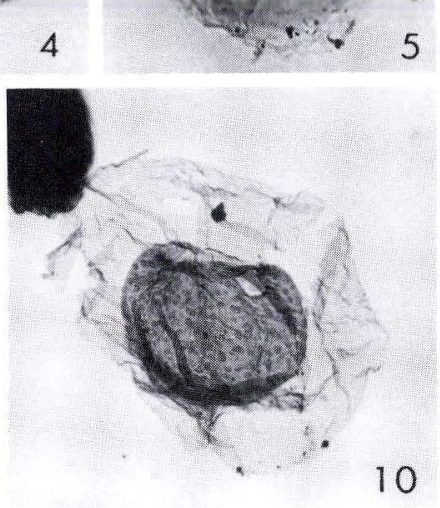
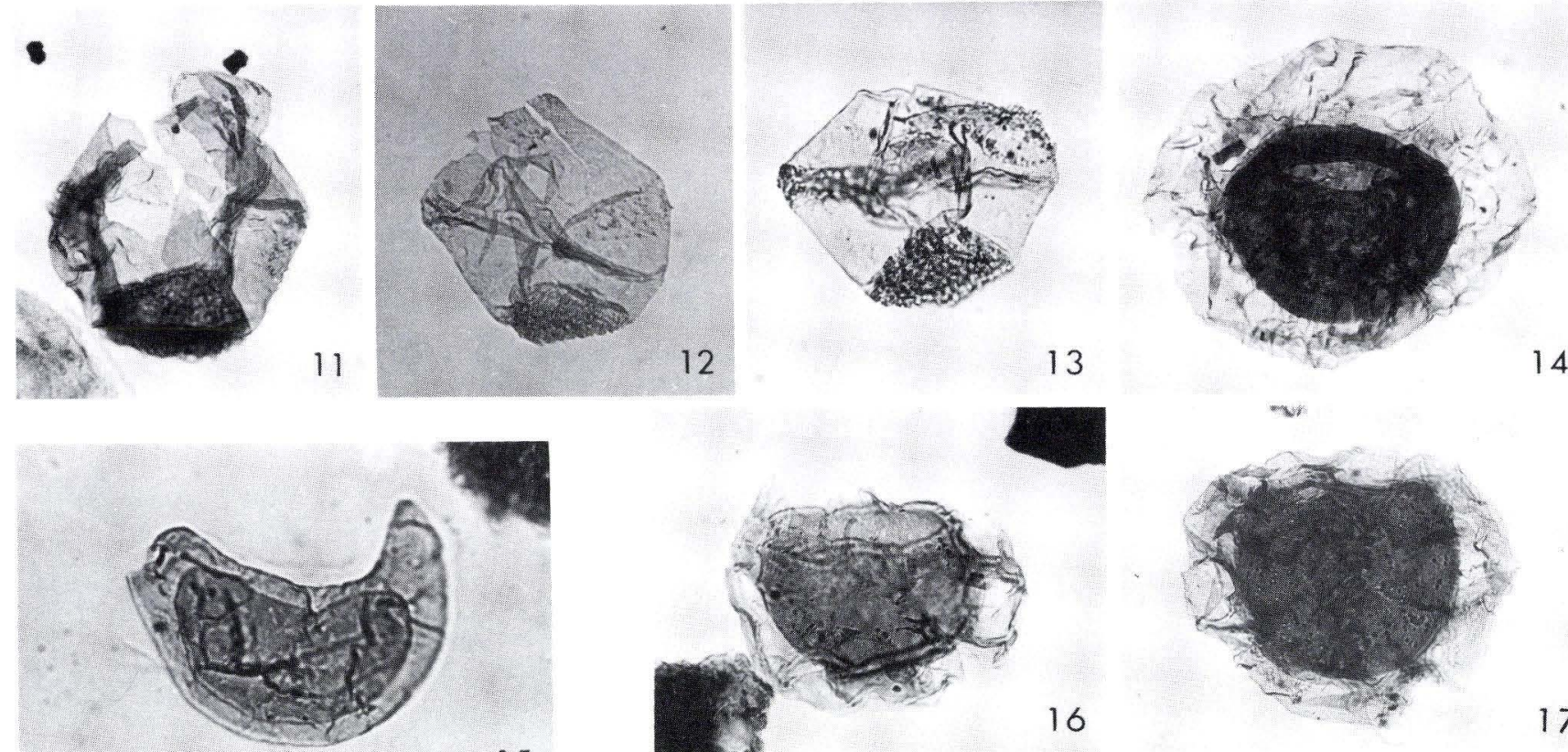

15

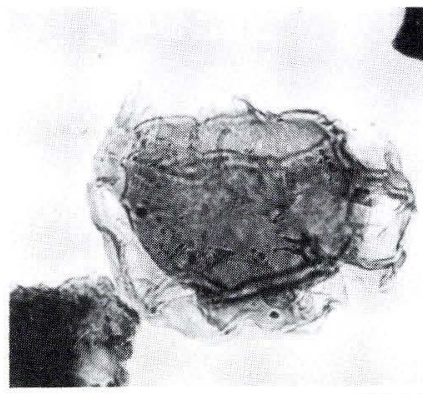

16
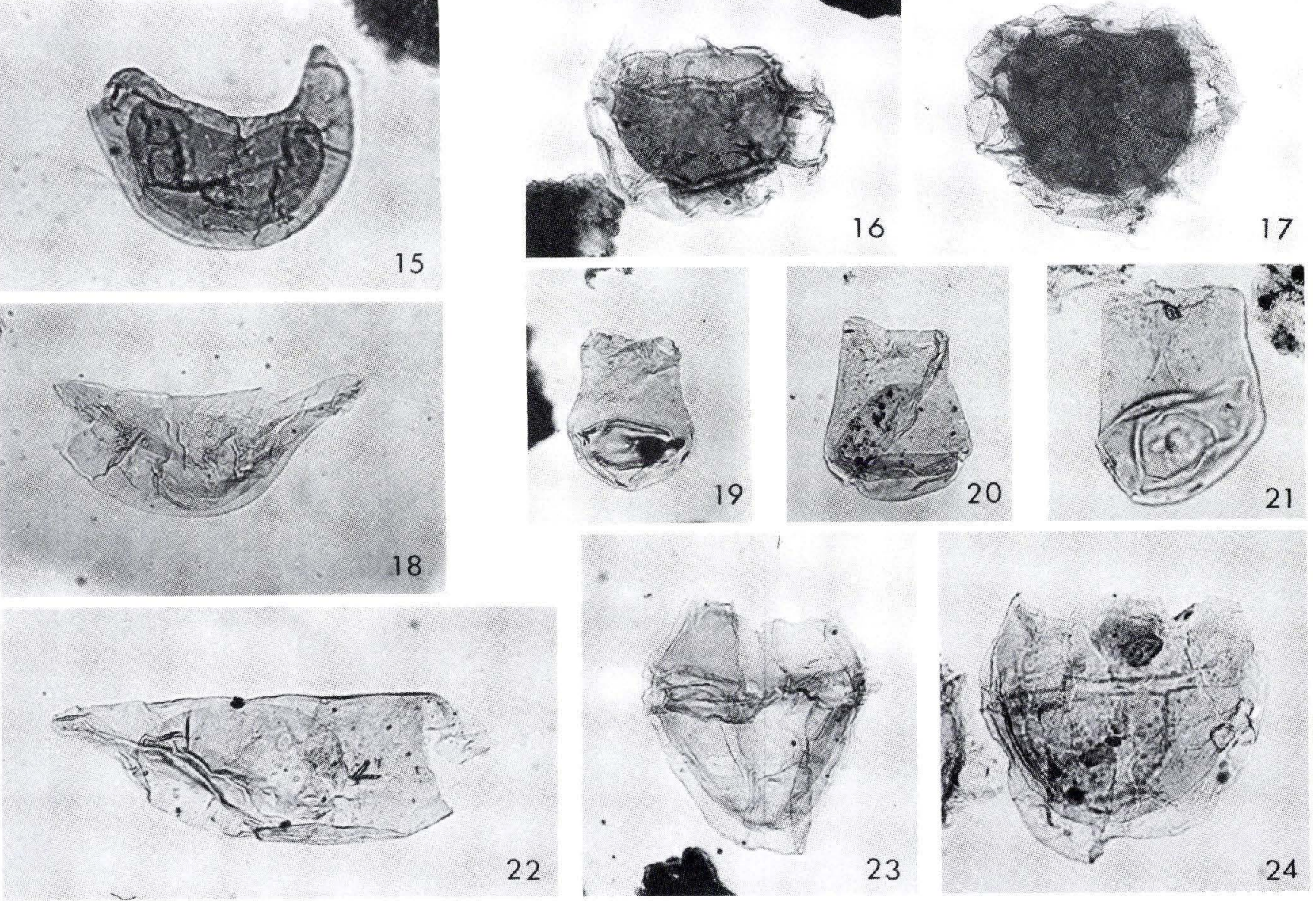
PLATE 6

All magnifications $\times 500$.

Hystrichodinium ramoides Alberti, 1961

Fig. 1. I-1, 9520'.

Hystrichodinium voigtii (Alberti, 1961) Davey, 1974

Fig. 2. I-1, 9540'

Fig. 8. I-1, 10810'

Fig. 9. I-1, 10670'.

Cauca parva (Alberti, 1961) Davey \& Verdier, 1971 Fig. 3. I-1, 10160'.

Fig. 4. I-1, 9370'

Fig. 5. I-1, 9370'.

Canningia compta Davey, 1982a

Fig. 6. Adda-1, 8500'

Fig. 7. I-1, 10570'.

Fromea quadrugata Duxbury, 1980

Fig. 10. I-1, 9820

Fig. 11. Adda-1, 7690'.

Fromea amphora Cookson \& Eisenack, 1958

Fig. 12. Adda-1, 7660'.

Fig. 13. I-1, 9560'.

Tasmanites Newton, 1875

Fig. 14. I-1, 9540'.

Fig. 15. Adda-1, 8600'

Fig. 16. I-1, 11060'

Fig. 17. Adda-1, 8600'

Pterospermella Eisenack, 1972

Fig. 18. I-1, 10730'.

Fig. 19. I-1, 10730'.

Fig. 20. Adda-1, 8500' 
PLATE 6
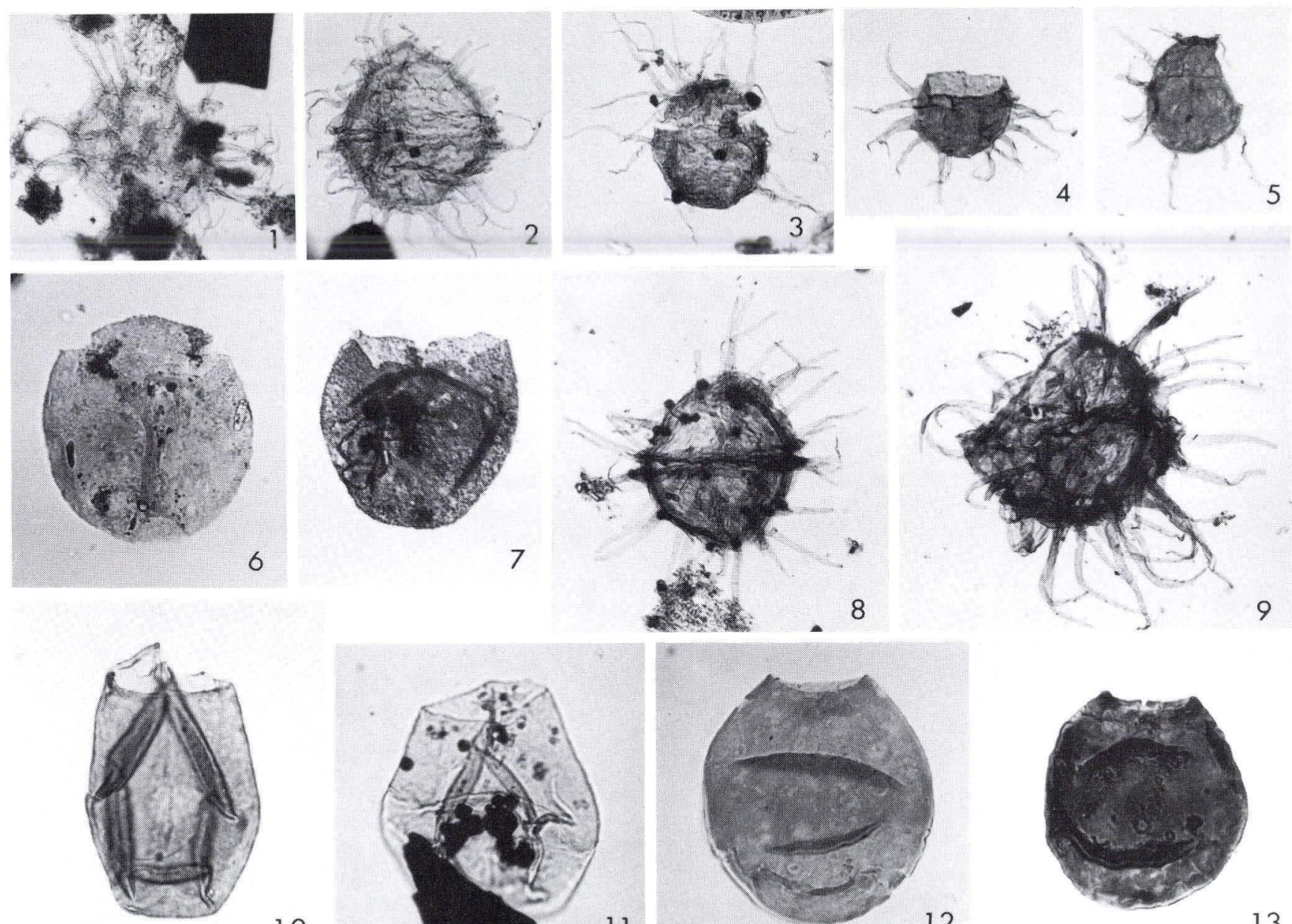

10
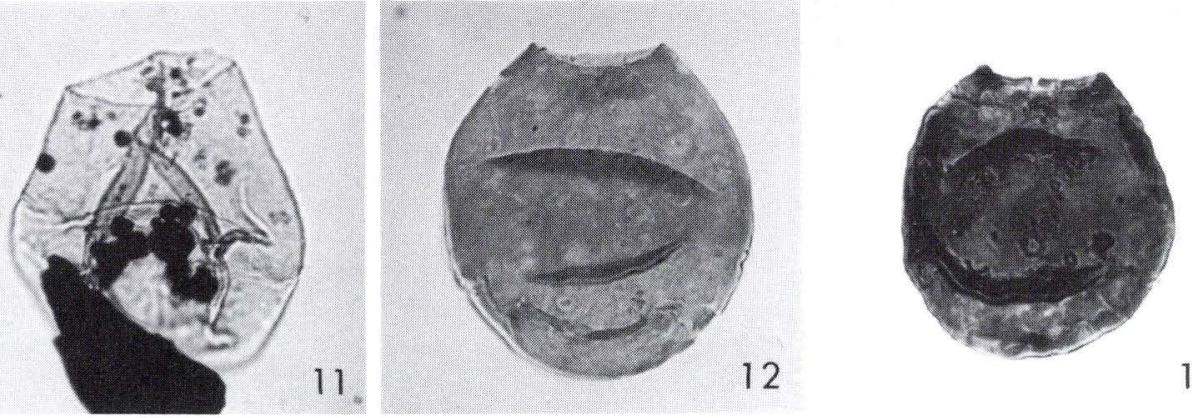

12

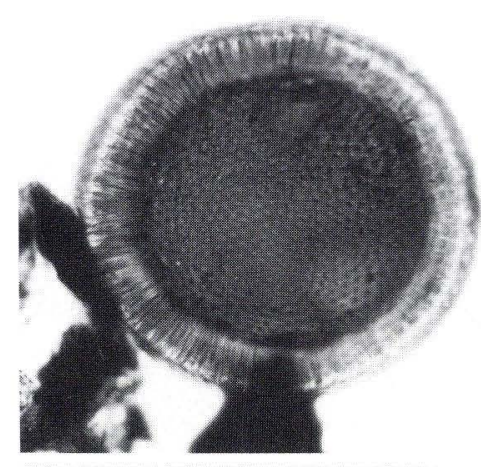

14
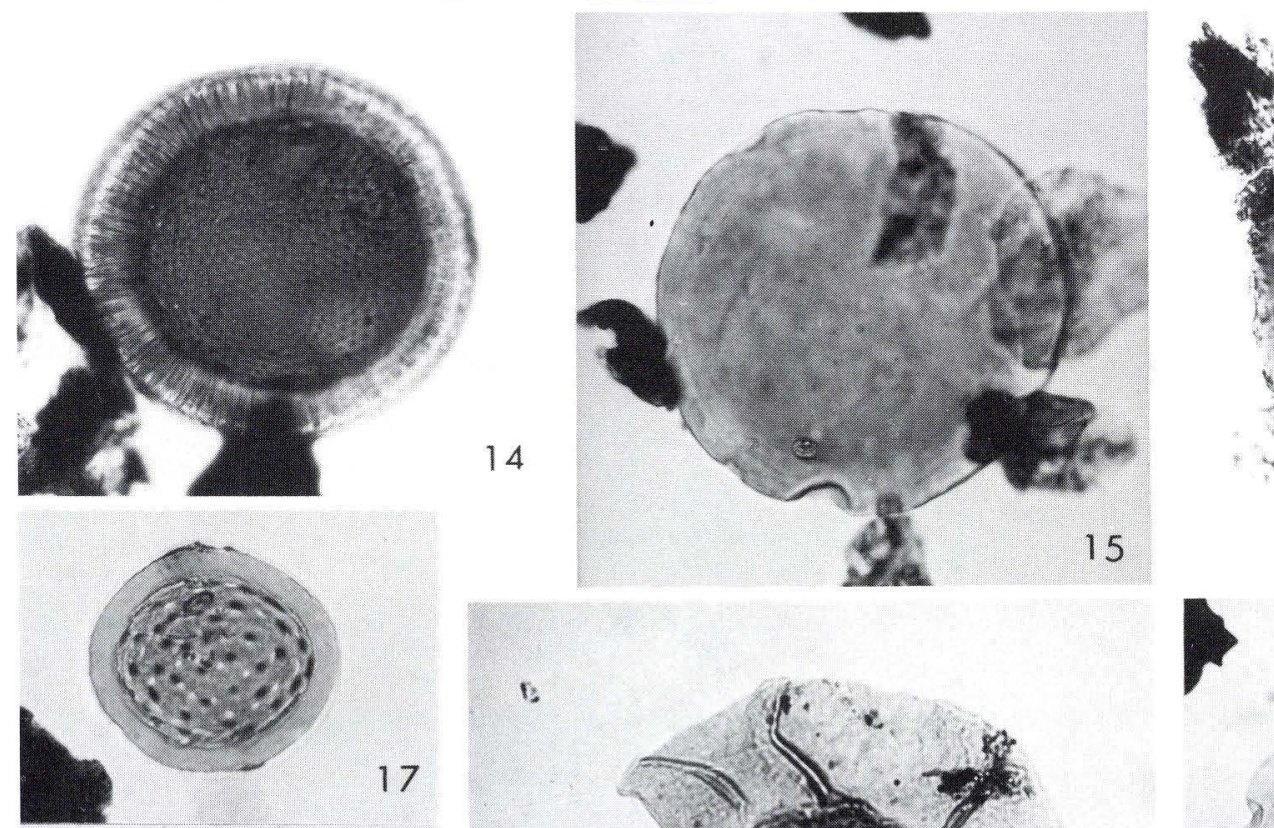

17
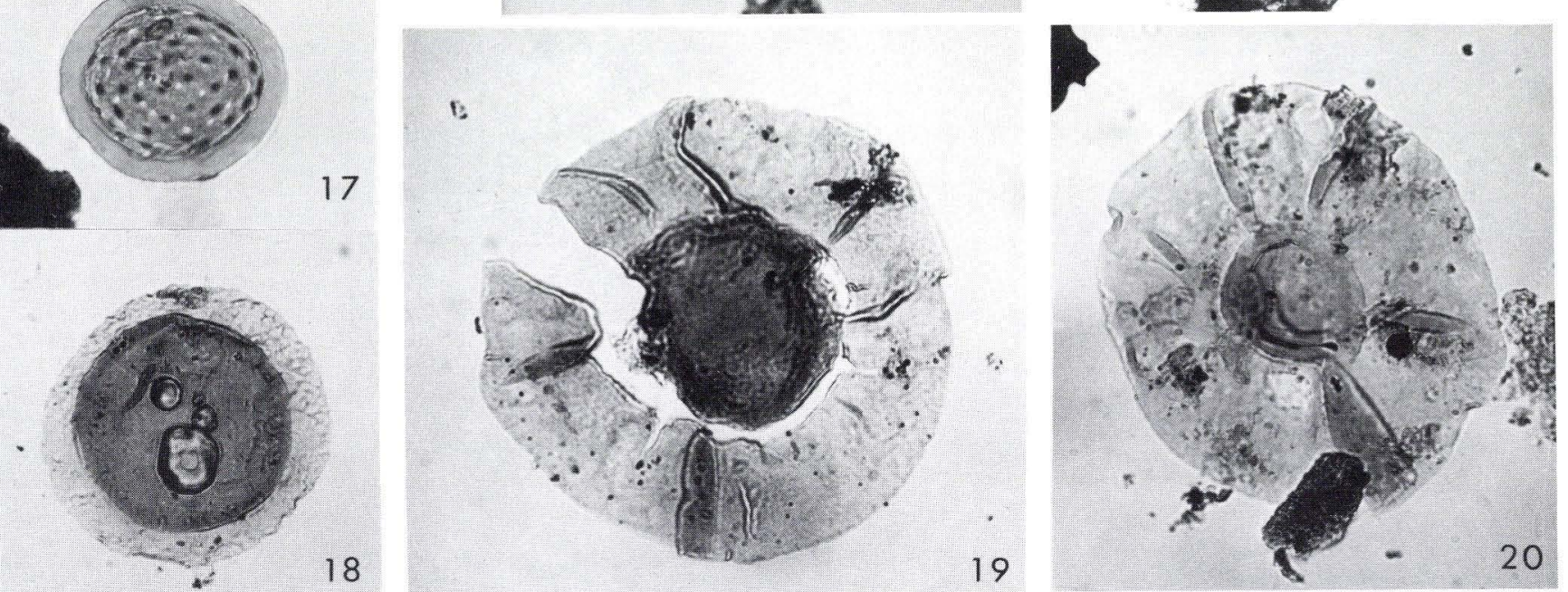
PLATE 7

All magnifications $\times 500$.

Sirmiodiniopsis frisia (Raynaud, 1978) Lentin \& Williams, 1981

Fig. 1. I-1, 10530'.

Fig. 2. Adda- $1,8320^{\prime}$.

Fig. 3. I-1, 10570'.

Fig. 4. Adda-1, 8460'.

Fig. 5. I-1, 10890'.

Sirmiodinium grossii Alberti, 1961

Fig. 6. I-1, 10410'.

Fig. 7. I-1, 10570'

Fig. 8. Adda-1, 7910'.

Fig. 9. Adda-1, 8460'.

Tubotuberella apatela (Cookson \& Eisenack, 1960b) Ioannides et al., 1971

Fig. 10. Adda-1, 7950'.

Fig. 11. I-1, 10750'

Fig. 12. Adda-1, 8250'.

Endoscrinium pharo Duxbury, 1977

Fig. 13. Adda-1, 9000'.

Fig. 18. I-1, 10770'.

Fig. 19. I-1, 10750'.

Endoscrinium granulatum (Raynaud, 1978) Lentin \& Williams, 1981

Fig. 14. E-1, 9720'.

Fig. 17. Adda-1, $8800^{\prime}$.

Endoscrinium campanula (Gocht, 1959) Vozzhennikova, 1967

Fig. 15. Adda-1, 8170'

Fig. 16. I-1, 10570'. 
PLATE 7


14

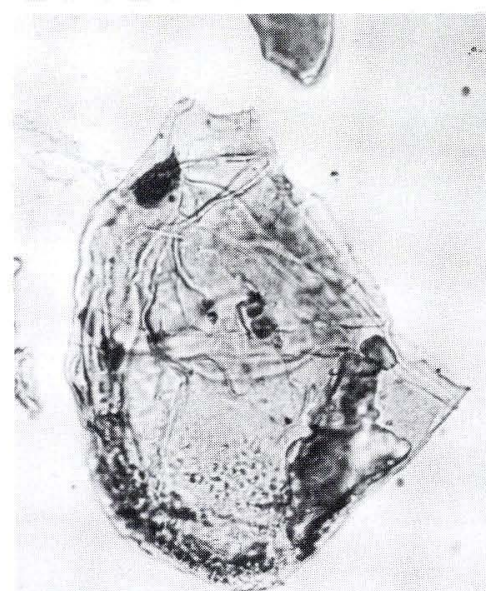

$1:-2$
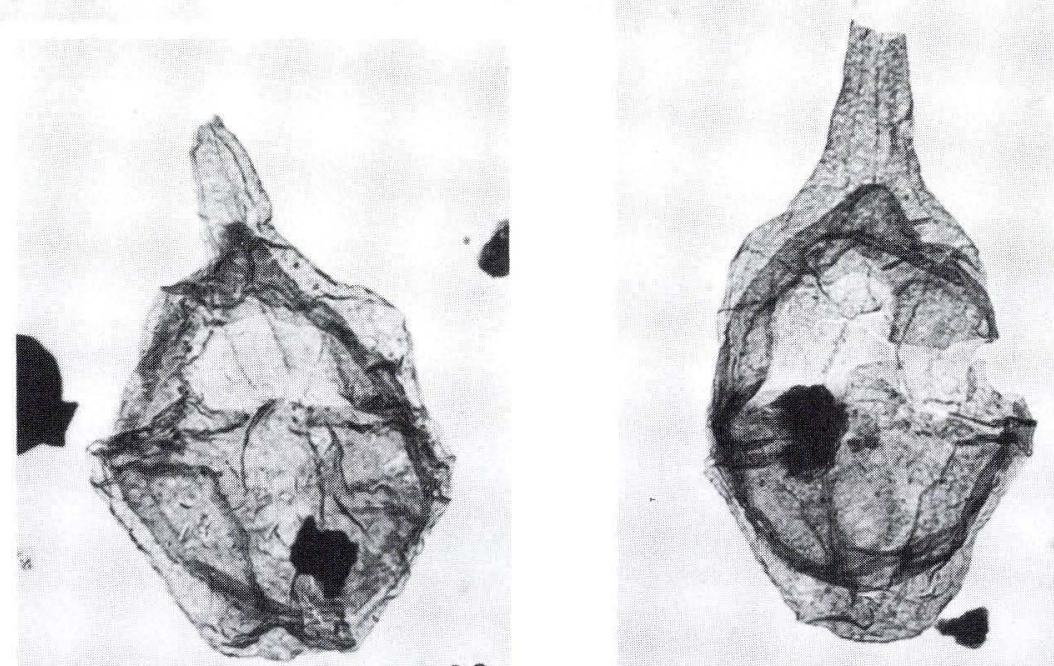

18

16 


\section{PLATE 8}

All magnifications $\times 500$

Carpodinium obliquicostatum Cookson \& Hughes, 1964 Fig. 1. Adda-1, 7530'.

Carpodinium granulatum Cookson \& Eisenack, 1962b

Fig. 2. I-1, 9370'.

Fig. 3. I-1, $9380^{\prime}$

Fig. 4. I-1, 9420'

Fig. 5. I-1, 9480'.

Chytroeisphaeridia cerastes Davey, 1979d

Fig. 6. I-1, 10750'.

Fig. 7. I-1, 10470'.

Lagenorhytis delicatula (Duxbury, 1977) Duxbury, 1979b Fig. 8. Adda-1, 7940'

Fig. 9. I-1, 10710'

Fig. 10. Adda-1, 7910'.

Fig. 11. A small specimen, morphologically transitional to Chytroeisphaeridia cerastes. Adda-1, 7950'.

Ellipsodinium reticulatum Duxbury, 1980

Fig. 12. Adda-1, 7660'.

Fig. 13. Adda-2, 7762'.

Leptodinium cancellatum Brideaux \& McIntyre, 1975

Fig. 14. I-1, 9400'.

Fig. 15. I-1, 9420'.

Cassiculosphaeridia magna Davey, 1974

Fig. 16. I-1, 10890'

Fig. 22. I-1, 10220'.

Fig. 23. I-1, 9539'.

Cassiculosphaeridia reticulata Davey, 1969a

Fig. 17. I-1, 9340'.

Fig. 18. I-1, 9380'.

Fig. 19. Adda-1, 7670'.

Ellipsoidictyum imperfectum (Brideaux \& McIntyre, 1975) Lentin \& Williams, 1977b

Fig. 20. I-1, 9420'.

Fig. 21. I-1, 9420'.

Fig. 24. I-1, 9380'. 
PLATE 8
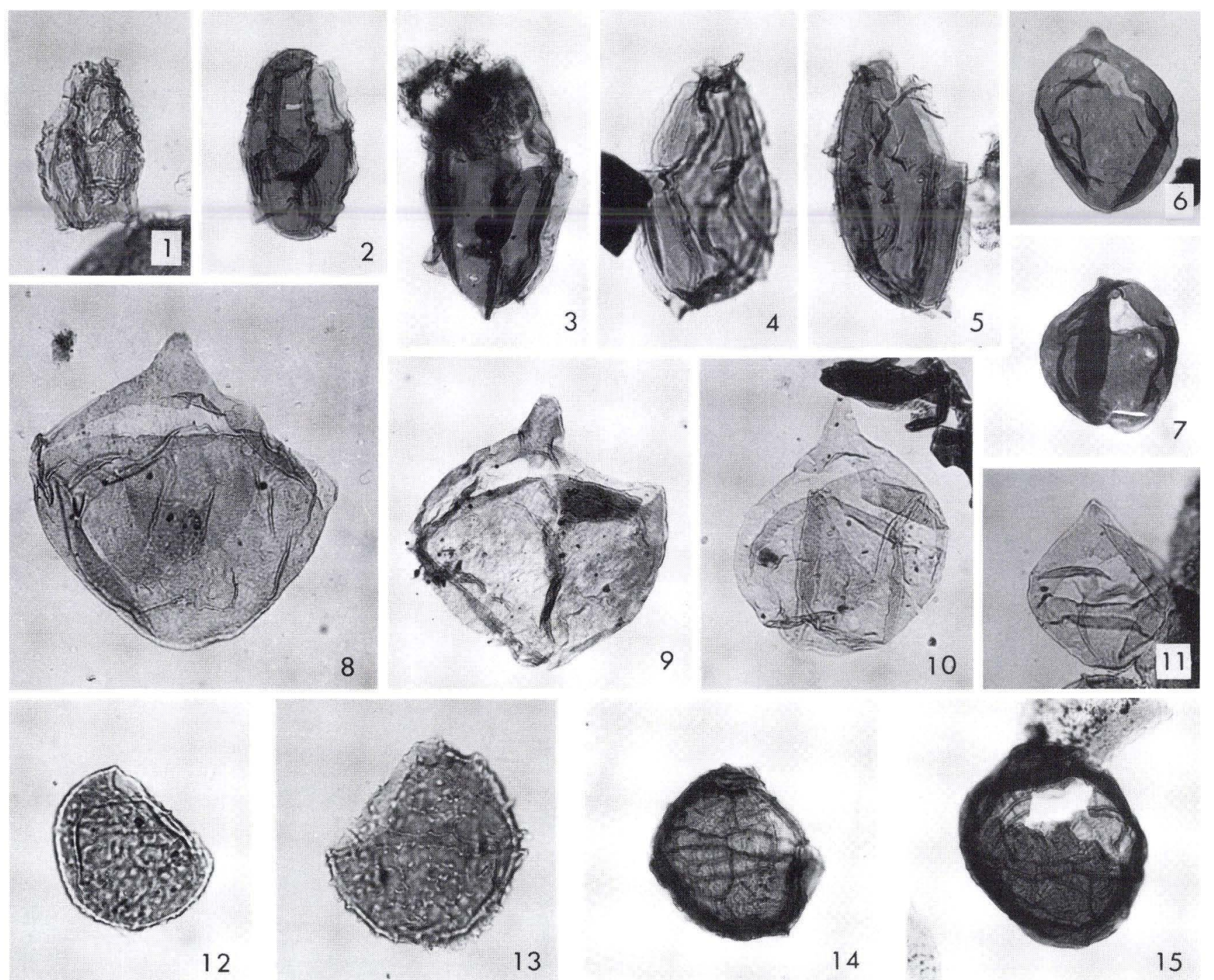

12

13
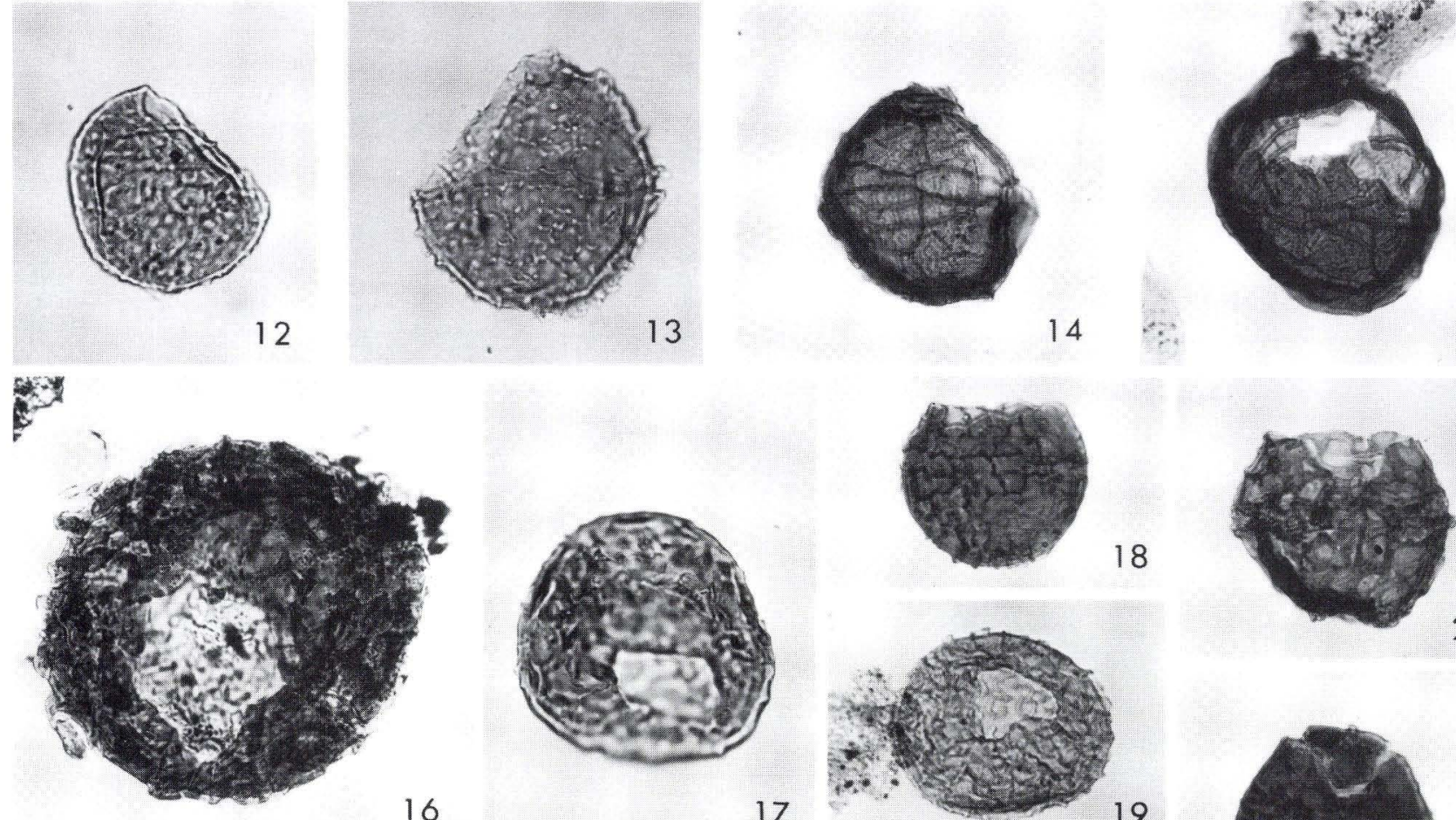

17
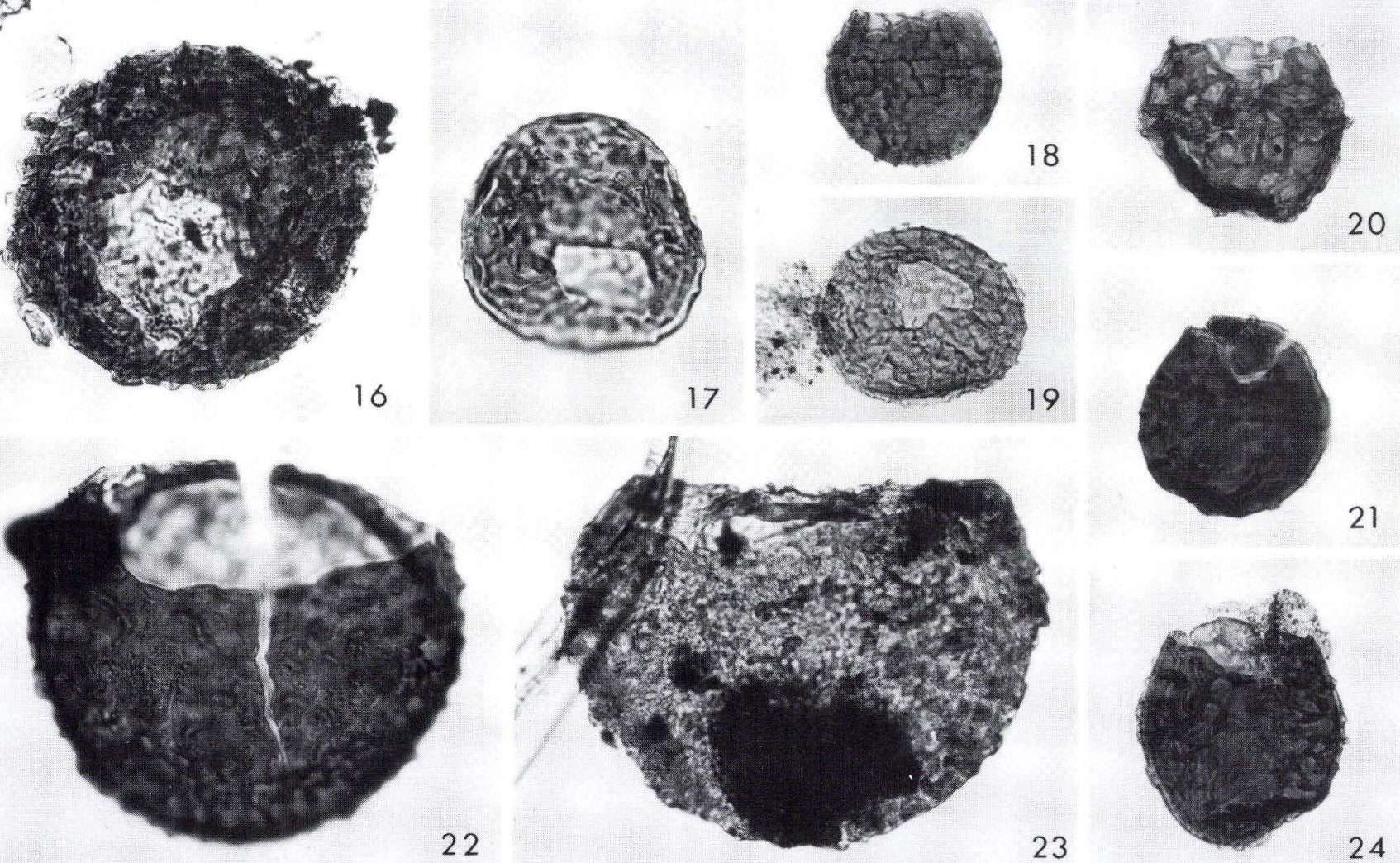
PLATE 9

All magnifications $\times 500$

Diacanthum tenuiceras (Eisenack, 1958) Stover \& Evitt, 1978 Fig. 1. Apical view. I-1, 9360'.

Exiguisphaera phragma Duxbury, 1979a

Fig. 2. Adda-1, 8170'.

Fig. 3. Adda-1, 8250'.

Fig. 4. Adda-1, 9150'.

Exiguisphaera plectilis Duxbury, 1980

Fig. 5. Adda-1, 7610'.

Fig. 6. Adda-1, 7640'.

Aldorfia spongiosa (McIntyre \& Brideaux, 1980) Davey, 1982a

Fig. 7. M-8, 7300'

Apteodinium grande Cookson \& Hughes, 1964

Fig. 8. Adda-1, 7540'.

Fig. 9. Adda-1, 7530'.

Occisucysta evittii (Dodekova, 1969) Gitmez, 1970

Fig. 10. Adda-1, 8430'.

Fig. 11. Adda-1, 8500'.

Fig. 12. Adda-1, 8400'

Fig. 13. Adda-1, $8400^{\prime}$.

Occisucysta tentoria Duxbury, 1977

Fig. 14. I-1, 9490'

Fig. 15. Adda-1, $8650^{\prime}$

Fig. 16. Adda-1, 7940'

Fig. 17. Adda-1, 7940'.

Isthmocystis distincta Duxbury, 1979a

Fig. 18. M-8, 7490'.

Fig. 19. I-1, 10290'

Fig. 20. Adda-1, $7850^{\prime}$. 
PLATE 9

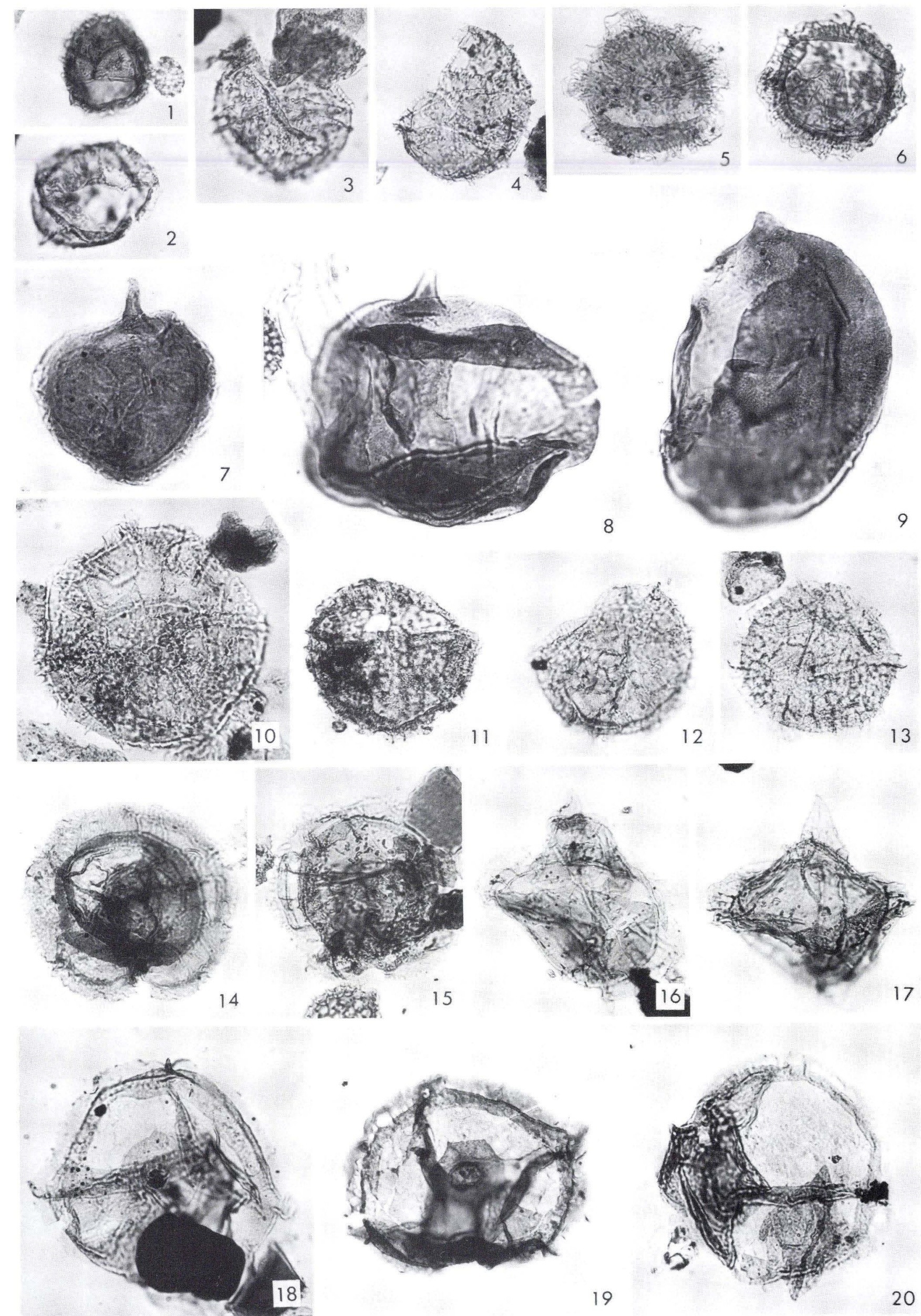


PLATE 10

All magnifications $\times 500$

Gonyaulacysta exanguia Duxbury, 1977

Fig. 1. Adda-1, 8500'

Gonyaulacysta helicoidea (Eisenack \& Cookson, 1960) Sarjeant, $1966 \mathrm{~b}$

Fig. 2. Adda-1, 7950'

Fig. 3. Adda-1, 7800'

Gonyaulacysta? fastigiata Duxbury, 1977

Fig. 4. Adda-1, 8170'.

Fig. 5. I-1, 10410'.

Cribroperidinium sp. A davey, 1982a

Fig. 6. M-8, 7800'.

Gonyaulacysta sp. A Davey, 1982a

Fig. 7. Adda-1, 8550'

Gonyaulacysta perforobtusa Duxbury, 1977

Fig. 8. I-1, 9900'

Gonyaulacysta ordocava Duxbury, 1977

Fig. 9. I-1, 9960'

Rhynchodiniopsis aptiana Deflandre, 1935

Fig. 10. Adda-1, 7650'

Gonyaulacysta cladophora sensu Duxbury, 1977

Fig. 11, I-1, 10570'.

Cribroperidinium? cornutum Davey, 1974

Fig. 12. I-1, 9600'

Fig. 15. Adda-1, 7650'.

Fig. 16. Adda-1, 7710'.

Cribroperidinium? gigas (Raynaud, 1978) Helenes, 1984 Fig. 13. Adda-1, 9150'.

Cribroperidinium sepimentum Neale \& Sarjeant, 1962

Fig. 14. I-1, 10160'. 

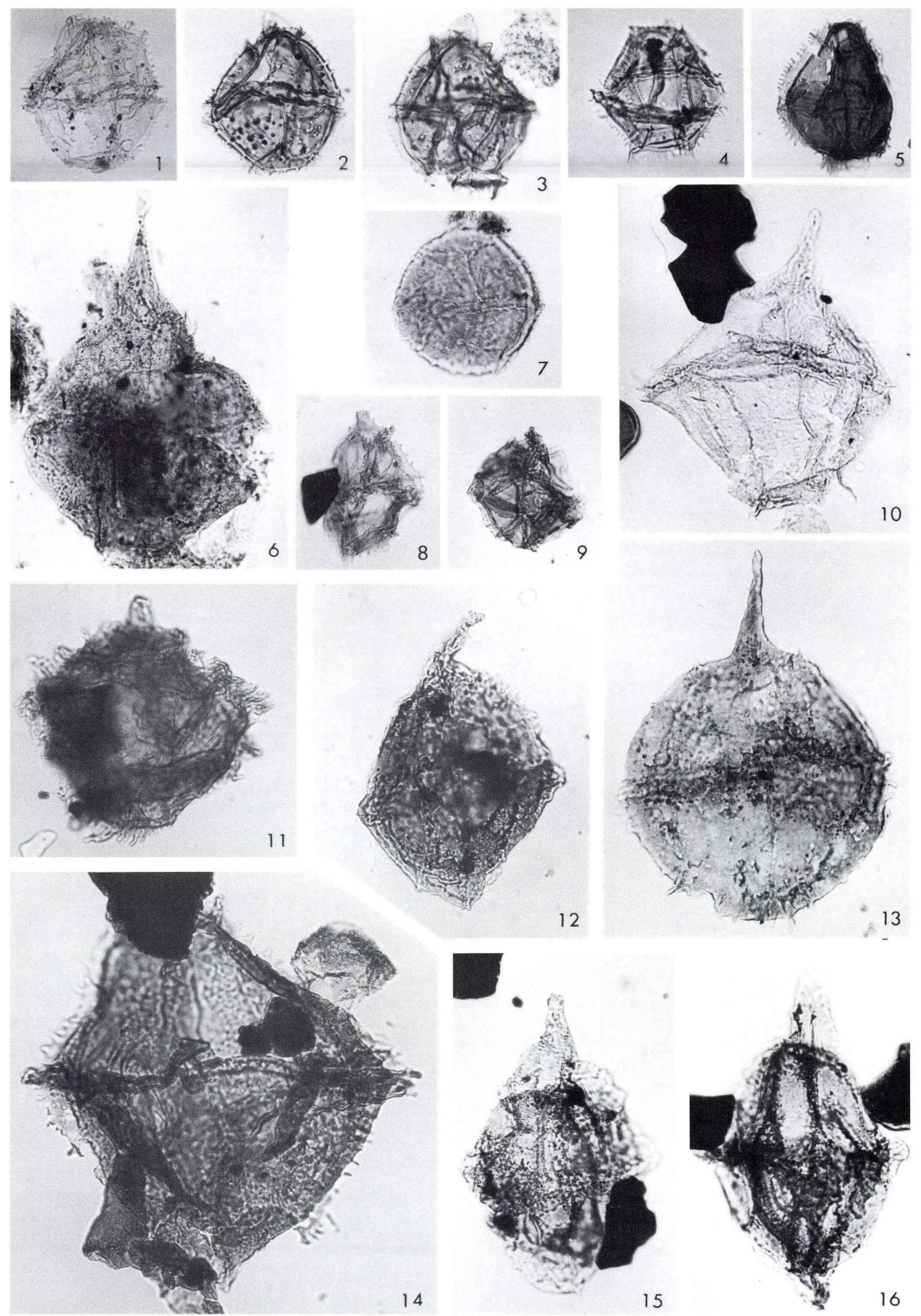
PLATE 11

All magnifications $\times 500$

Gonyaulacysta kostromiensis (Vozzhennikova, 1967) Sarjeant, 1969

Fig. 1. Adda-1, $7760^{\prime}$.

Fig. 2. I-1, 9900'.

Fig. 3. I-1, 10020'

Fig. 4. I-1, 10730'

Spiniferites? dentatus (Gocht, 1959) Lentin \& Williams, 1973 Fig. 5. A specimen showing affinity to Spiniferites multibrevis. Adda-1, 7910'.

Fig. 6. I-1, 10850'

Fig. 9. I-1, 10810'

Fig. 10. Adda-1, 7720'.

Gonyaulacysta cassidata (Eisenack \& Cookson, 1960) Sarjeant, $1966 \mathrm{~b}$

Fig. 7. Adda-1, 7530'.

Spiniferites speetonensis Duxbury, 1980

Fig. 8. Adda-1, 7700'.

Pterodinium cf. aliferum Eisenack, 1958

Fig. 11. Adda-2, 7753'3'".

Pterodinium aliferum Eisenack, 1958

Fig. 16. Adda-2, 7753'3'".

Trabeculodinium quinquetrum Duxbury, 1980

Fig. 12. I-1, 9780'.

Fig. 17. I-1, $9820^{\prime}$.

Nematosphaeropsis scala Duxbury, 1977

Fig. 13. I-1, 9960'

Fig. 14. I-1, 10090'.

Spiniferites ramosus subsp. primaevus Duxbury, 1977

Fig. 15. I-1, 10410'.

Nematosphaeropsis sp. 1

Fig. 18. I-1, 9850'.

Cannosphaeropsis thula Davey, 1982a

Fig. 19. Adda-1, 8700'.

Fig. 20. I-1, 10970'

Fig. 25. Adda-1, 9150'.

Diphasiosphaera stolidota Duxbury, 1980

Fig. 21. Adda-1, 7730'.

Fig. 22. Adda-1, $7760^{\prime}$.

Fig. 23. Adda-1, $7690^{\prime}$

Fig. 24. E-1, 8191'6".

Achomosphaera? neptunii (Eisenack, 1958) Davey \& Verdier, $1966 \mathrm{a}$

Fig. 26. Adda-1, 7690'.

Fig. 27. I-1, 10890'.

Fig. 28. Adda-1, 7640'.

Fig. 29. I-1, 9540'. 

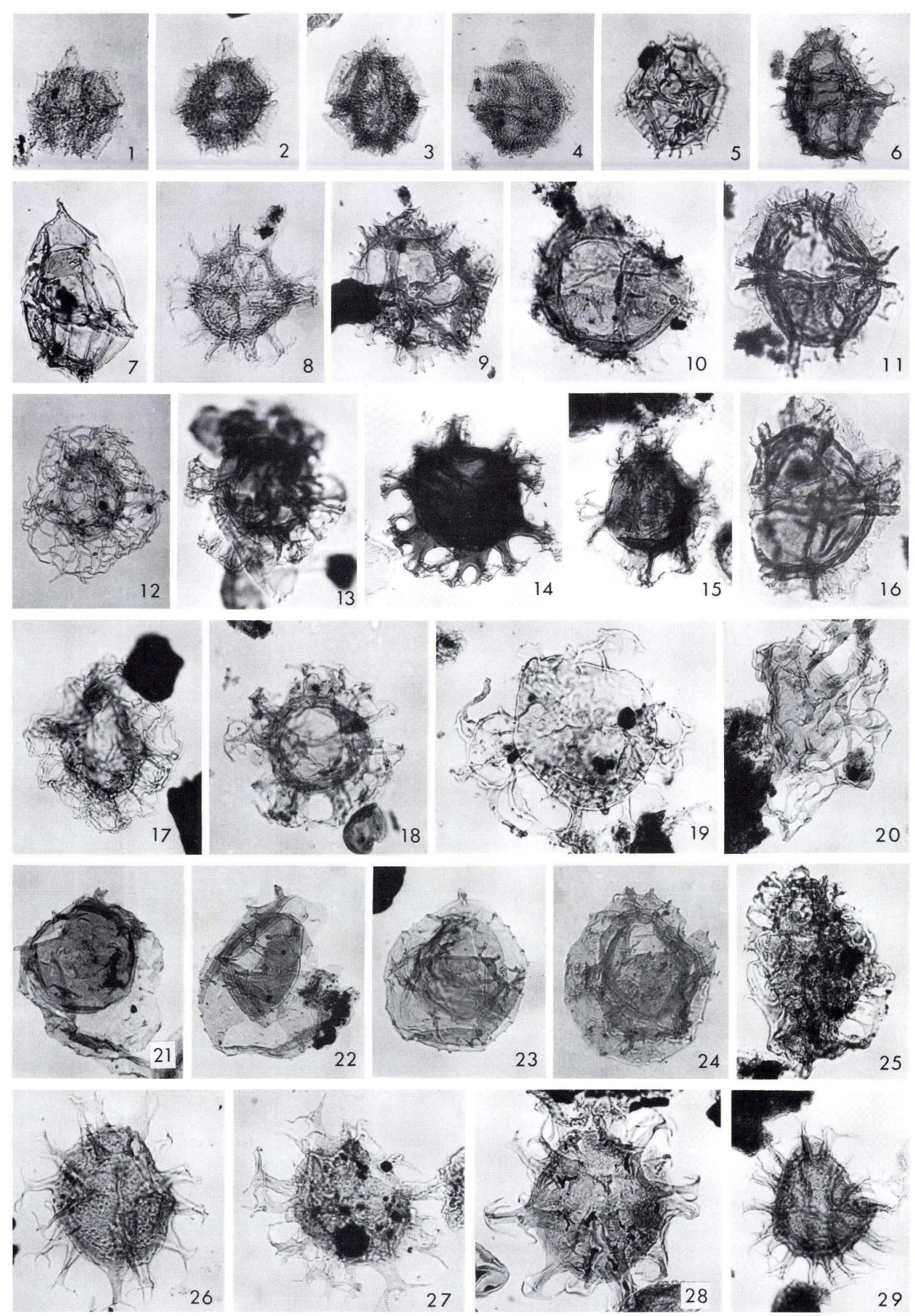
PLATE 12

All magnifications $\times 500$

Mendicodinium groenlandicum (Pocock \& Sarjeant, 1972) Davey, 1979c

Fig. 1. Adda-1, 8250'.

Ctenidodinium elegantulum Millioud, 1969

Fig. 2. E-1, 9720'.

Fig. 3. E-1, $9720^{\prime}$

Fig. 4. I-1, 10530'

Ctenidodinium panneum (Norris, 1965) Lentin \& Williams, 1973

Fig. 5. I-1, 10410'

Fig. 11. Adda-1, 8250'.

Heslertonia pellucida Gitmez, 1970

Fig. 6. I-1, 10850'.

Fig. 7. I-1, 10020'

Fig. 8. I-1, 10020'

Valensiella ovula (Deflandre, 1947c) Eisenack, 1963a

Fig. 9. Adda-1, 8550'.

Fig. 10. Adda-1, $8600^{\prime}$.

Heslertonia heslertonensis (Neale \& Sarjeant, 1962) Sarjeant, $1966 \mathrm{~b}$

Fig. 12. Adda-1, 7650'

Fig. 13. Adda-1, 7670'.

Fig. 14. Adda-1, 7850'.

Fig. 15. I-1, 10850'.

Avellodinium falsificum Duxbury, 1977

Fig. 16. Adda-1, 7690'.

Taleisphaera hydra Duxbury, 1979a

Fig. 17. I-1, 9850'.

Fig. 22. I-1, 9850'.

Callaiosphaeridium asymmetricum (Deflandre \& Courteville, 1939) Davey \& Williams, 1966b

Fig. 18. I-1, 9490'.

Fig. 19. I-1, 9490'.

Callaiosphaeridium trycherium Duxbury, 1980

Fig. 20. Adda-2, 7753' $3^{\prime \prime}$.

Fig. 21. Adda-2, 7753'3'".

Stephodinium spinulosum Duxbury, 1983

Fig. 23. Adda-2, 7753'3'

Stephodinium coronatum Deflandre, 1936a

Fig. 24. Adda-1, 7620'

Fig. 25. I-1, 9780'

Fig. 26. I-1, $9400^{\prime}$.

Chlamydophorella trabeculosa (Gocht, 1959) Davey, 1978 Fig. 27. Adda-1, 7640'.

Fig. 28. M-8, 7490'.

Fig. 29. Adda-1, 7710'.

Chlamydophorella membranoidea Vozzhennikova, 1967 Fig. 30. Adda-1, 7980'.

Fig. 31. Adda-1, 7950'.

Chlamydophorella nyei Cookson \& Eisenack, 1958 Fig. 32. I-1, 10570'. 
PLATE 12
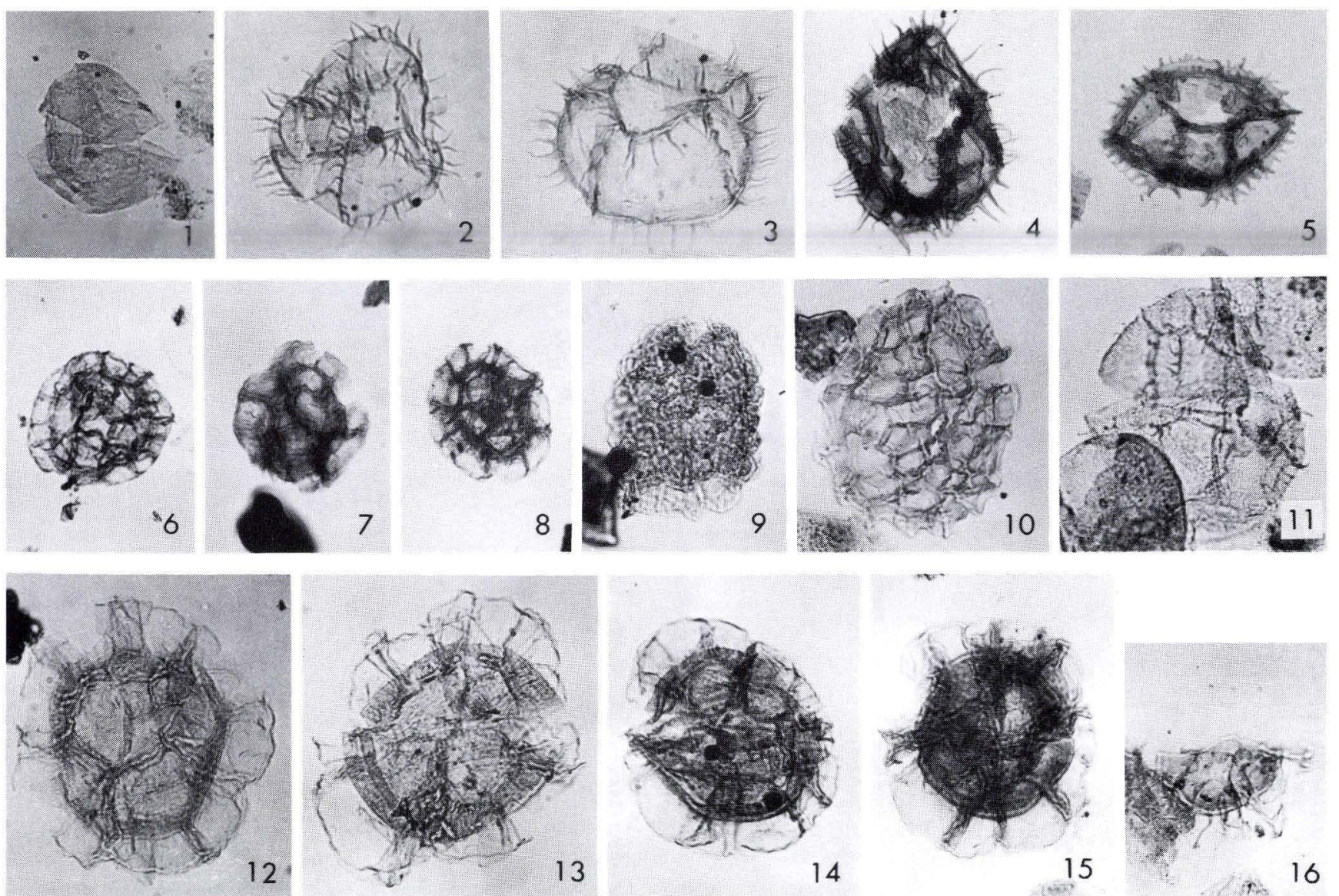

12

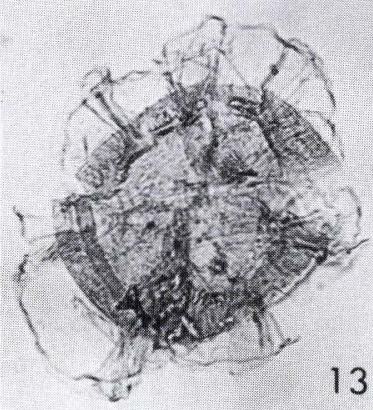

13
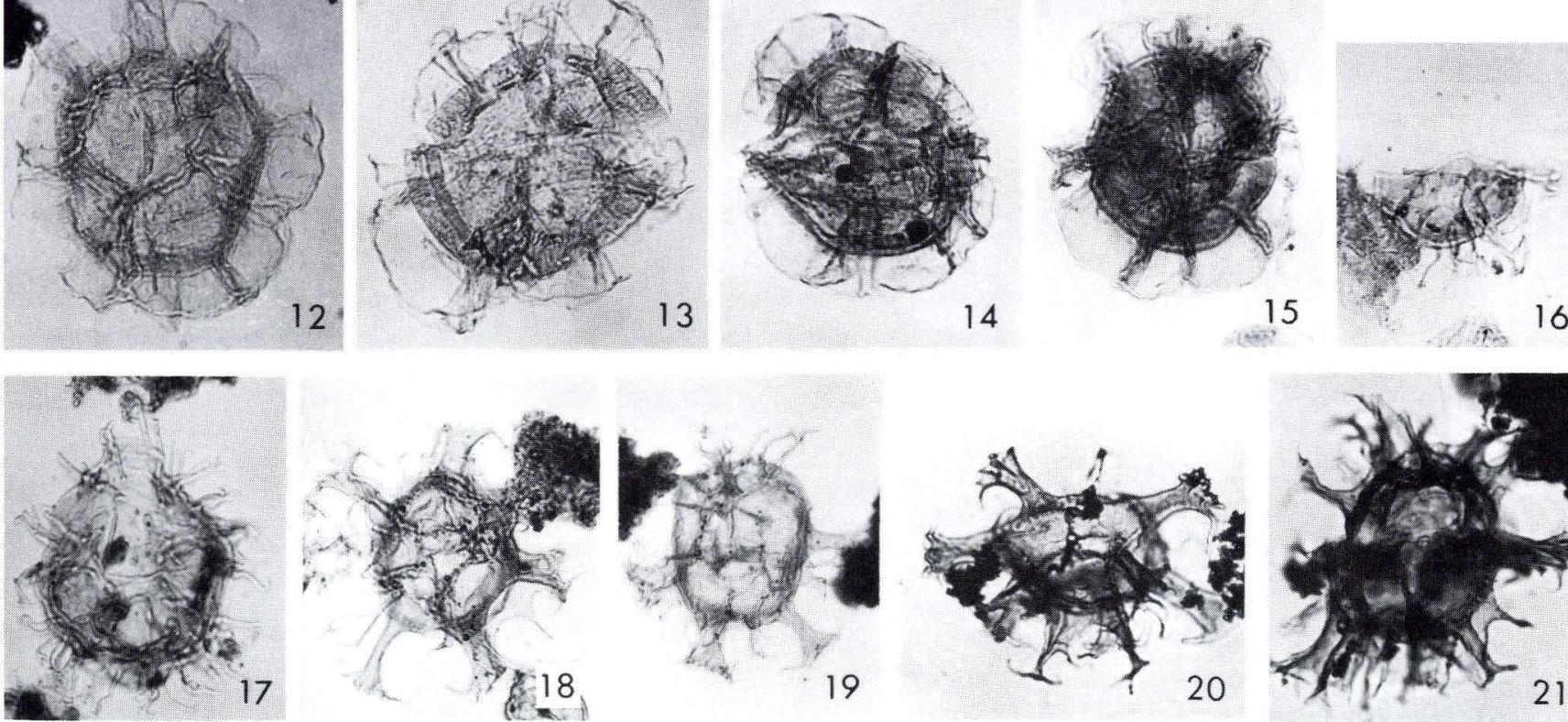

15
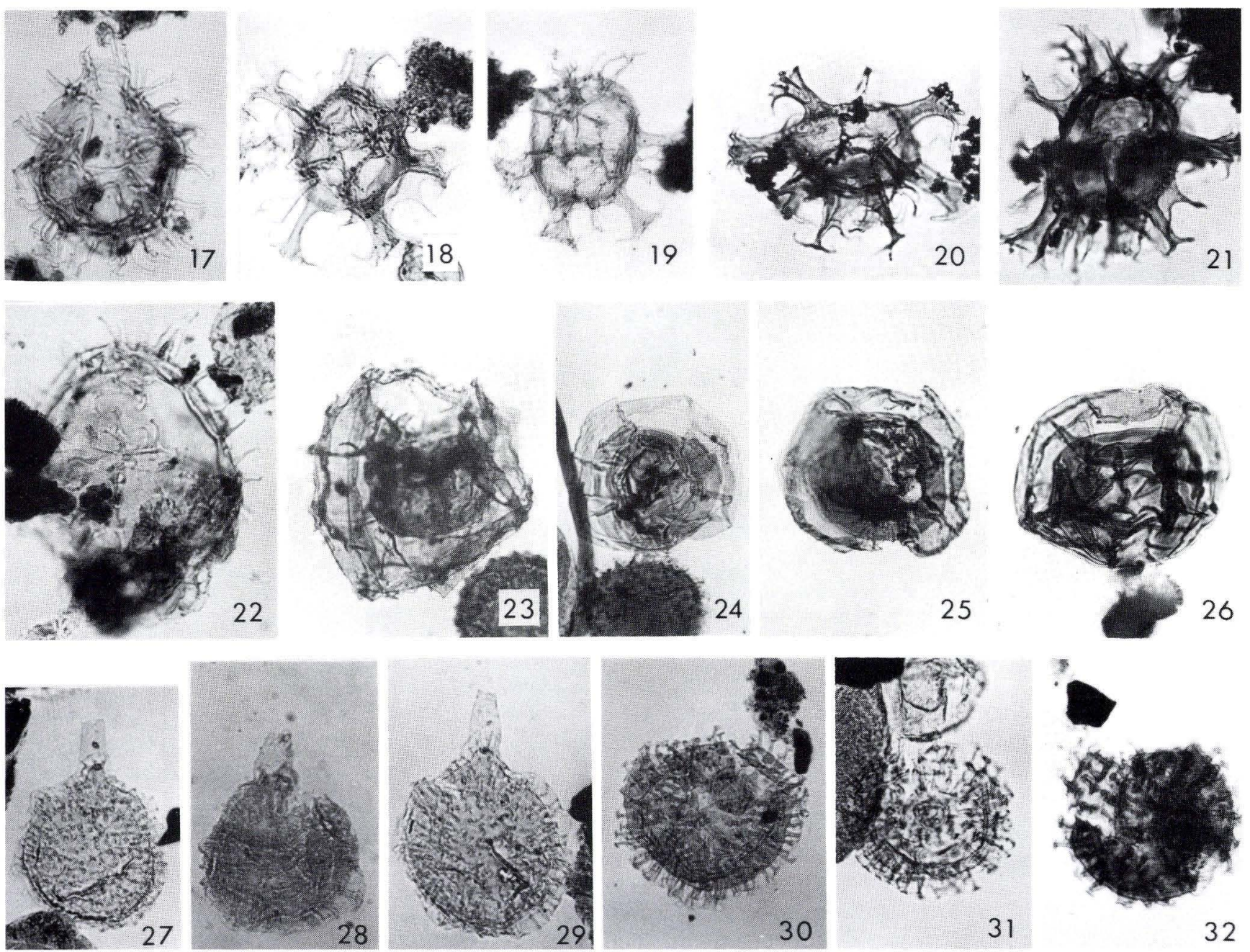
PLATE 13

All magnifications $\times 500$

Dingodinium cerviculum Cookson \& Eisenack, 1958

Fig. 1. Adda-1, 7710'.

Fig. 2. Adda-2, 7774'.

Fig. 3. I-1, $9960^{\prime}$

Fig. 4. I-1, 10410'

Fig. 5. Adda-1, 8460'.

Dingodinium jurassicum Cookson \& Eisenack, 1958

Fig. 6. Adda-1, 8430'.

Fig. 12. I-1, 10160'.

Dingodinium spinosum (Duxbury, 1977) Davey, 1979c

Fig. 7. Adda-1, 9000'.

Fig. 8. Adda-1, 9000'

Fig. 9. Adda-1, 9000'

Fig. 10. Adda-1, $8550^{\prime}$

Fig. 11. I-1, 10890'.

Dingodinium tuberosum (Gitmez, 1970) Fisher \& Riley, 1980 Fig. 13. I-1, 10410'.

Protoellipsodinium clavulum Davey \& Verdier, 1971

Fig. 14. I-1, 9400'

Fig. 15. I-1, 9380'

Fig. 16. I-1, 9524'

Protoellipsodinium spinosum Davey \& Verdier, 1971 Fig. 17. I-1, 9490'

Fig. 18. Same specimen as in fig. 17.

Prolixosphaeridium parvispinum (Deflandre, 1937b) Davey et al., 1969

Fig. 19. I-1, 9460'

Fig. 20. Adda-1, $7650^{\prime}$.

Fig. 21. I-1, 10090'

aff. Bourkidinium granulatum Morgan, 1975

Fig. 22. Adda-1, 7870'

Fig. 23. Adda-1. $7940^{\prime}$

Fig. 24. I-1, 10770'.

Kiokansium polypes (Cookson \& Eisenack, 1962b) Davey, 1979b

Fig. 25. I-1, 9420'.

Fig. 26. I-1, 9420'

Fig. 27. I-1, 9490'.

Coronifera oceanica Cookson \& Eisenack, 1958

Fig. 28. Adda-2, 7753'3'".

Fig. 29. Adda-2, $7753^{\prime} 3^{\prime \prime}$. 

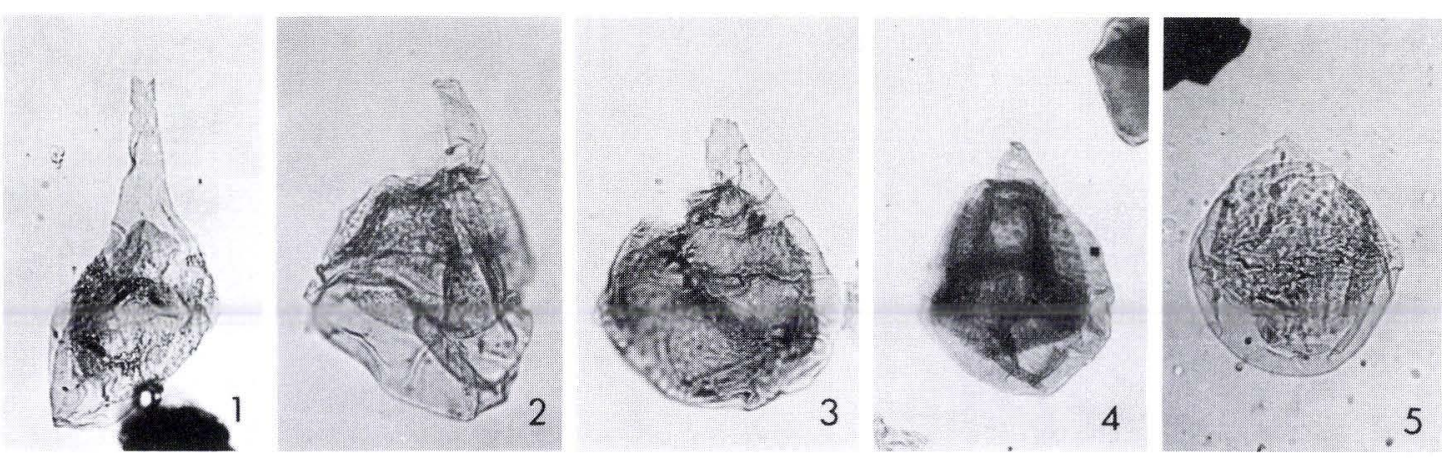

I
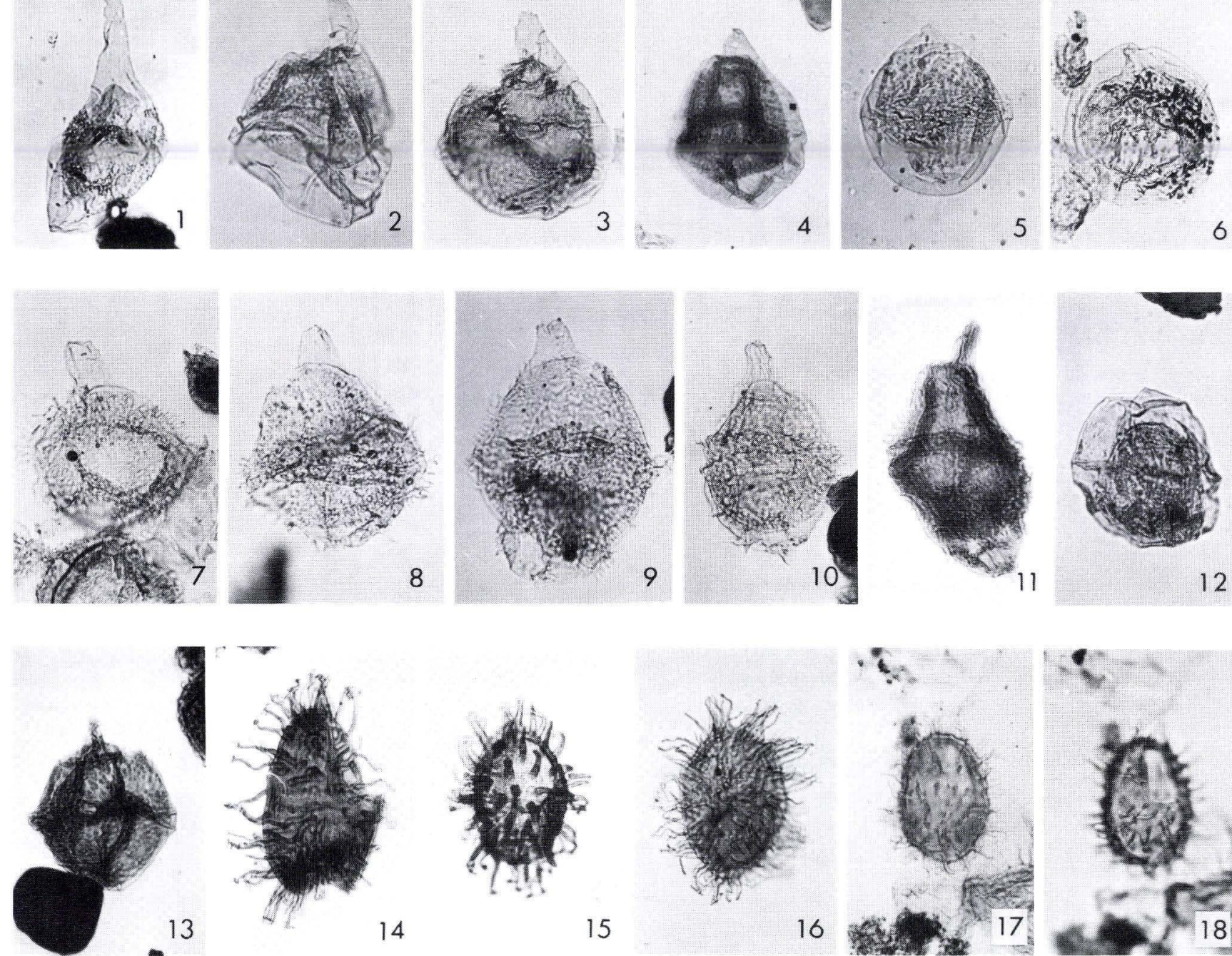

5

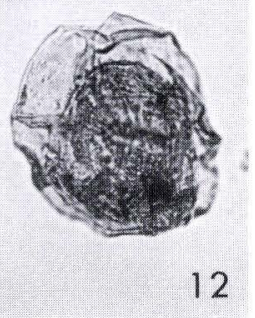

12
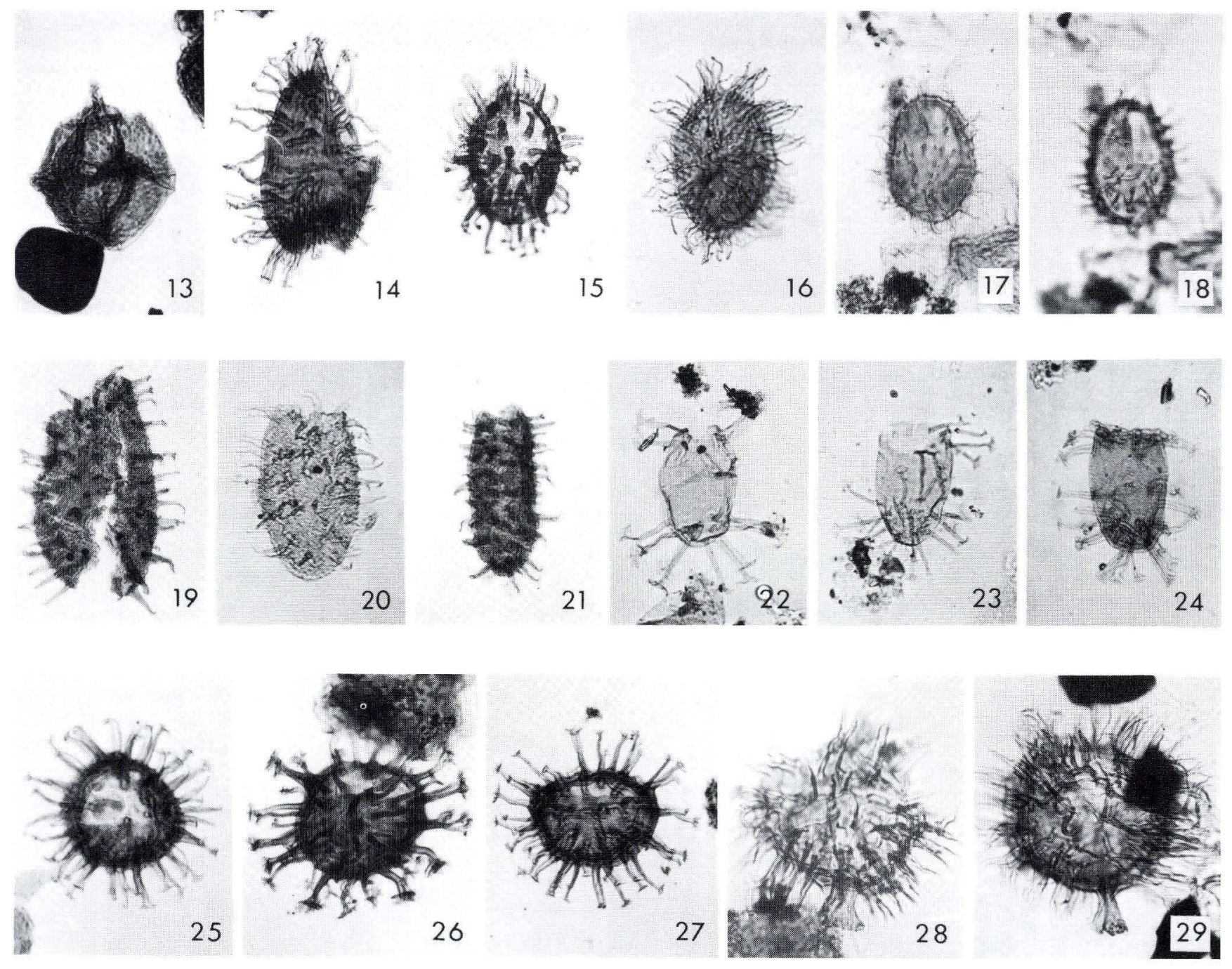
PLATE 14

All magnifications $\times 500$

Dapsilidinium multispinosum (Davey, 1974) Bujak et al., 1980

Fig. 1. Adda-1, $8850^{\prime}$.

Fig. 2. I-1, 9490'

Fig. 3. I-1, 9900'.

Litosphaeridium siphoniphorum (Cookson \& Eisenack, 1958) Davey \& Williams, 1966b

Fig. 4. Adda-1, 7540'.

Litosphaeridium arundum (Eisenack \& Cookson, 1960) Davey, $1979 \mathrm{~b}$

Fig. 5. Adda-1, 7530'.

Egmontodinium torynum (Cookson \& Eisenack, 1960b) Davey, $1979 \mathrm{c}$

Fig. 6. Adda-1, $8600^{\prime}$.

Fig. 7. I-1, 10850'.

Fig. 8. I-1, 10890'.

Systematophora cf. areolata sensu Davey, 1982a

Fig. 9. Adda-1, 8460'.

Fig. 21. I-1, 10970'.

Egmontodinium expiratum Davey, 1982a

Fig. 10. A specimen transitional to Egmontodinium torynum. I- $1,10850^{\prime}$.

Fig. 11. Adda-1, 8700'.

Fig. 12. Adda-1, $9150^{\prime}$.

Fig. 13. I-1, 10850'.

Egmontodinium polyplacophorum Gitmez \& Sarjeant, 1972 Fig. 14. M-8, 7800'.

Surculosphaeridium sp. III Davey, 1982a

Fig. 15. M-8, 7400'.

Fig. 16. I-1, 10570'.

Fig. 17. Adda-1, 7910'.

Surculosphaeridium sp. II Davey, 1982a

Fig. 18. I-1, 10570'.

cf. Surculosphaeridium sp. I Davey, 1982a

Fig. 19. Incomplete specimen. Adda-1, 7940'.

Cymososphaeridium validum Davey, 1982a Fig. 20. I-1, 10290'.

Systematophora complicata Neale \& Sarjeant, 1962 Fig. 22. I-1, 9900'. 
PLATE 14
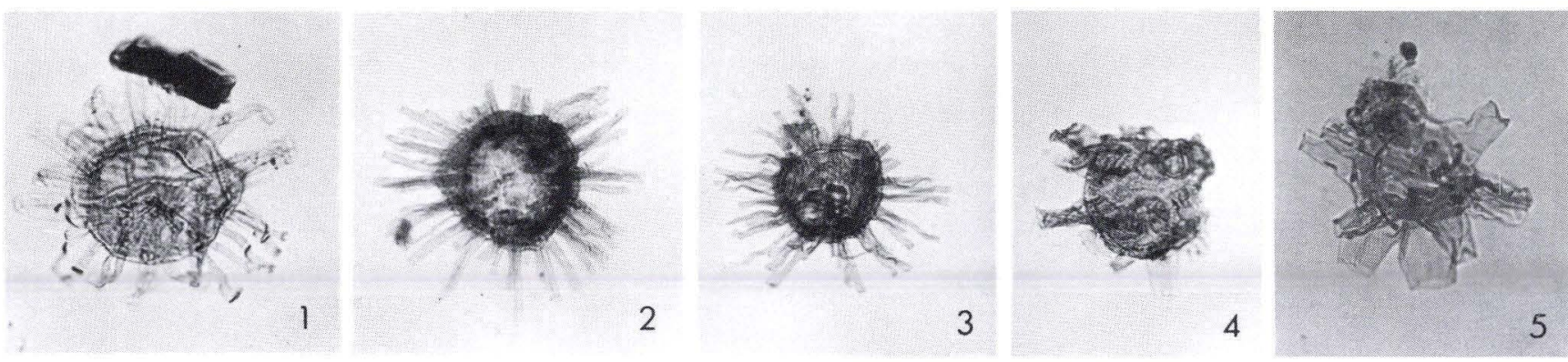

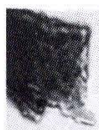

\section{$\odot$} ก. (3)
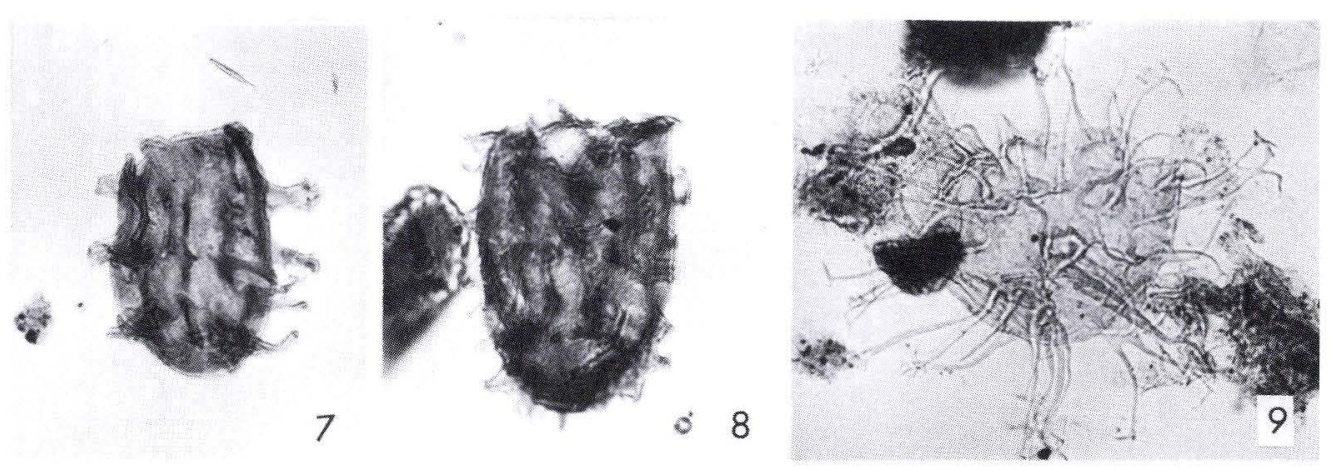

Crax
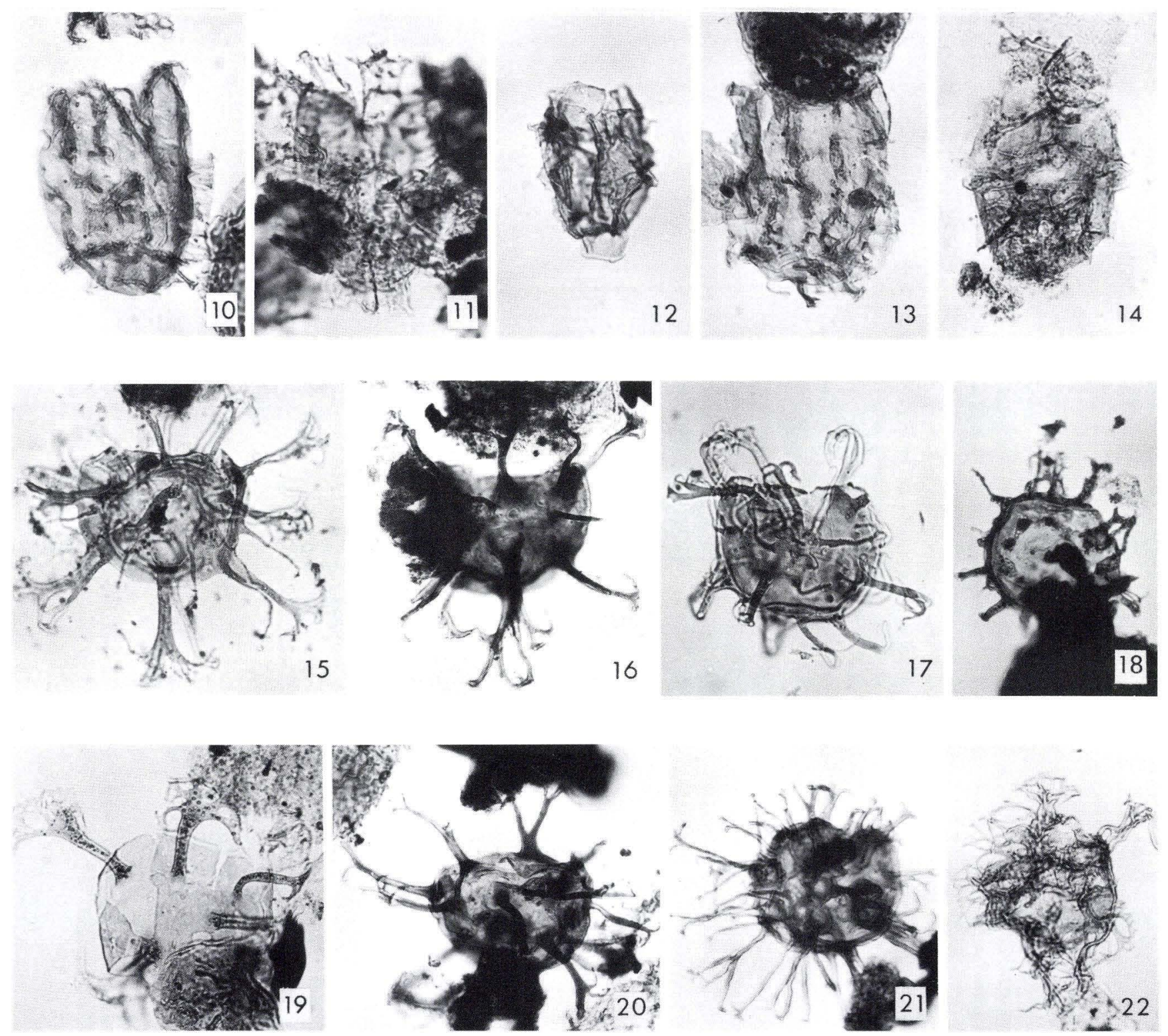
PLATE 15

All magnifications $\times 500$

Oligosphaeridium prolixispinosum Davey \& Williams, 1966b Fig. 1. I-1, 9340'

Oligosphaeridium sp. GE McIntyre \& Brideaux, 1980

Fig. 2. Adda-1, 8700'

Oligosphaeridium sp. 1

Fig. 3. I-1, 9850'

Oligosphaeridium diluculum Davey, 1982a

Fig. 4. E-1, 9720'.

Oligosphaeridium asterigerum (Gocht, 1959) Davey \& Williams, 1966b

Fig. 5. I-1, $9850^{\prime}$

Fig. 6. Adda-1, 7850'

Oligosphaeridium complex (White, 1842) Davey \& Williams, 1966b

Fig. 7. I-1, 10020'

Fig. 10. Adda-2, 7762'

Stiphrosphaeridium anthophorum (Cookson \& Eisenack, 1958) Davey, 1982a

Fig. 8. Adda-2, 7774'

Fig. 9. Adda-1, 8600'

Stiphrosphaeridium arbustum Davey, 1982a

Fig. 11. Adda-1, 8600'.

Stiphrosphaeridium dictyophorum (Cookson \& Eisenack, 1958) Davey, 1982a

Fig. 12. I-1, 9420'.

Fig. 13. I-1, 10020'.

Hystrichosphaerina schindewolfii Alberti, 1961

Fig. 14. A single, simple paracingular process is visible. E-1, $8191^{\prime} 6^{\prime \prime}$.

Hystrichosphaeridium scoriaceum Raynaud, 1978

Fig. 15. Adda-1, 7980'

Fig. 16. Adda-1, 7980'

Fig. 17. I-1, 10290'.

Fig. 18. I-1, 10810'. 
PLATE 15


(2)

PLATE 16

All magnifications $\times 500$

Kleithriasphaeridium eoinodes (Eisenack, 1958) Davey, 1974 Fig. 1. Adda-1, 7800'.

Fig. 2. I-1, 9510'

Fig. 3. I-1, 10220'.

Fig. 4. I-1, 10530',

Kleithriasphaeridium corrugatum Davey, 1974 Fig. 5. Adda-1, 9150'.

Fig. 6. I-1, 9490'.

Kleithriasphaeridium cf. corrugatum Davey, 1974

Fig. 7. Adda-2, 7774'.

Kleithriasphaeridium fasciatum (Davey \& Williams, 1966b) Davey, 1974

Fig. 8. E-1, 9720'.

Fig. 13. Adda-1, 9000'.

Kleithriasphaeridium porosispinum Davey, 1982a

Fig. 9. Adda-1, 8800'.

Fig. 10. M-8, 7800'.

Fig. 11. Adda-1, 9150'.

Kleithriasphaeridium sp. 1.

Fig. 12. I-1, 10710'.

Fig. 17. I-1, 10220'.

Florentinia laciniata Davey \& Williams, 1973

Fig. 14. Adda-2, 7762'.

Florentinia mantellii (Davey \& Williams, 1966) Davey \& Verdier, 1973

Fig. 15. A specimen transitional to Florentinia cooksoniae. Adda-2, 7762'.

Fig. 16. A specimen transitional to Florentinia cooksoniae. Adda-1, 7640'.

Fig. 18. I-1, 9780'

Fig. 19. I-1, 9460'.

Florentinia cooksoniae (Singh, 1971) Duxbury, 1980

Fig. 20. I-1, 9420'.

Fig. 21. I-1, 9850'. 


PLATE 17

By Tove Birkelund

Figs. 1a-c Simbirskites sp. Part of body chamber and last chambers of phragmocone are preserved, showing the characteristic

Simbirskites ribbing pattern and suture pattern.

Note the embedding of the ammonite in a debris flow horizon. Fig. 1c slightly reduced. Adda-2, core 3, 7812 ${ }^{\prime} 2^{\prime}-7813^{\prime}$. Upper Hauterivian.

Figs. 2a-b Simbirskites (Craspedodiscus) cf. gottschei (v. Koenen). Adda-2, core 4, 7833' - 7833 $\frac{12^{\prime}}{}$. The species is known from Bed C4L of Speeton Clay, belonging to the gottschei Zone of the Upper Hauterivian (see Rawson 1971). 

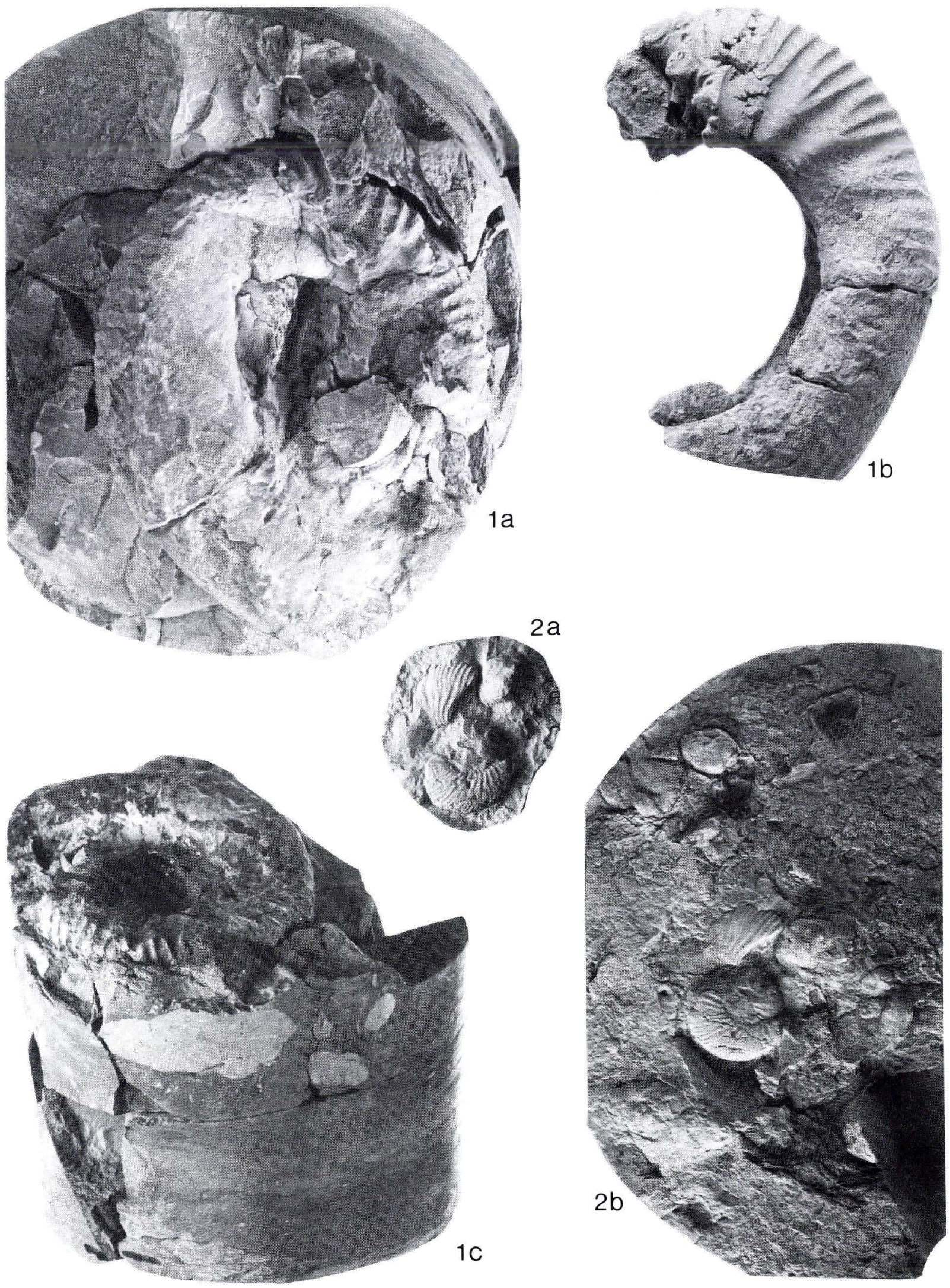
This paper documents the age of the formations and seismostratigraphic units of the North Sea Central Trough. All six Lower Cretaceous stages are shown to be present in the area.

The ages are interpreted on the basis of the author's study of dinoflagellates, which are fully illustrated in photographic plates.

The analysis also includes a revised distribution chart of dinoflagellates in the Lower Cretaceous of NW-Europe. 